Prepared in cooperation with the Minnesota Department of Natural Resources

\title{
Water-Quality Models to Assess Algal Community Dynamics, Water Quality, and Fish Habitat Suitability for Two Agricultural Land-Use Dominated Lakes in Minnesota, 2014
}

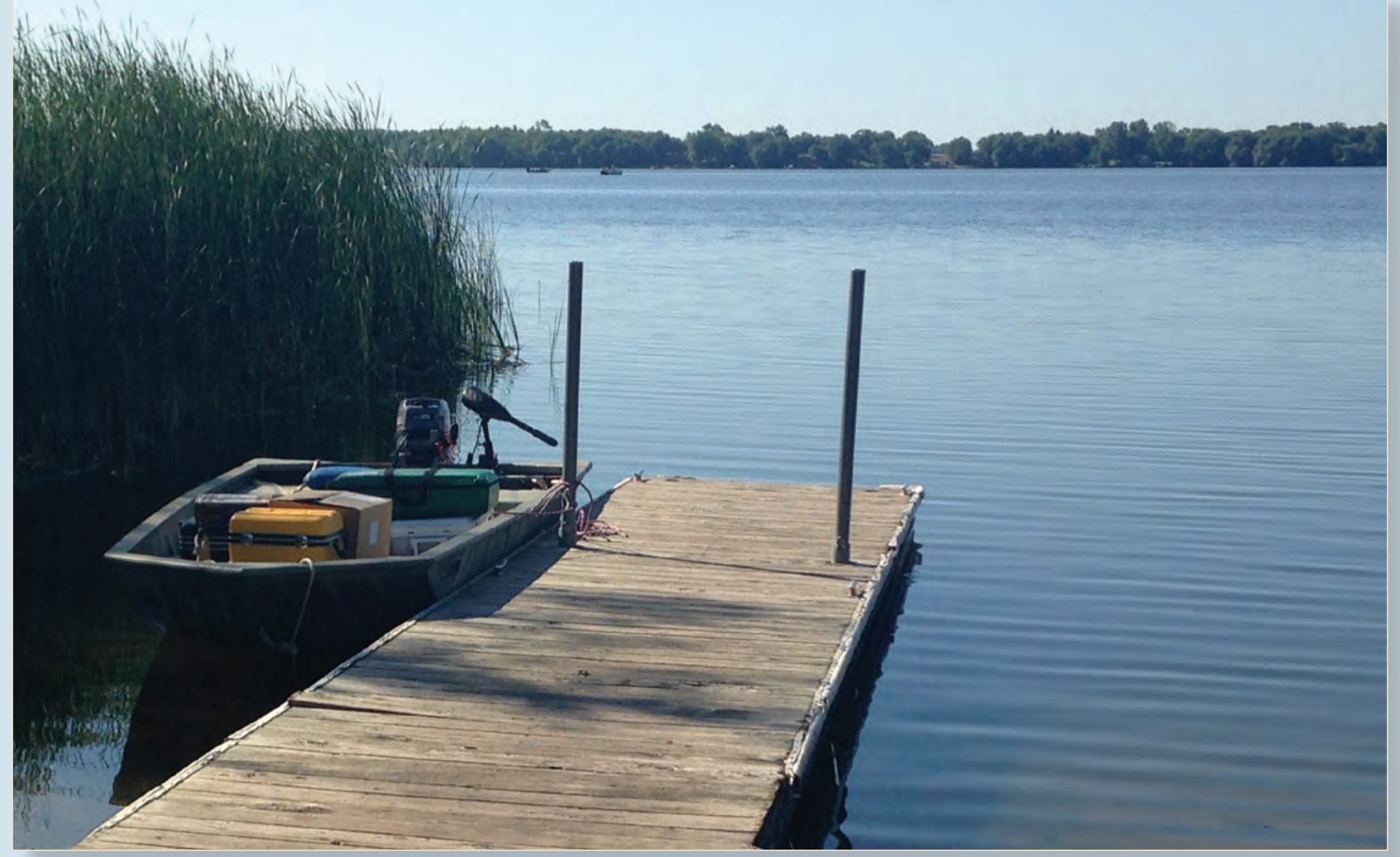

Scientific Investigations Report 2017-5056 
Front cover. Pearl Lake north shoreline at the public boat access, looking south across Pearl Lake, Minnesota, July 2015. Photograph by Les Warren, St. Cloud State University.

Back cover. Pearl Lake, Minnesota, May 2016. Photograph by Les Warren, St. Cloud State University. 


\section{Water-Quality Models to Assess Algal Community Dynamics, Water Quality, and Fish Habitat Suitability for Two Agricultural Land-Use Dominated Lakes in Minnesota, 2014}

By Erik A. Smith, Richard L. Kiesling, and Jeffrey R. Ziegeweid

Prepared in cooperation with the Minnesota Department of Natural Resources

Scientific Investigations Report 2017-5056 


\title{
U.S. Department of the Interior \\ RYAN K. ZINKE, Secretary
}

\section{U.S. Geological Survey William H. Werkheiser, Acting Director}

\author{
U.S. Geological Survey, Reston, Virginia: 2017
}

For more information on the USGS - the Federal source for science about the Earth, its natural and living resources, natural hazards, and the environment-visit https://www.usgs.gov/ or call 1-888-ASK-USGS.

For an overview of USGS information products, including maps, imagery, and publications, visit https://store.usgs.gov.

Any use of trade, firm, or product names is for descriptive purposes only and does not imply endorsement by the U.S. Government.

Although this information product, for the most part, is in the public domain, it also may contain copyrighted materials as noted in the text. Permission to reproduce copyrighted items must be secured from the copyright owner.

Suggested citation:

Smith, E.A., Kiesling, R.L., and Ziegeweid, J.R., 2017, Water-quality models to assess algal community dynamics, water quality, and fish habitat suitability for two agricultural land-use dominated lakes in Minnesota, 2014: U.S. Geological Survey Scientific Investigations Report 2017-5056, 65 p., https://doi.org/10.3133/sir20175056.

ISSN 2328-0328 (online) 


\section{Acknowledgments}

Funding for this study was provided by a grant from the Environmental and Natural Resource Trust Fund of Minnesota to the Minnesota Department of Natural Resources and by the U.S. Geological Survey Cooperative Water Program. This report presents a compilation of information supplied by several agencies and individuals, mainly the Minnesota Department of Natural Resources and Minnesota Pollution Control Agency. Brian Herwig, Eric Katzenmeyer, and Jeff Reed of the Minnesota Department of Natural Resources are acknowledged for support of this study, primarily by providing the compiled data throughout the study. Lee Engel of the Minnesota Pollution Control Agency provided profile data and water-quality sampling protocols.

Laura Hubbard and Norman Buccola of the U.S. Geological Survey are greatly acknowledged for technical reviews of the report. 


\section{Contents}

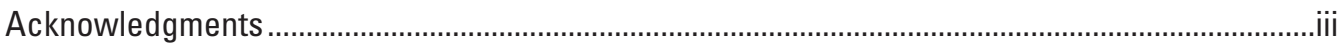

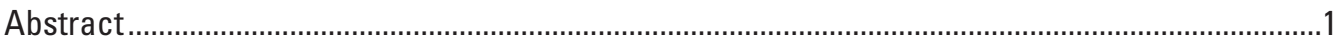

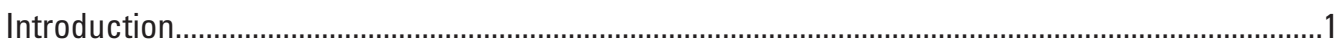

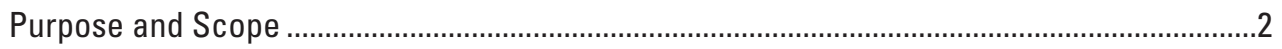

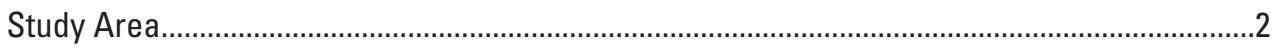

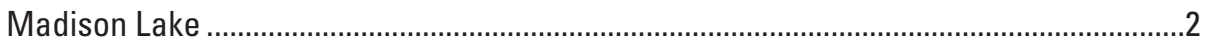

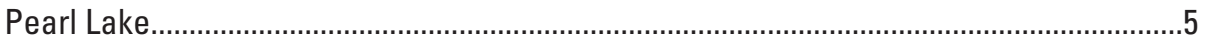

Previous Studies ................................................................................................................

Development of Water-Quality Models to Assess Algal Community Dynamics and

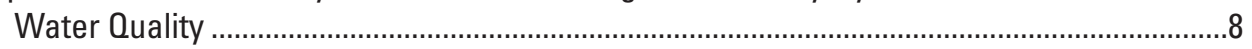

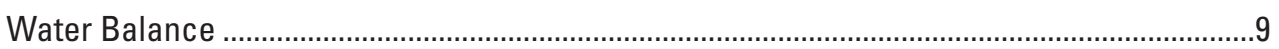

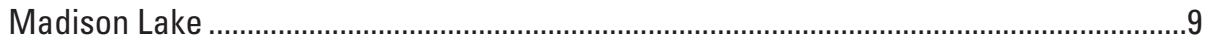

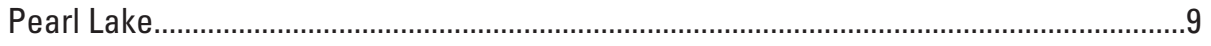

Bathymetric Data and Computational Grid ..........................................................................

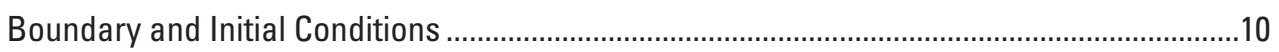

Hydraulic and Thermal Boundary Conditions ............................................................11

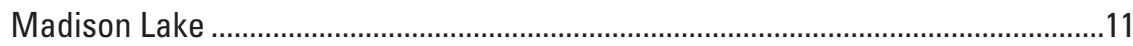

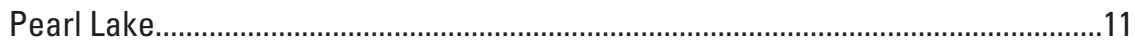

Water-Quality, Data Collection, Vertical Profiles, and Laboratory Analyses...................12

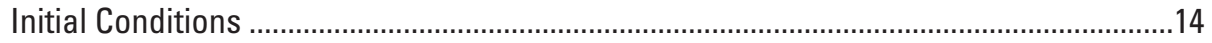

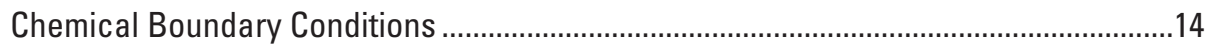

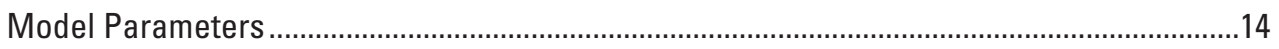

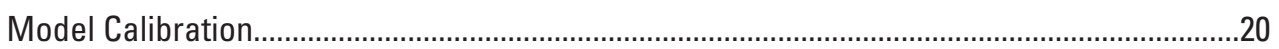

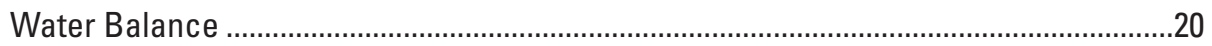

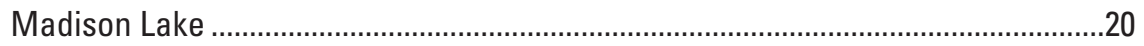

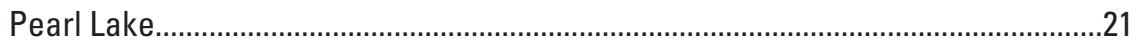

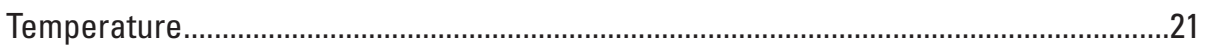

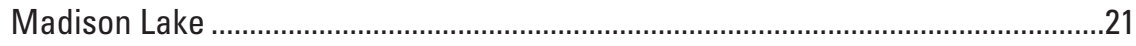

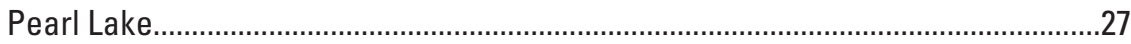

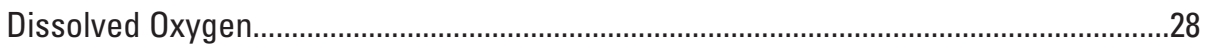

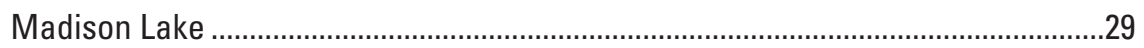

Pearl Lake..........................................................................................................

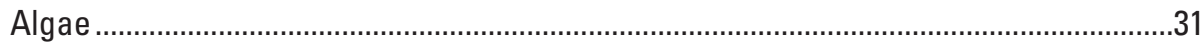

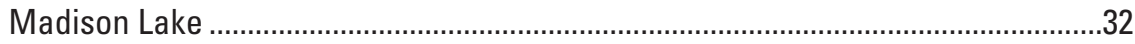

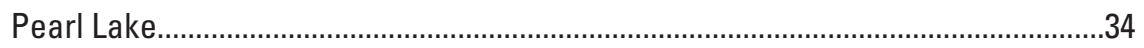

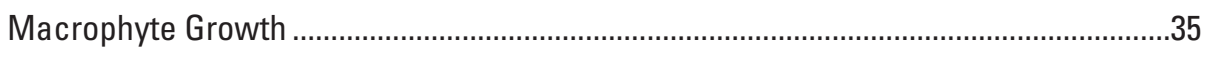

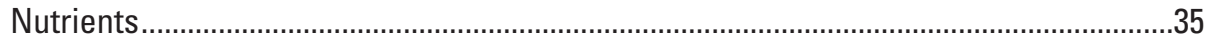

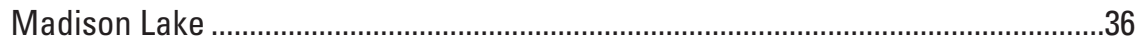

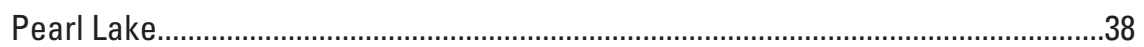

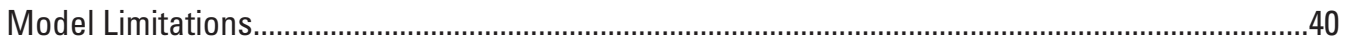

Fish Habitat Suitability for Cool-Water and Warm-Water Species ..................................................41

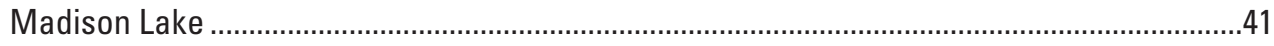

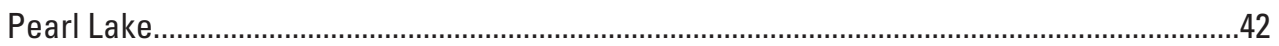




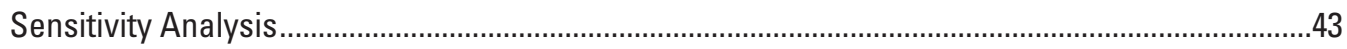

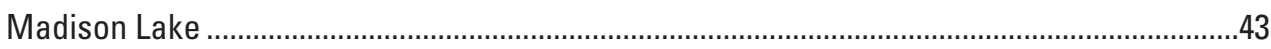

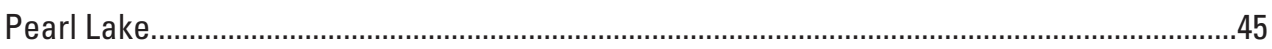

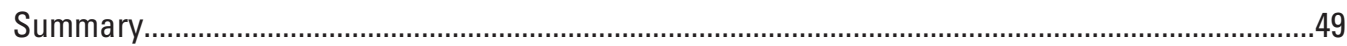

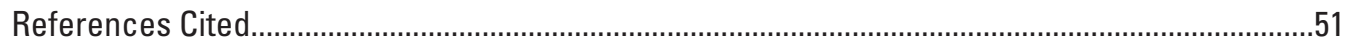

Appendix 1. Elevation-Streamflow Ratings, Unit Value Streamflows, and Daily Mean Streamflows for Madison Lake Inflow and Outflow Sites............................................58

Appendix 2. Relative Counts and Converted Algal Biomass for Madison Lake, Minnesota, and Pearl Lake, Minnesota.

\section{Figures}

1. Map showing major ecoregions and locations of two lakes of this study (Madison Lake and Pearl Lake) and two other sentinel lakes

(Elk Lake and Trout Lake) from Smith and others (2014), Minnesota

2. Map showing location of water-quality sampling sites for Madison Lake,

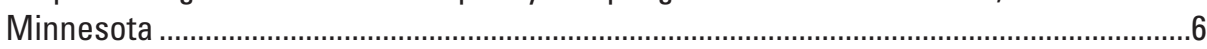

3. Map showing location of water-quality sampling sites for Pearl Lake, Minnesota ..........7

4. Graphs showing lake volume and lake-surface area compared to water-surface elevation for Madison Lake using the measured bathymetry and as represented by the model grid

5. Graphs showing lake volume and lake-surface area compared to water-surface elevation for Pearl Lake using the measured bathymetry and as represented by the model grid

6. Graph showing simulated and measured water-surface elevations for Madison Lake, May 15 to November 1, 2014.

7. Graph showing simulated and measured water-surface elevations for Pearl Lake, May 14 to November 13, 2014

8. Graph showing simulated and measured water temperature for the three different depths $(1,3$, and 4 meters) in the epilimnion at Madison Lake southwest deep point near Madison Lake, Minnesota, May 15 to November 1, 2014, with values of mean absolute error and root mean square error

9. Graph showing simulated and measured water temperature for the three different depths $(5.5,7$, and 9 meters $)$ in the transitional zone between the epilimnion and the hypolimnion at Madison Lake southwest deep point near Madison Lake, Minnesota, May 15 to November 1, 2014, with values of mean absolute error and root mean square error.

10. Graph showing simulated and measured water temperature for the three different depths $(11,13$, and 16.5 meters $)$ in the hypolimnion at Madison Lake southwest deep point near Madison Lake, Minnesota, May 15 to November 1, 2014, with values of mean absolute error and root mean square error.

11. Graph showing simulated and measured water temperature for three different depths $(1,5$, and 9 meters) for the Madison Lake northeast deep point near Madison Lake, Minnesota, May 15 to July 23, 2014, with values of mean absolute error and root mean square error

12. Graphs showing simulated and measured water temperature for vertical profiles at Madison Lake southwest deep point near Madison Lake, Minnesota, for eight dates in 2014, with values of mean absolute error and root mean square error. 
13. Graph showing simulated and measured water temperature for the three different depths (1.6, 2.1, and 2.8 meters) in the shallow mixed layer at the Pearl Lake Deep Point near Marty, Minnesota, May 14 to November 13, 2014, with values of mean absolute error and root mean square error.

14. Graph showing simulated and measured water temperature for the three different depths (3.8, 4.8, and 5.4 meters) in the deep mixed layer at the Pearl Lake Deep Point near Marty, Minnesota, May 14, to November 13, 2014, with values of mean absolute error and root mean square error

15. Graphs showing simulated and measured water temperature for vertical profiles at Pearl Lake Deep Point near Marty, Minnesota, for six dates in 2014, with values of mean absolute error and root mean square error.

16. Graphs showing simulated and measured dissolved oxygen concentration for vertical profiles at Madison Lake southwest deep point near Madison Lake, Minnesota, for eight dates in 2014, with values of mean absolute error and root mean square error.

17. Graphs showing simulated and measured dissolved oxygen concentration for vertical profiles at Pearl Lake Deep Point near Marty, Minnesota, for six dates in 2014, with values of mean absolute error and root mean square error.

18. Graph showing simulated and measured algal group distributions (diatoms, green algae, blue-green algae, and flagellates) for the 2-meter depth at Madison Lake southwest deep point near Madison Lake, Minnesota, May 15 to November 1, 2014 ...

19. Graph showing simulated and measured chlorophyll a concentrations for the 2-meter depth at Madison Lake northeast deep point near Madison Lake, Minnesota, (segment 5) and Madison Lake southwest deep point near Madison Lake, Minnesota, (segment 7) in Madison Lake, May 15 to November 1, 2014 .....

20. Graph showing simulated and measured algal group distributions (diatoms, green algae, blue-green algae, and flagellates) for the 2-meter depth at Pearl Lake Deep Point near Marty, Minnesota, May 14 to November 13, 2014.

21. Graph showing simulated and measured chlorophyll a concentrations for the 2-meter depth at Pearl Lake Deep Point near Marty, Minnesota, May 14 to November 13, 2014, with values of mean absolute error and root mean square error

22. Graph showing simulated and measured dissolved ammonia concentrations at 2 meters below the water surface in model segment 7 containing the Madison Lake southwest deep point near Madison Lake, Minnesota, May 15 to November 1, 2014, with values of mean absolute error and root mean square error .

23. Graph showing simulated and measured dissolved nitrate plus nitrite concentrations at 2 meters below the water surface in model segment 7 containing the Madison Lake southwest deep point near Madison Lake, Minnesota, May 15 to November 1, 2014, with values of mean absolute error and root mean square error ..

24. Graph showing simulated and measured dissolved orthophosphate concentrations at 2 meters below the water surface in model segment 7 containing the Madison Lake southwest deep point near Madison Lake, Minnesota, May 15 to November 1, 2014, with values of mean absolute error and root mean square error ..

25. Graph showing simulated and measured total Kjeldahl nitrogen concentrations at 2 meters below the water surface in model segment 7 containing the Madison Lake southwest deep point near Madison Lake, Minnesota, May 15 to November 1, 2014 , with values of mean absolute error and root mean square error 
26. Graph showing simulated and measured total phosphorus concentrations at 2 meters and 16.5 meters below the water surface in model segment 7 containing the Madison Lake southwest deep point near Madison Lake, Minnesota, May 15 to November 1, 2014, with values of mean absolute error and root mean square error

27. Graph showing simulated and measured ammonia concentrations at 2 meters below the water surface in model segment 4 containing the Pearl Lake Deep Point near Marty, Minnesota, May 14 to November 13, 2014, with values of mean absolute error and root mean square error.

28. Graph showing simulated and measured nitrate plus nitrite concentrations at 2 meters below the water surface in model segment 4 containing the Pearl Lake Deep Point near Marty, Minnesota, May 14 to November 13, 2014, with values of mean absolute error and root mean square error.....

29. Graph showing simulated and measured orthophosphate concentrations at 2 meters below the water surface in model segment 4 containing the Pearl Lake Deep Point near Marty, Minnesota, May 14 to November 13, 2014, with values of mean absolute error and root mean square error.

30. Graph showing simulated and measured total Kjeldahl nitrogen concentrations at 2 meters below the water surface in model segment 4 containing the Pearl Lake Deep Point near Marty, Minnesota, May 14 to November 13, 2014, with values of mean absolute error and root mean square error

31. Graph showing simulated and measured total phosphorus concentrations at 2 meters and 4.5 meters below the water surface in model segment 4 containing the Pearl Lake Deep Point near Marty, Minnesota, May 14 to November 13, 2014, with values of mean absolute error and root mean square error

32. Graph showing good-growth (combined lower and upper ranges) and optimal growth habitat, by percentage of total lake volume, for cool-water fish in Madison Lake, May 15 to November 1, 2014.

33. Graph showing good-growth (combined lower and upper ranges) and optimal growth habitat, by percentage of total lake volume, for warm-water fish in Madison Lake, May 15 to November 1, 2014.

34. Graph showing good-growth (combined lower and upper ranges) and optimal growth habitat, by percentage of total lake volume, for cool-water fish in Pearl Lake, May 14 to November 13, 2014.

35. Graph showing good-growth (combined lower and upper ranges) and optimal growth habitat, by percentage of total lake volume, for warm-water fish in Pearl Lake, May 14 to November 13, 2014

36. Graph showing simulated algal group distributions (diatoms, green algae, blue-green algae, and flagellates) for the 2-meter depth at the Madison Lake southwest deep point near Madison Lake, Minnesota, May 15 to November 1, 2014, with a 20-percent increase in the wind sheltering coefficient and the baseline (calibrated) model ...........47

37. Graph showing simulated dissolved ammonia concentrations at 2 meters below the water surface in model segment 7 containing the Madison Lake southwest deep point near Madison Lake, Minnesota, May 15 to November 1, 2014, with a 20 -percent increase in the wind sheltering coefficient and the baseline (calibrated) model.

38. Graph showing simulated dissolved orthophosphate concentrations at 2 meters below the water surface in model segment 7 containing the Madison Lake southwest deep point near Madison Lake, Minnesota, May 15 to November 1, 2014, with a 20-percent decrease in the wind sheltering coefficient and the baseline (calibrated) model 
39. Graph showing simulated algal group distributions (diatoms, green algae, blue-green algae, and flagellates) for the 2-meter depth at Pearl Lake Deep Point near Marty, Minnesota, May 14 to November 13, 2014, with a 20-percent decrease in the wind sheltering coefficient and the baseline (calibrated) model.

40. Graph showing simulated algal group distributions (diatoms, green algae, blue-green algae, and flagellates) for the 2-meter depth at Pearl Lake Deep Point near Marty, Minnesota, May 14 to November 13, 2014, with a 20-percent increase in the wind sheltering coefficient and the baseline (calibrated) model.

41. Graph showing simulated ammonia concentrations at 2 meters below the water surface in model segment 4 containing the Pearl Lake Deep Point near Marty, Minnesota, May 14 to November 13, 2014, with a 20-percent increase in the wind sheltering coefficient and the baseline (calibrated) model.

\section{Tables}

1. Location of continuous pressure transducers, water-quality sondes, thermistors, and discrete water-quality measurements used for the development of model input or calibration of water temperature, dissolved oxygen, and water-quality constituents in the Madison Lake and Pearl Lake studies, Minnesota.

2. Water-quality methods for constituents analyzed in water samples from Madison Lake and Pearl Lake, 2014

3. Initial constituent concentrations for Madison and Pearl Lakes for the 2014 calibration runs

4. Model parameters used for the water-quality algorithms for Madison Lake and Pearl Lake

5. Summary of values of mean absolute error and root mean square error for calibration runs for Madison Lake and Pearl Lake.

6. Summary of sensitivity analysis for water temperature and dissolved oxygen, in percent change from calibration run, for the segment containing the Madison Lake southwest deep point near Madison Lake, Minnesota, and the segment containing Pearl Lake Deep Point near Marty, Minnesota

7. Summary of sensitivity analysis for the water-quality parameters of dissolved orthophosphate, dissolved ammonia, dissolved nitrate plus nitrite, dissolved oxygen, and total phosphorus

\section{Appendix Tables}

1-1. Elevation-streamflow ratings for gaged Madison Lake inflow and outflow sites ...........58

1-2. Daily mean streamflows for unnamed stream to Madison Lake at CR-48 near Madison Lake, Minnesota (USGS station 05320130), May-November 2014.

1-3. Daily mean streamflows for unnamed stream between Schoolhouse and Goolsby Lakes southeast of Madison Lake, Minnesota (USGS station 05320140), MayNovember 2014.

1-4. Daily mean streamflows for Madison Lake outlet to Mud Lake south of Madison Lake, Minnesota (USGS station 05320170), May-November 2014.

2-1. Summary of relative counts and converted algal biomass for Madison Lake and Pearl Lake, May-November 2014 


\section{Conversion Factors}

International System of Units to U.S. customary units

\begin{tabular}{lcl}
\hline \multicolumn{1}{c}{ Multiply } & By & \multicolumn{1}{c}{ To obtain } \\
\hline meter $(\mathrm{m})$ & Length & foot $(\mathrm{ft})$ \\
meter $(\mathrm{m})$ & 3.281 & inches (in.) \\
kilometer $(\mathrm{km})$ & 39.37 & mile (mi) \\
\hline \multicolumn{2}{c}{ Area } & square mile $\left(\mathrm{mi}^{2}\right)$ \\
\hline square kilometer $\left(\mathrm{km}^{2}\right)$ & 0.6215 & \\
\hline cubic meter $\left(\mathrm{m}^{3}\right)$ & 0.3861 & cubic foot $\left(\mathrm{ft}^{3}\right)$ \\
\hline & Volume & foot per year $(\mathrm{ft} / \mathrm{yr})$ \\
\hline meter per year $(\mathrm{m} / \mathrm{yr})$ & 35.31 & \\
\hline & Flow rate & British thermal unit per hour per \\
\hline watt per square $\mathrm{meter}\left(\mathrm{W} / \mathrm{m}^{2}\right)$ & 3.281 & square foot $\left(\mathrm{Btu} / \mathrm{hr} / \mathrm{ft}^{2}\right)$ \\
\hline
\end{tabular}

Temperature in degrees Celsius $\left({ }^{\circ} \mathrm{C}\right)$ may be converted to degrees Fahrenheit $\left({ }^{\circ} \mathrm{F}\right)$ as

$$
{ }^{\circ} \mathrm{F}=\left(1.8 \times{ }^{\circ} \mathrm{C}\right)+32 .
$$

Vertical coordinate information is referenced to the North American Vertical Datum of 1988 (NAVD 88), unless otherwise indicated.

Horizontal coordinate information is referenced to the North American Datum of 1983 (NAD 83).

Elevation, as used in this report, refers to distance above the vertical datum.

\section{Supplemental Information}

Concentrations of chemical constituents in water are given in either milligrams per liter (mg/L) or micrograms per liter ( $\mu \mathrm{g} / \mathrm{L})$. 


\section{Abbreviations}

$\begin{array}{ll}< & \text { less than } \\ \text { DEM } & \text { digital elevation model } \\ \text { DHEL } & \text { Department of Health Environmental Laboratory } \\ \text { DO } & \text { dissolved oxygen } \\ \text { GIS } & \text { geographic information system } \\ \text { HAB } & \text { harmful algal bloom } \\ \text { ID } & \text { identification number } \\ \text { lidar } & \text { light detection and ranging } \\ \text { MAE } & \text { mean absolute error } \\ \text { MNDNR } & \text { Minnesota Department of Natural Resources } \\ \text { NWIS } & \text { National Water Information System } \\ R^{2} & \text { coefficient of determination } \\ \text { RMSE } & \text { root mean square error } \\ \text { SLICE } & \text { Sustaining Lakes in a Changing Environment } \\ \text { SOD } & \text { sediment oxygen demand } \\ \text { USACE } & \text { U.S. Army Corps of Engineers } \\ \text { USAF } & \text { U.S. Air Force } \\ \text { USGS } & \text { U.S. Geological Survey } \\ \text { V4.0 } & \text { version 4.0 } \\ \text { WSC } & \text { wind sheltering coefficient }\end{array}$




\title{
Water-Quality Models to Assess Algal Community Dynamics, Water Quality, and Fish Habitat Suitability for Two Agricultural Land-Use Dominated Lakes in Minnesota, 2014
}

\author{
By Erik A. Smith, Richard L. Kiesling, and Jeffrey R. Ziegeweid
}

\section{Abstract}

Fish habitat can degrade in many lakes due to summer blue-green algal blooms. Predictive models are needed to better manage and mitigate loss of fish habitat due to these changes. The U.S. Geological Survey (USGS), in cooperation with the Minnesota Department of Natural Resources, developed predictive water-quality models for two agricultural landuse dominated lakes in Minnesota-Madison Lake and Pearl Lake, which are part of Minnesota's sentinel lakes monitoring program - to assess algal community dynamics, water quality, and fish habitat suitability of these two lakes under recent (2014) meteorological conditions. The interaction of basin processes to these two lakes, through the delivery of nutrient loads, were simulated using CE-QUAL-W2, a carbon-based, laterally averaged, two-dimensional water-quality model that predicts distribution of temperature and oxygen from interactions between nutrient cycling, primary production, and trophic dynamics.

The CE-QUAL-W2 models successfully predicted water temperature and dissolved oxygen on the basis of the two metrics of mean absolute error and root mean square error. For Madison Lake, the mean absolute error and root mean square error were 0.53 and 0.68 degree Celsius, respectively, for the vertical temperature profile comparisons; for Pearl Lake, the mean absolute error and root mean square error were 0.71 and 0.95 degree Celsius, respectively, for the vertical temperature profile comparisons. Temperature and dissolved oxygen were key metrics for calibration targets. These calibrated lake models also simulated algal community dynamics and water quality. The model simulations presented potential explanations for persistently large total phosphorus concentrations in Madison Lake, key differences in nutrient concentrations between these lakes, and summer blue-green algal bloom persistence.

Fish habitat suitability simulations for cool-water and warm-water fish indicated that, in general, both lakes contained a large proportion of good-growth habitat and a sustained period of optimal growth habitat in the summer, without any periods of lethal oxythermal habitat. For Madison and
Pearl Lakes, examples of important cool-water fish, particularly game fish, include northern pike (Esox lucius), walleye (Sander vitreus), and black crappie (Pomoxis nigromaculatus); examples of important warm-water fish include bluegill (Lepomis macrochirus), largemouth bass (Micropterus salmoides), and smallmouth bass (Micropterus dolomieu). Sensitivity analyses were completed to understand lake response effects through the use of controlled departures on certain calibrated model parameters and input nutrient loads. These sensitivity analyses also operated as land-use change scenarios because alterations in agricultural practices, for example, could potentially increase or decrease nutrient loads.

\section{Introduction}

The ecology and water quality of small lakes with a large proportion of agricultural land use in the drainage area are often controlled by nutrient dynamics (Sharpley and others, 1987; Daniel and others, 1998; Bennett and others, 2001). The large input of nitrogen and phosphorus into the receiving water body dominates the growth dynamics of phytoplankton and macrophyte communities (Xu and others, 2010; Paerl and Paul, 2012). Lakes with long lake residence times can become established as eutrophic, or even hypereutrophic, as a stable state because of the internal recycling of nutrients from sediments (Lerman, 1974). Small, shallow lakes in particular are vulnerable because of the large sediment contact area relative to lake volume. These shallow lakes, and even deeper lakes with large nutrient loading, are susceptible to habitat degradation from enhanced growth of algal blooms (Schindler, 2006).

In Minnesota, lakes are facing substantial risks from land-use change and climate change (Tong and Chen, 2002). Although improved management practices are being implemented on agricultural land, increased economic pressures towards high intensity row-crop agriculture challenges the paradigm of improving water quality (Harding and others, 1999; Dumanski and others, 2006). Lakes from across the State are threatened by current (2017) and legacy nutrients, so 
it is imperative to gain an understanding of lake responses to increased and decreased fluxes of nutrients. In recent years, water-resource scientists have been making the case for focused assessments and monitoring of "sentinel" systems (Jassby, 1998; Magner and Brooks, 2008, Williamson and others, 2008), which are more closely monitored and studied to assess how these stressors affect lakes long term. Lakes and their contributing drainage basins are complex, and development of a mechanistic understanding of the linkage between basin-based stressors and lake metabolism is best accomplished by taking a long-term, adaptive approach towards water-resource management (Magnuson and others, 1990). Intensive, detailed study of representative systems is critical to understanding cause and effect mechanisms, but an equally important need is to compare this detailed information to a broader set of similar systems. For the Minnesota Department of Natural Resources (MNDNR) Sustaining Lakes in a Changing Environment (SLICE) research program, these study design requirements are being met by coupling intensive, predictive modeling of a subset of "super sentinel" lakes with 24 Minnesota sentinel lakes distributed in a split-panel design of environmental monitoring that includes basic basin, water-quality, habitat, and fish indicators across a gradient of ecoregions, depths, and nutrient levels (McDonald, 2003).

The ability to simulate the effects of large-scale stressors (for example, basin land-use alterations or decadal climate changes) on lake ecosystems is a critical component of a proactive management plan for Minnesota lakes. Several regional and statewide lake modeling studies have illustrated the potential linkages between climate change, lake morphology, and reductions in fish habitat in the form of temperature and dissolved oxygen (DO) distributions for Minnesota and the north-central United States (for example, see summaries in Stefan and others, 1995, 1996; De Stasio and others, 1996; Fang and others, 1999, 2010; Jacobson and others, 2008; Jiang and others, 2012). These models have documented the relative importance of lake-basin geometry, ice-free season, thermal stratification, DO stratification, and wind-driven mixing to the development of sustainable fish habitat in deepwater lakes of the region; however, the potential trophic-dynamic response to simultaneous changes in land use and climate is less understood, as is the response of specific lakes to these historical and hypothetical changes. Questions also remain as to how the complex food webs that support fish guilds within these modeled systems will respond to the predicted physical changes in fish habitat (De Stasio and others, 1996).

The U.S. Geological Survey (USGS), in cooperation with the Minnesota Department of Natural Resources, developed predictive water-quality models for two agricultural land-use dominated lakes in Minnesota-Madison Lake and Pearl Lake, which are part of Minnesota's sentinel lakes monitoring program - to assess algal community dynamics, water quality, and fish habitat suitability of these two lakes (fig. 1; table 1) under recent (2014) meteorological conditions. The two selected lakes, Madison Lake and Pearl Lake, have abundant cool-water and warm-water fish communities but are located within active agricultural drainage basins. Both lakes have frequent summer blue-green algal blooms, as supported by the algal count data (PhycoTech, 2017). The chosen modeling framework for this study, CE-QUAL-W2 (Cole and Wells, 2015), is a two-dimensional, laterally averaged, hydrodynamic and water-quality model originally developed by the U.S. Army Corps of Engineers (USACE) and currently supported by Portland State University (Cole and Wells, 2015). The CE-QUAL-W2 model addresses the interaction between nutrient cycling, primary production, and trophic dynamics to predict responses in the distribution of temperature and oxygen in lakes, which was a primary goal of this study.

\section{Purpose and Scope}

The purpose of this report is to document the development of predictive models to assess algal community dynamics, water quality, and fish habitat suitability of two selected lakes (Madison Lake and Pearl Lake) in Minnesota under recent (2014) meteorological conditions. Both lakes are classified as supporting large cool-water and warm-water fish communities. The water-quality models were calibrated using data collected from April 2014 through November 2014. A sensitivity analysis was done to better understand model response to some of its most important parameters, including the wind sheltering coefficient (WSC), sediment release rates of phosphorus, sediment oxygen demand (SOD), and the extinction coefficients. The sensitivity analysis was also used as a surrogate for potential basin modifications, potentially due to changes in management practices, for constituents such as inflowing phosphorus, nitrogen, and organic matter.

\section{Study Area}

Two Minnesota lakes dominated by agricultural land use, classified as super sentinel lakes (Minnesota Department of Natural Resources, 2010), are the focus of this study: Madison Lake in Blue Earth County and Pearl Lake in Stearns County. Previous extensive characterization of both lakes and their drainage basins was done during the initial phase of SLICE (Lindon and others, 2010; Anderson and others, 2012) and was summarized into separate lake reports.

\section{Madison Lake}

Madison Lake (fig. 2) in Blue Earth County, Minnesota, is in the Le Sueur River Basin, part of the greater Minnesota River Basin (Lindon and others, 2010). Madison Lake is located on the boundary of the Western Corn Belt Plains and the North Central Hardwood Forests ecoregions (Soulard and others, 2014). Madison Lake was carved out during the last glaciation, and the area surrounding Madison Lake is made up of thick deposits of poorly drained loam soils derived from Des Moines lobe glacial tills (Lindon and others, 2010). Madison Lake is weakly dimictic, generally starting off as 


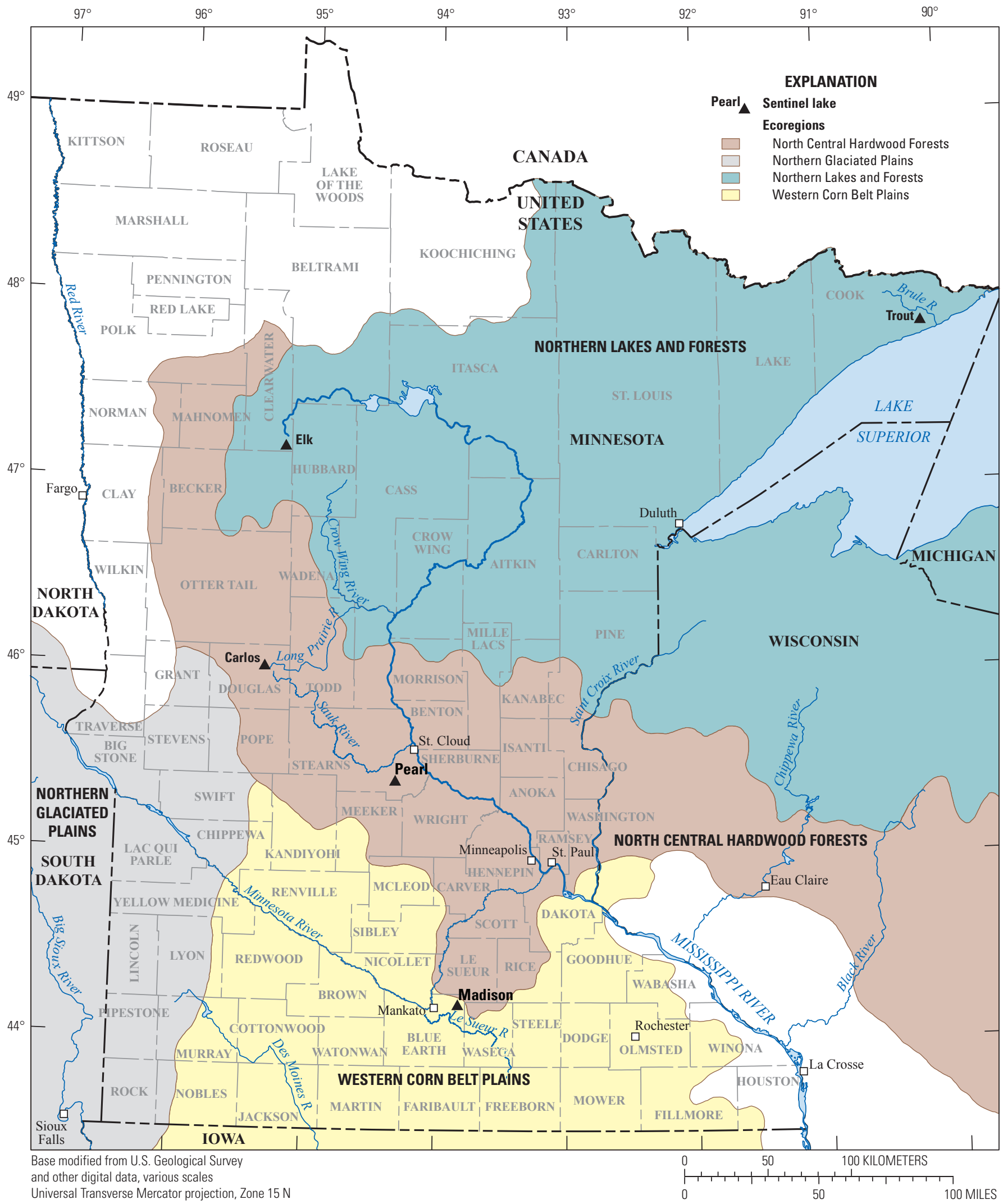

Figure 1. Major ecoregions and locations of two lakes of this study (Madison Lake and Pearl Lake) and two other sentinel lakes (Elk Lake and Trout Lake) from Smith and others (2014), Minnesota. 


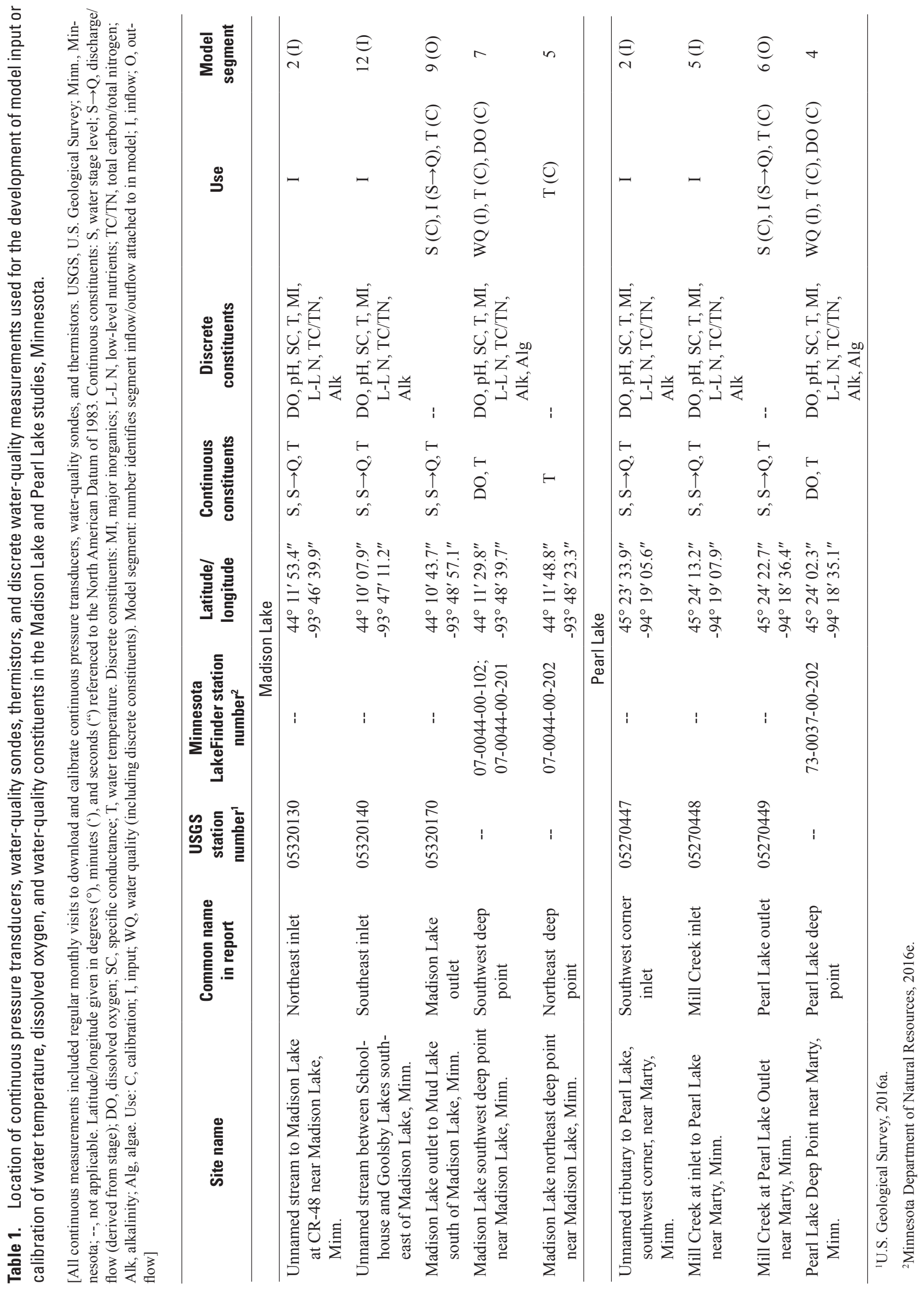


well-mixed before early summer, with a weak thermocline that develops in the summer months; the lake mixes again in the late fall (Lindon and others, 2010). Dissolved oxygen is well-mixed in the early spring (April to May) and late fall (mid-October), with a substantial portion of the hypolimnion becoming anoxic by mid-summer; however, anoxia can develop earlier in some years and subsist late into the fall, especially when the lake's thermocline develops early (Lindon and others, 2010). The water balance of the drainage basin for Madison Lake is typically controlled by a spring snowmelt in late March or early April, followed by periodic large rain events in the summer. Lake residence time is on the order of 3-4 years, with small surface-water inflow and outflow (Lindon and others, 2010). The mean precipitation in the region for 1981-2010 is 0.82 meter per year ( $\mathrm{m} / \mathrm{yr}$ ) (National Centers for Environmental Information, 2016a). Climate in the region has been known to consist of sustained drought periods, which can have a substantial effect on lake level. Lake levels decreased 3 meters (m) from 1939 to 1944 after a period of sustained drought and have been stable since that time. The lowest lake level recorded on Madison Lake was $305.71 \mathrm{~m}$ above the National Geodetic Vertical Datum of 1929 in May 1939 (Minnesota Department of Natural Resources, 2016a); the general water-level changes during the last 50 years have been within a narrow range of less than $(<) 1 \mathrm{~m}$.

Primary inflows to Madison Lake are located in the northeast and southeast parts of the lake, both of which were primary sampling locations during this study for nutrient and major inorganic constituents, continuous water temperature, and streamflow (table 1). The unnamed stream to Madison Lake at CR-48 near Madison Lake, Minn. (USGS station number 05320130 [U.S. Geological Survey, 2016a]; hereafter referred to as the "northeast inlet") flows into the relatively large and shallow northeast bay of Madison Lake; this is considered the primary inflow into the main water body for purposes of the CE-QUAL-W2 modeling. The unnamed stream between Schoolhouse and Goolsby Lakes southeast of Madison Lake, Minn. (USGS station number 05320140; hereafter referred to as the "southeast inlet") flows into the shallow part of the smallest bay (by area) along the southeast shoreline; this is considered the primary inflow into the secondary water body for purposes of the CE-QUAL-W2 modeling. The main primary outflow for Madison Lake is the site Madison Lake outlet to Mud Lake South of Madison Lake, Minn. (USGS station number 05320170 [U.S. Geological Survey, 2016a]; hereafter referred to as the "Madison Lake outlet"), located along the southwest part of the lake. Madison Lake has three other documented inlets, but these have intermittent flow and were not gaged for purposes of this study.

The lake has an area of 5.4 square kilometers $\left(\mathrm{km}^{2}\right)$ and a volume of 22.7 million cubic meters $\left(\mathrm{m}^{3}\right)$, with a maximum depth of $18 \mathrm{~m}$ (Lindon and others, 2010). The drainage basin of Madison Lake is $22.4 \mathrm{~km}^{2}$, for a small ratio of basin to lake area of $4: 1$. The lake has three distinct bays, with two of the three bays containing deep areas; the large and shallow bay is located in the northeast part of the lake (fig. 2). The deepest parts of the lake are close to one another and are near the shallow narrows between the northeast and southwest bays of the lake. The deep area in the southwest bay, also the largest deep area by areal extent, was sampled at site Madison Lake southwest deep point near Madison Lake, Minn. (hereafter referred to as "southwest deep point") with a depth of approximately $18 \mathrm{~m}$. This location was used for extensive in-lake water-quality sampling, periodic vertical profiles of water temperature and $\mathrm{DO}$, and continuous monitoring of water temperature at various depths. The other deep location, located in the northeast bay close to the shallow narrows, was sampled at site Madison Lake northeast deep point near Madison Lake, Minn. (hereafter referred to as "northeast deep point") with a depth of approximately $18 \mathrm{~m}$. This location was used primarily for continuous monitoring of water temperature at various depths.

\section{Pearl Lake}

Pearl Lake (fig. 3) in Stearns County, Minn., is in the Sauk River Basin, which is part of the greater Mississippi River Basin (Anderson and others, 2012). Pearl Lake is located within the North Central Hardwood Forests ecoregion (Soulard and others, 2014) in southeast Stearns County within a broad outwash plain that was deposited from the Des Moines lobe during the late Wisconsinan glaciation (Meyer and others, 1995). Based on the Stearns County quaternary stratigraphy map, Pearl Lake lies within more than $15 \mathrm{~m}$ of sand and gravel over two or more till beds (Meyer and others, 1995). Pearl Lake is an intermittently stratified polymictic lake, having a slight decline in temperatures earlier in the year, but is generally well-mixed before early summer through late fall (Anderson and others, 2012). Only a portion of the deeper mixed layer is anoxic earlier in the year, and by July, DO is wellmixed throughout the water column. The water balance of the basin for Pearl Lake is typically controlled by a spring snowmelt in late March or early April, followed by periodic large rain events in the summer. Lake residence time is on the order of 1-2 years, with small surface-water inflow and outflow (Anderson and others, 2012). The mean precipitation in the region for 1981-2010 is $0.70 \mathrm{~m} / \mathrm{yr}$ (National Centers for Environmental Information, 2016b). Climate in the region has been known to consist of sustained drought periods, although Pearl Lake has not shown the historical fluctuations that Madison Lake has shown. Intermittent lake-level measurements date back to 1946, with fluctuations of approximately $1.1 \mathrm{~m}$. The lowest lake level recorded on Pearl Lake was $339.94 \mathrm{~m}$ above the National Geodetic Vertical Datum of 1929 in September 1988 (Minnesota Department of Natural Resources, 2016b). 


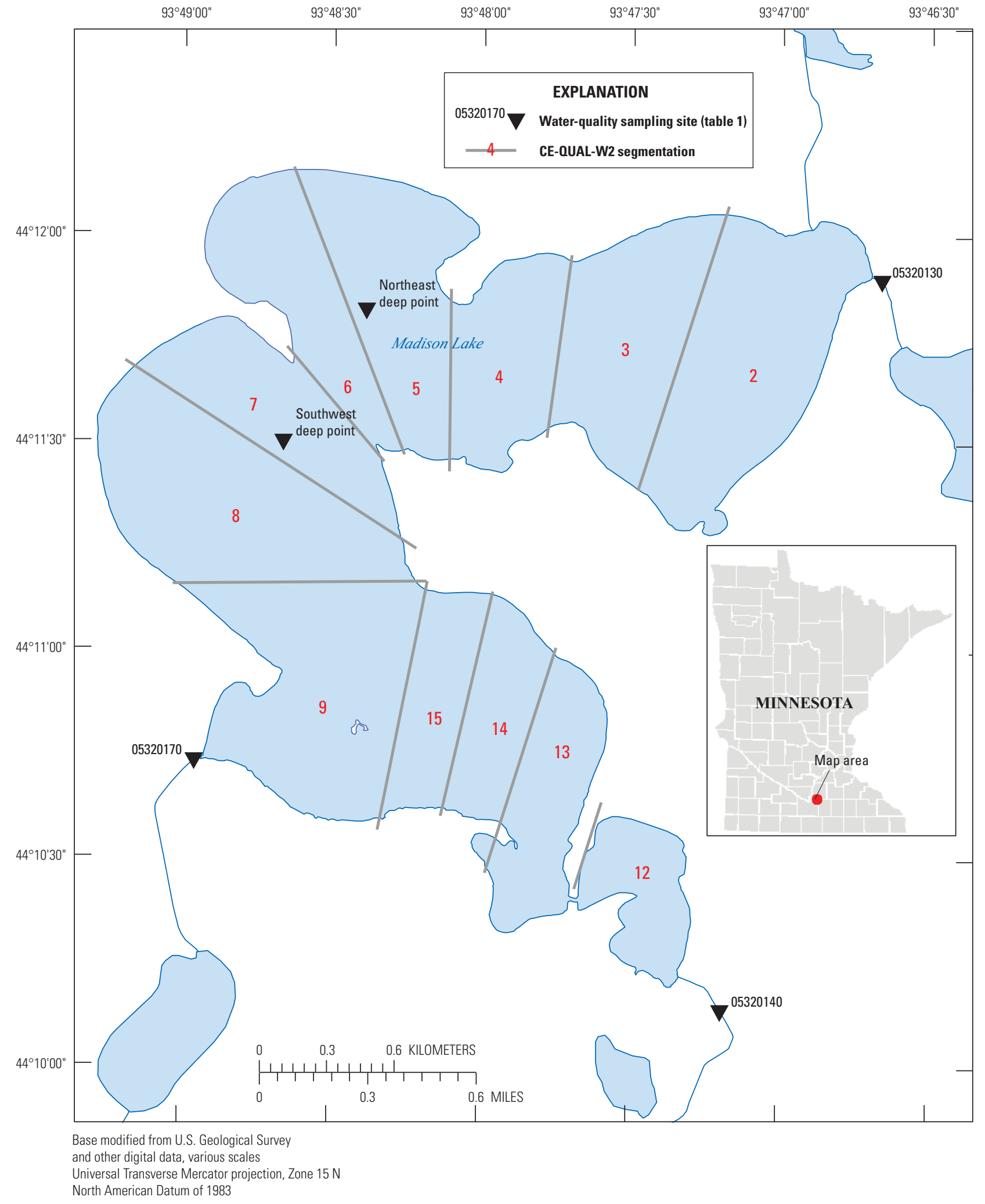

Figure 2. Location of water-quality sampling sites for Madison Lake, Minnesota. 


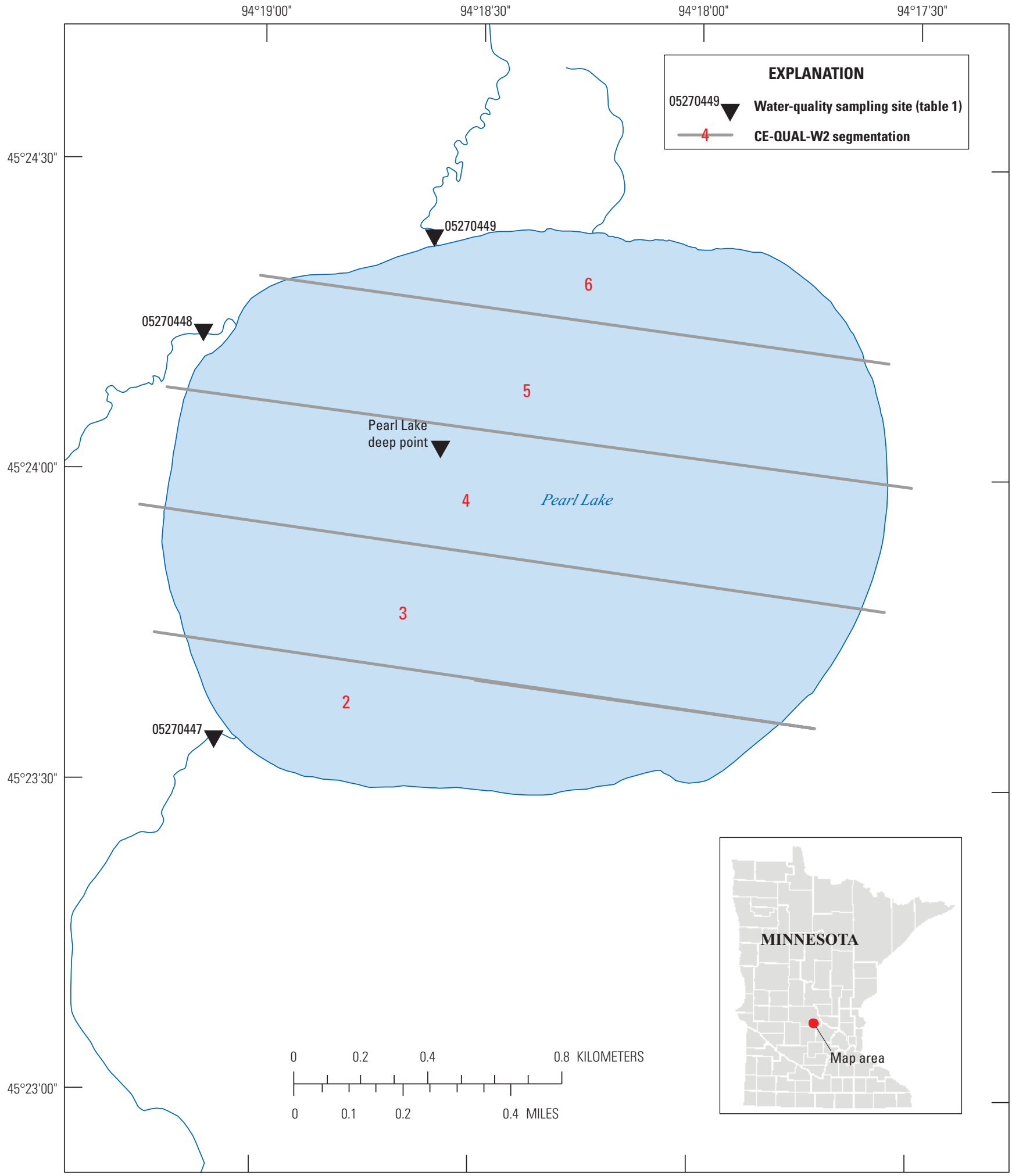

Base modified from U.S. Geological Survey and other digital data, various scales

Universal Transverse Mercator projection, Zone $15 \mathrm{~N}$

North American Datum of 1983

Figure 3. Location of water-quality sampling sites for Pearl Lake, Minnesota. 
Primary inflows to Pearl Lake are through the northwest and southwest parts of the lake, both of which were primary sampling locations during this study for nutrient and major inorganic constituents, continuous water temperature, and streamflow. The site unnamed tributary to Pearl Lake, southwest corner, near Marty, Minn. (USGS station number 05270447 [U.S. Geological Survey, 2016a]; hereafter referred to as the "southwest corner inlet") flows into the southwest corner of Pearl Lake; this is considered the primary inflow into the water body for purposes of the CE-QUAL-W2 modeling. The Mill Creek at inlet to Pearl Lake near Marty, Minn. (USGS station number 05270448 [U.S. Geological Survey, 2016a]; hereafter referred to as the "Mill Creek inlet") flows into the northwest corner of Pearl Lake; this is considered tributary inflow into the water body for purposes of the CEQUAL-W2 modeling. The main primary outflow for Pearl Lake is site Mill Creek at Pearl Lake outlet near Marty, Minn. (USGS station number 05270449 [U.S. Geological Survey, 2016a]; hereafter referred to as the "Pearl Lake outlet"), is along the north shoreline of the lake. No other inlets were documented for Pearl Lake.

Pearl Lake has an area of $3.0 \mathrm{~km}^{2}$ and a volume of 9.1 million $\mathrm{m}^{3}$, with a maximum depth of $5.5 \mathrm{~m}$ (Anderson and others, 2012). The Pearl Lake drainage basin is $40.0 \mathrm{~km}^{2}$, with a large ratio of basin to lake area of 24:1. The lake has a roughly oval shape, with the long axis oriented east to west (fig. 3). The lake has an extensive littoral area of 68 percent with deep areas in the middle of the lake. The deep area in the west central part of the lake was sampled at site Pearl Lake deep point near Marty, Minn. (hereafter referred to as "Pearl Lake deep point"), with a depth of approximately $5.5 \mathrm{~m}$. This location was used for extensive in-lake water-quality sampling, periodic vertical profiles of water temperature and $\mathrm{DO}$, and continuous monitoring of water temperature at various depths.

\section{Previous Studies}

Both Madison and Pearl Lakes have been extensively sampled as part of the sentinel lake studies. Water-quality (including nutrients and major ion chemistry), phytoplankton biomass, zooplankton biomass, and macrophyte surveys were all completed during portions of the intensive sampling years between 2006 and 2009. Data collection summaries for Madison Lake were documented in the Sentinel Lake Assessment Report for Madison Lake (Lindon and others, 2010). Long-term fish community surveys have been recorded and stored in the MNDNR long-term fisheries survey database species assessments, available on the LakeFinder website by lake name and county (Minnesota Department of Natural Resources, 2016c, 2016d). Madison Lake was included as part of a study of microcystin levels in eutrophic south-central Minnesota lakes by the Minnesota Pollution Control Agency (Lindon and Heiskary, 2007). Fish community integrity surveys were completed for both lakes following the methods of Drake and Pereira (2002). Pearl Lake was included in the potential future climate scenarios of cisco (Coregonus artedii) refuge lakes to assess potential cisco refugia, using the MINLAKE 2010 water-quality model (Fang and others, 2012).

\section{Development of Water-Quality Models to Assess Algal Community Dynamics and Water Quality}

Two lake models (one for Madison Lake and one for Pearl Lake) were constructed using CE-QUAL-W2, version 4.0 (V4.0) (Cole and Wells, 2015), which is a two-dimensional, laterally averaged, hydrodynamic and water-quality model originally developed by the USACE and currently supported by Portland State University (Cole and Wells, 2015). Because the model is laterally averaged, the model is best suited for water bodies with a fairly homogenous cross section. The CE-QUAL-W2 V4.0 model calculates the hydrodynamic properties of water-surface elevation, velocities, and temperature and can simulate 28 water-quality variables in addition to temperature. An advantage of the CE-QUAL-W2 model over other hydrodynamic and water-quality models is that the hydrodynamic and water-quality modules are coupled together through an equation of state for density, which is dependent on temperature, suspended solids, and dissolved solids. This enables the water-quality model to feed back into the hydrodynamic part of the model. Although the lateral averaging of the CE-QUAL-W2 model is better suited for long, narrow water bodies, such as reservoirs, rivers, and estuaries, the CE-QUAL-W2 model has been successfully applied in lake settings (Sullivan and Rounds, 2004; Sullivan and others, 2007; Smith and others, 2014). Although Madison Lake and Pearl Lake did not meet the same criterion of a long and narrow body, homogeneity in water-quality and water temperature data are indicated for both lakes such that laterally averaging did not seem to compromise the integrity of the model. Vertical variations captured with the CE-QUAL-W2 model are important for distinguishing temporal variations in the lake epilimnion, hypolimnion, and mixed layers. Initial calibration included a water balance based on water-surface elevation and continuous water temperature for each lake. Additional calibration targets included water temperature and DO depth profiles, in addition to discrete measurements of algae (chlorophyll $a$ ) and nutrients (ammonia, nitrate plus nitrite, total Kjeldahl nitrogen, total phosphorus, orthophosphate).

The individual lake models were developed in several phases. First, data were collected to determine the hydrological, thermal, and water-quality boundary conditions. A summary of the discrete and continuous constituents collected for both lakes, further split by sampling locations, is shown in table 1. Selection of the calibration year for both lakes was based on the most extensive datasets available, specifically for streamflow, water-surface elevation, and water temperature 
data, because these datasets were critical for driving the model hydrodynamics. All other data were aggregated to best define the initial boundary conditions. These data were also used later in the calibration process. Next, the model grid was constructed based on available lake bathymetry data (Minnesota Geospatial Information Office, 2016a). Datasets necessary to run the CE-QUAL-W2 model were formatted to fit the input data structure. Prior to initial water-balance calibration, input parameters were selected, mainly based on default values either prepopulated within the CE-QUAL-W2 model (Cole and Wells, 2015) or previous USGS CE-QUAL-W2 modeling efforts (Galloway and Green, 2006; Galloway and others, 2008; Smith and others, 2014).

\section{Water Balance}

The following subsections provide details of the waterbalance approach used for each of the lakes. The waterbalance approach for the lakes included an initial calibration followed by refined calibrations.

\section{Madison Lake}

The water balance of Madison Lake was calibrated for May 15-November 1, 2014, by comparing measured water levels to simulated water levels at the Madison Lake outlet (USGS station number 05320170), which is the main surfacewater outflow for Madison Lake (fig. 2; table 1). Two gaged inflow tributaries, the northeast inlet (USGS station number 05320130) and the southeast inlet (USGS station number 05320140) (fig. 2; table 1), provided the continuous streamflow measurements (U.S. Geological Survey, 2016a) for the entire calibration period. Adjustments were made to the gains and losses in the distributed tributary flow, which lumps all ungaged inflow and groundwater interactions, until the mean absolute error (MAE) and root mean square error (RMSE) values were $<0.02 \mathrm{~m}$.

\section{Pearl Lake}

The water balance of Pearl Lake was calibrated for May 14-November 13, 2014, by comparing measured water levels to simulated water levels at the Pearl Lake outlet, which is the main surface-water outflow located at the north end of the lake. Two gaged inflow tributaries, the southwest corner inlet (USGS station number 05270447) and the Mill Creek inlet (USGS station number 05270448) (fig. 3; table 1), provided the continuous streamflow measurements (U.S. Geological Survey, 2016a) for the entire calibration period. Adjustments were made to the gains and losses in the distributed tributary flow, which lumps all ungaged inflow and groundwater interactions, until a reasonable water balance was attained. Similar to methods for Madison Lake, adjustments were made to the gains and losses in the distributed tributary flow until a reasonable water balance, as well as low MAE and RMSE values for lake-level elevation, could be achieved.

\section{Bathymetric Data and Computational Grid}

Information from a digital elevation model (DEM) (U.S. Geological Survey, 2016b) and available bathymetric data from 2014 (Minnesota Geospatial Information Office, 2016a) were used to generate bathymetric cross sections for the CE-QUAL-W2 model. Accurate model reconstruction is important given that this reconstruction is the finite-difference representation of the lake itself. This accuracy can be verified by comparisons between the measured bathymetry and model grid for the curves relating water-surface elevation and lake volume and curves relating water-surface elevation and lakesurface area for each of the lakes (figs. 4-5).

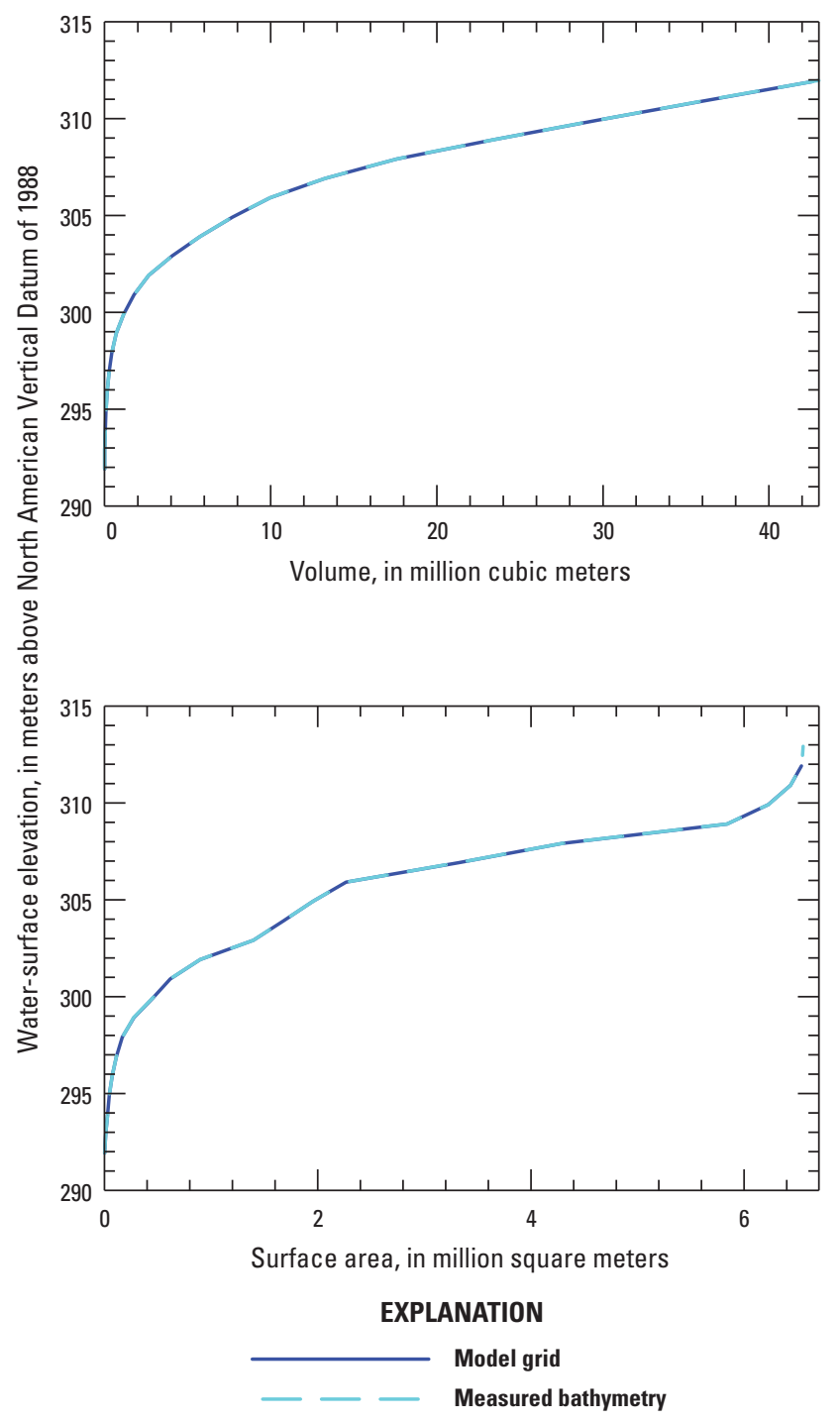

Figure 4. Lake volume and lake-surface area compared to water-surface elevation for Madison Lake using the measured bathymetry (Minnesota Geospatial Information Office, 2016a) and as represented by the model grid. 


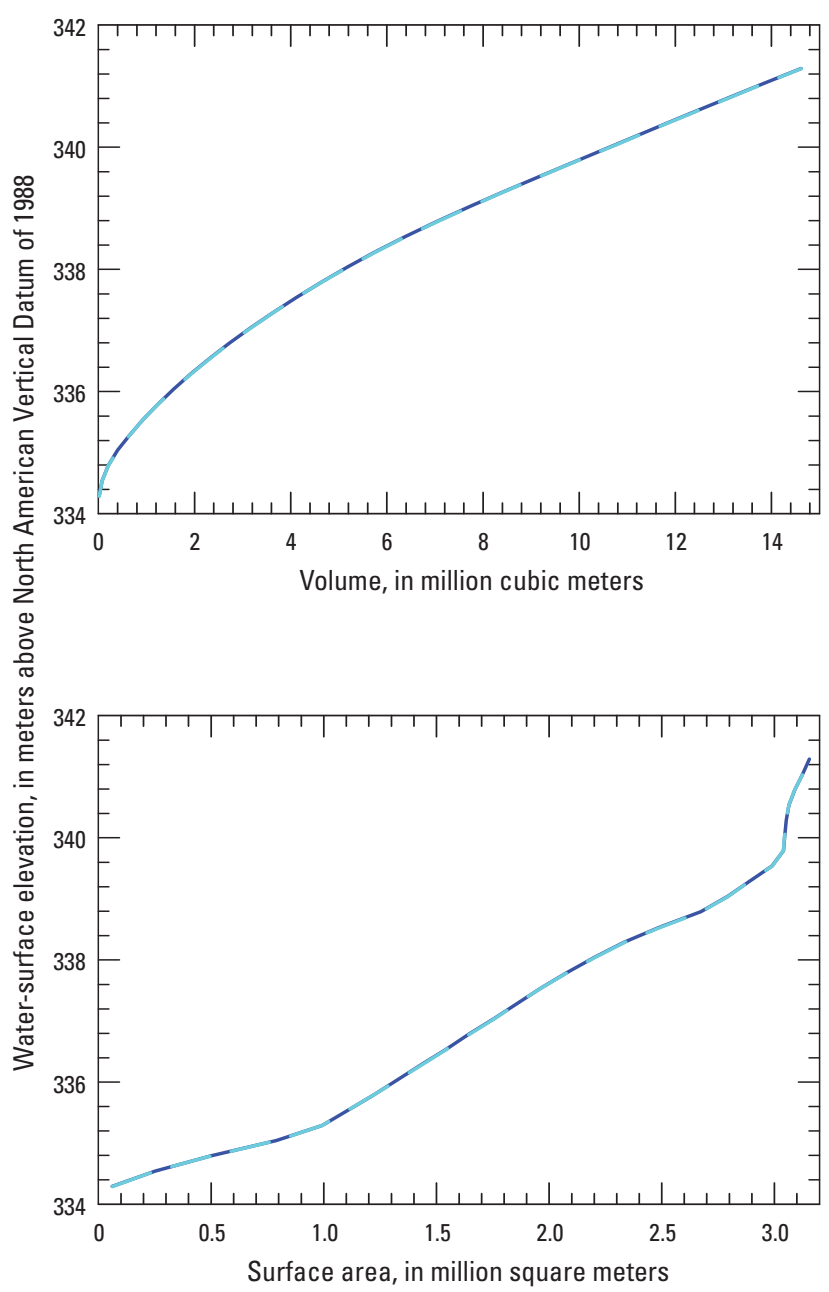

EXPLANATION

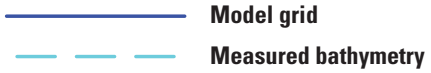

Figure 5. Lake volume and lake-surface area compared to water-surface elevation for Pearl Lake using the measured bathymetry (Minnesota Geospatial Information Office, 2016a) and as represented by the model grid.

The best available elevation data, 1-m DEMs based on light detection and ranging (lidar), were used to develop the area of potential inundation around the perimeter of both lakes (Minnesota Geospatial Information Office, 2016b) and merged with the bathymetric datasets. Bathymetric surveys of both lakes were available from the MNDNR as geographical information system (GIS) layers (Minnesota Geospatial Information Office, 2016a). The basic process was to combine the land elevation layer (1-m lidar DEM) with the bathymetric data to produce a gridded, three-dimensional model of the surface area and depth of each lake. The next step was to identify the deepest elevation value of the lake and then divide the lake model into 1-m slices starting at the bottom of the lake and ending approximately $2 \mathrm{~m}$ above the lake's base elevation (static water-level elevation); for Pearl Lake, the lake model was divided into $0.25-\mathrm{m}$ slices rather than $1-\mathrm{m}$ slices for numerical stability of the model due to its overall shallower depths. The base-lake elevation was obtained from lake-level data on the MNDNR Lake Finder website (Minnesota Department of Natural Resources, 2016a, 2016b). All model grid cells represented in each vertical section were identified and converted to a GIS polygon dataset. All slice polygons were then compiled into a single polygon GIS dataset, and the area of each polygon was calculated.

After completion of the GIS polygon dataset, each lake was divided into lateral segments (figs. 2-3). Within each lateral segment, vertical layers were drawn from the bottom of the lake up to $2 \mathrm{~m}$ above the static lake-level elevation. Distance along the longitudinal axis for individual CE-QUALW2 lateral segments varied considerably. Considerations for the number of segments selected included a balance between full-scale representation of the real structure of the lake and a segment structure that avoids numerical instability. Segments were grouped together into branches, with all of the branches grouped together representing the computational grid of the water body. The approximate segment boundaries for the CEQUAL-W2 two-dimensional computational grids are shown in figures 2 and 3. With the ability to use different branches to represent separate bays or embayments, the southeast part of Madison Lake (where the southeast inlet flows into the lake) was separated out as a second distinct branch that flows into segment 9 (fig. 2); branch 1 includes segments 2 through 9, and branch 2 includes segments 12 through 15. Pearl Lake was modeled as a single water body with 5 computational segments (fig. 3).

\section{Boundary and Initial Conditions}

The success of the model largely depended on a high data density of biological, chemical, and physical lake characteristics from which lake parameters could be calculated and the model could be calibrated. Several continuous flow and water-quality monitoring systems were installed to calculate the initial and boundary conditions for the models and to provide a robust calibration dataset. Streamflow was measured on a regular schedule according to methods described in Buchanan and Somers (1969) and Mueller and Wagner (2008). All streamflow measurements were done by the MNDNR, with initial training provided by USGS personnel; streamflow data are available from U.S. Geological Survey (2016a). Continuous water-surface level (stage or gage height) and water temperature were collected for selected inflows and all outflows. Continuous streamflows were estimated for inflows and outflows using relations between corresponding watersurface levels and streamflows measured during site visits. Additional discussion of the continuous water levels is given in the "Hydraulic and Thermal Boundary Conditions" section. 


\section{Hydraulic and Thermal Boundary Conditions}

The following subsections describe the collection of water-level (stage) measurements, streamflow measurements, temperature data, and meteorological data at each of the lakes. These data were used as hydraulic and thermal boundary conditions in the model.

\section{Madison Lake}

Lake inflow and water temperature data used in the CEQUAL-W2 model for Madison Lake were obtained from two separate channels that flow into Madison Lake. The northeast inlet streamflow (fig. 2; table 1) was measured in the channel connecting several small lakes and wetlands to Madison Lake (USGS station number 05320130). The southeast inlet streamflow (fig. 2; table 1) was measured in the channel connecting Schoolhouse and Goolsby Lake to Madison Lake (USGS station number 05320140). Submersible pressure transducers were installed at ice off and removed just before ice on for the northeast inlet and southeast inlet. While in operation (May-November 2014), transducers collected continuous measurements of water temperature and water-surface level (stage or gage height) every 15 minutes. Three corresponding measurements of streamflow and water-surface level measurements were made at each inflow site in 2014 (U.S. Geological Survey, 2016a).

Corresponding measurements of streamflow and watersurface level were used to develop rating curves that estimate continuous streamflow values based on continuously recorded water-surface levels. The continuous 15 -minute interval watersurface levels were made at Madison Lake outlet (USGS station 05320170 ), from which daily mean water-surface elevations were calculated for May 15-November 1, 2014, available online through National Water Information System (NWIS) (U.S. Geological Survey, 2016a). Rating curves were developed using graphical plotting methods similar to those described in Rantz and others (1982a, 1982b) (appendix table 1-1). Linear extrapolations were added to the upper and lower end of the rating curves to estimate streamflows outside of the range of measured streamflows. For the purposes of the model, the northeast inlet streamflow is considered the main inflow into the main water body (appendix table 1-2), flowing into segment 2 , and the southeast inlet streamflow is considered the main inflow into the secondary water body (appendix table 1-3), flowing into segment 12 (fig. 2; table 1). Additional water inflows to Madison Lake also were assumed from ungaged locations in the lake and from groundwater flow, known as distributed flow. This distributed flow was input into the model in daily time steps and distributed evenly across all of the model segments; more detail of the distributed flow is provided in the "Water Balance" section of the model calibration.

The main outflow streamflow from Madison Lake (fig. 2; table 1) is through the Madison Lake outlet, located along the southwest part of the lake out of the largest bay (USGS station number 05320170). The Madison Lake outlet streamflow is considered the sole outflow for Madison Lake (appendix table 1-4). Four corresponding measurements of streamflow and water level were made in 2014. Similar to methods used at both inflow sites, a rating curve was developed using graphical plotting methods similar to those described in Rantz and others (1982a, 1982b). Linear extrapolations were added to the upper and lower end of the rating curves to estimate streamflows outside of the range of measured streamflows, and the final rating curve was used to estimate continuous streamflow using continuously measured water levels.

The temperature data collected at 15-minute intervals at the two inlet sites were used to calculate daily mean temperature for those sites. The daily mean temperatures are available online through NWIS (U.S. Geological Survey, 2016a) for the northeast inlet (USGS station number 05320130) and for the southeast inlet (USGS station number 05320140).

Meteorological data are required as input to the CEQUAL-W2 model because of the importance of surface boundary conditions to the overall behavior of the model, specifically surface heat exchange, solar radiation absorption, wind stress, and gas exchange. Required meteorological data include air temperature, dew point temperature, wind speed, wind direction, and cloud cover. All unit conversions from the meteorological data to the required units for the model were straightforward with the exception of cloud cover. The qualitative sky cover parameter (that is, clear, scattered, broken, and overcast) was converted to an integer value ranging from 0 to 10 : clear is 1 , scattered ( $1 / 8$ to $1 / 2$ cloud coverage) is 5 , and overcast is 10 . All of the required data were available at hourly intervals for the Mankato Regional Airport (U.S. Air Force [USAF] station identification number [ID] 726585) from the Climate Data Online portal (National Climatic Data Center, 2016), located $<12.5$ kilometers ( $\mathrm{km})$ west of Madison Lake. Based on the latitude and longitude of the lake and the required meteorological inputs, evapotranspiration was included in the water balance as an internal CE-QUAL-W2 calculation.

\section{Pearl Lake}

Lake inflow and water temperature data used in the CE-QUAL-W2 model for Pearl Lake were obtained from two separate channels that flow into Pearl Lake. The southwest corner inlet streamflow was measured in the channel located at the southwest corner of Pearl Lake (fig. 3; table 1; USGS station number 05270447). The Mill Creek inlet streamflow was measured in the channel located at the northeast corner of Pearl Lake (fig. 3; table 1; USGS station number 05270448). Submersible pressure transducers were installed at ice off and removed just before ice on (May-November 2014) for the southwest corner inlet and Mill Creek inlet. While in operation, these transducers collected continuous water temperature and water-level (stage) measurements every 15 minutes. Streamflow was measured once per month from May through October at these two inflow sites (U.S. Geological Survey, 2016a). 
Methods for developing relations between streamflow and water-surface elevation for inflow and outflow sites at Pearl Lake differed from those used at Madison Lake. Graphical plotting techniques were used at Madison Lake sites because fewer streamflow measurements were collected and because the relations between streamflow and water-surface elevation were nonlinear. In contrast, linear regression analyses were used to develop relations between streamflow and water-surface elevation for inflow and outflow sites at Pearl Lake because more streamflow measurements were collected at Pearl Lake sites. In addition, relations between streamflow and water-surface elevation were linear for Pearl Lake sites. Developed linear relations were applied to water-surface elevation data collected with submersible pressure transducers at 15-minute intervals to develop continuous streamflow records for inflow and outflow sites at Pearl Lake.

Linear relations between streamflow and water-surface elevation for the southwest corner inlet and Mill Creek inlet are presented in equations 1 and 2, respectively. Equation 1 for the southwest corner inlet has a coefficient of determination $\left(R^{2}\right)$ of 0.9855 and is as follows:

$$
Q_{\text {SWCornerIllet }}=\left(2.1672 * S t E_{\text {SWCornernllet }}\right)-738.26
$$

where

$Q_{\text {SWCornerinlet }}$ is the streamflow, in cubic meters per second; and $S t E_{\text {SWCornernllet }} \quad$ is the water-surface elevation, in meters.

Daily mean streamflow was calculated based on the continuous (15-minute) streamflow records generated using equation 1, available online (USGS station number 05270447) through NWIS (U.S. Geological Survey, 2016a). Equation 2 for the Mill Creek inlet has an $R^{2}$ of 0.9715 and is as follows:

$$
Q_{\text {MillCreeknllet }}=\left(1.7206 * S t E_{\text {MillCreeknllet }}\right)-585.39
$$

where

$$
Q_{\text {MillCreekInlet }}
$$

is the streamflow, in cubic meters per second; and

StE $E_{\text {MillCreekInlet }}$ is the water-surface elevation, in meters.

Daily mean streamflows were calculated based on the continuous (15-minute) streamflow records generated using equation 2, available online (USGS station number 05270448) through NWIS (U.S. Geological Survey, 2016a). For the purposes of the model, the southwest corner inlet is considered the main inflow into the water body, flowing into segment 2, and the Mill Creek inlet is considered a tributary inflow, flowing into segment 5 (fig. 3; table 1). Additional water inflows to Pearl Lake also were assumed from ungaged locations in the lake and from groundwater flow, known as distributed flow. This distributed flow was input into the model in daily time steps and distributed evenly across all the model segments; more detail of the distributed flow is provided in the "Water Balance" section of the model calibration.
The main outflow from Pearl Lake is through the Pearl Lake outlet, located along the north part of the lake (fig. 3; table 1). Equation 3 for the Pearl Lake outlet has an $R^{2}$ of 0.9586 and is as follows:

$$
Q_{\text {PearlLakeOutlet }}=\left(4.6483 * S t E_{\text {PearlLakeOutlet }}\right)-1581.1
$$

where

$Q_{\text {PearlLakeOutlet }}$
is the streamflow, in cubic meters per
second; and
StE $E_{\text {PearlLakeOutlet }}$ is the water-surface elevation, in meters.

Daily mean streamflows were calculated based on the continuous (15-minute) streamflow records generated using equation 3 for Pearl Lake outlet, available online (USGS station number 05270449) through NWIS (U.S. Geological Survey, 2016a). Water-surface elevations for Pearl Lake were based on the transducer record collected at the Pearl Lake outlet site and are also available online (USGS station number 05270449) through NWIS (U.S. Geological Survey, 2016a).

The temperature data collected at 15 -minute intervals at the two inlet sites were used to calculate daily mean temperature for those sites. The daily mean temperatures are available online through NWIS (U.S. Geological Survey, 2016a) for the southwest corner inlet (USGS station number 05270447) and the Mill Creek inlet (USGS station number 05270448).

All of the required meteorological data were available at hourly intervals for the Saint Cloud Regional Airport (USAF station ID 726550) from the Climate Data Online portal (National Climatic Data Center, 2016), approximately $25 \mathrm{~km}$ northeast of Pearl Lake. Based on the latitude and longitude of the lake and the required meteorological inputs, evapotranspiration was included in the water balance as an internal CEQUAL-W2 calculation. The meteorological data required for the Pearl Lake CE-QUAL-W2 model were the same as those described in the previous section for Madison Lake.

\section{Water-Quality, Data Collection, Vertical Profiles, and Laboratory Analyses}

Limnological characteristics, including properties that could affect trophic state, were examined at one site for each lake (table 1): southwest deep point at Madison Lake and Pearl Lake deep point at Pearl Lake. The Madison Lake site was sampled five times and the Pearl Lake site was sampled six times from May through November 2014 by MNDNR staff. Samples were collected near the surface and at depth, respectively $(2 \mathrm{~m}$ and $16.5 \mathrm{~m}$ in Madison Lake; $2 \mathrm{~m}$ and $4.5 \mathrm{~m}$ in Pearl Lake), using a Kemmerer sampler (Wildco 1200E; Wildlife Supply Co., Yulee, Florida) and were analyzed using the methods in table 2 to determine concentrations of nutrients, chlorophyll $a$, total dissolved solids, major ions (total silica and dissolved iron), and algal counts. Water samples were filtered (through a 0.45 -micrometer filter for dissolved analysis or not filtered for total analysis) and preserved as required 
(U.S. Environmental Protection Agency, 1993a, 1993b, 1993c, 1993d). Alkalinity was determined by incremental titration at the field location (Wilde, 2006). Secchi-disk transparency (Wetzel, 2001) was measured at each vertical profile location to estimate photic depth. Vertical profiles (approximately 1-m intervals) of temperature, $\mathrm{DO}$ concentration, $\mathrm{pH}$, and specific conductance were measured by MNDNR staff with a multiparameter Hydrolab sonde at each lake site in conjunction with the water samples.

Sampling also was done by the MNDNR at the inflows for both lakes (table 1). The same constituents and methodologies as the limnological sites were followed for these inflow sites. Sampling frequency for the inflow sites varied between the two lakes. For Madison Lake, inflow sites were sampled 4-5 times in 2014. For Pearl Lake, inflow sites were sampled 6 times in 2014.

Water samples collected by the MNDNR at the lake, inflow, and outflow sites were analyzed by the Minnesota Department of Health Environmental Laboratory (DHEL) in St. Paul, Minn., with the exception of the algae data. All of the samples analyzed by the Minnesota DHEL have been previously reviewed and published and are available online at the MNDNR Lake Finder (Minnesota Department of Natural Resources, 2016e) by searching by lake number (Madison Lake is 07004400; Pearl Lake is 73003700) or by lake name and county (Minnesota Department of Natural Resources, 2016e). The algae data were produced by a phytoplankton enumeration technique performed by PhycoTech, Inc. (PhycoTech, 2017); all of the raw algal data are presented in appendix table $2-1$, presented by relative count, and then converted to algal biomass by assuming an algal biomass (in milligrams per liter) to chlorophyll $a$ (in micrograms per liter) ratio of 0.10 and multiplying by the chlorophyll $a$ concentration collected on the same day.

A primary data-quality objective was to ensure that samples were representative of the water bodies under investigation. Quality assurance was assessed with specific procedures, such as instrument calibration, to ensure data reliability and assess the quality of the sample data. The quality-assurance plan for this study followed MNDNR guidelines (Anderson and Martin, 2015). Additional quality assurance specific to Minnesota DHEL is available online (Minnesota Department of Health, 2016). Results from available quality-assurance data associated with water-quality data used for input to the model and for calibration and validation of the model were reviewed prior to the modeling efforts. Overall, the waterquality datasets (discrete samples collected at specific streamflow or lake elevations) for the calibration and validation periods were considered appropriate for the range of environmental conditions simulated for this study.

Table 2. Water-quality methods for constituents analyzed in water samples from Madison Lake and Pearl Lake, 2014.

[EPA, U.S. Environmental Protection Agency; mg/L, milligram per liter; SM, standard method; --, not analyzed]

\begin{tabular}{|c|c|c|}
\hline \multirow[b]{2}{*}{ Constituent } & \multicolumn{2}{|c|}{ Minnesota Department of Health Environmental Laboratory } \\
\hline & Method & $\begin{array}{l}\text { Method detection } \\
\text { limit }^{1}\end{array}$ \\
\hline Dissolved nitrate plus nitrite as nitrogen & EPA 353.2 (U.S. Environmental Protection Agency, 1993a) & $0.05 \mathrm{mg} / \mathrm{L}$ \\
\hline Dissolved ammonia as nitrogen & EPA 350.1 (U.S. Environmental Protection Agency, 1993b) & $0.05 \mathrm{mg} / \mathrm{L}$ \\
\hline Dissolved phosphorus as phosphorus & EPA 365.1 (U.S. Environmental Protection Agency, 1993d) & $0.01 \mathrm{mg} / \mathrm{L}$ \\
\hline Dissolved orthophosphate as phosphorus & EPA 365.1 (U.S. Environmental Protection Agency, 1993d) & $0.005 \mathrm{mg} / \mathrm{L}$ \\
\hline Chlorophyll- $a$ & SM 10200-H (American Water Works Association and others, 1997b) & $0.001 \mathrm{mg} / \mathrm{L}$ \\
\hline Total dissolved solids & SM 2540C (American Water Works Association and others, 1997c) & $10 \mathrm{mg} / \mathrm{L}$ \\
\hline Dissolved iron & EPA 200.7 (U.S. Environmental Protection Agency, 2007) & $0.001 \mathrm{mg} / \mathrm{L}$ \\
\hline
\end{tabular}

${ }^{1}$ The minimum detection limit is the minimum concentration of a substance that can be measured and reported with a 99-percent confidence that the analyte concentration is greater than zero (U.S. Environmental Protection Agency, 2002). 


\section{Initial Conditions}

Water-quality modeling was incorporated into a hydrodynamic model for each lake. Each simulated constituent (including temperature) must have an initial, single concentration for the entire lake or a gridwide initial vertical profile of concentrations at the start of each model run. Initial constituent concentrations for Madison and Pearl Lakes are presented in table 3; initial constituent concentrations were considered uniform throughout both lakes for every segment and layer, except in cases with a reported range of values in a vertical profile. Initial water-surface elevation and water temperature were set to the measured value at the simulation start for both lakes.

Table 3. Initial constituent concentrations for Madison and Pearl Lakes for the 2014 calibration runs.

[m NAVD 88; meters above North American Vertical Datum of 1988; mg/L, milligram per liter; DOM, dissolved organic matter; POM, particulate organic matter; ${ }^{\circ} \mathrm{C}$, degrees Celsius]

\begin{tabular}{|c|c|c|}
\hline Constituent & $\begin{array}{l}\text { Madison } \\
\text { Lake }\end{array}$ & $\begin{array}{l}\text { Pearl } \\
\text { Lake }\end{array}$ \\
\hline Initial water-surface elevation, m NAVD 88 & 310.57 & 340.38 \\
\hline Total dissolved solids, mg/L & 177.7 & 199.1 \\
\hline $\begin{array}{l}\text { Dissolved orthophosphate as phosphorus, } \\
\mathrm{mg} / \mathrm{L}\end{array}$ & 0.005 & 0.0025 \\
\hline Dissolved ammonia as nitrogen, $\mathrm{mg} / \mathrm{L}$ & 0.05 & 0.025 \\
\hline $\begin{array}{l}\text { Dissolved nitrate plus nitrite as nitrogen, } \\
\mathrm{mg} / \mathrm{L}\end{array}$ & 0.38 & 0.32 \\
\hline Dissolved silica, mg/L & 3.95 & 9.84 \\
\hline Particulate silica, mg/L & 1 & 1 \\
\hline Total iron, $\mathrm{mg} / \mathrm{L}$ & 0.014 & 0.014 \\
\hline Labile DOM, mg/L & 4.9510 & 1.6598 \\
\hline Refractory DOM, mg/L & 11.5522 & 3.8730 \\
\hline Labile POM, mg/L & 0.1490 & 0.5902 \\
\hline Refractory POM, mg/L & 0.3478 & 1.3770 \\
\hline Bacillariophyta/crysophyta, mg/L & 2.7 & 0.025 \\
\hline Chlorophyta (green algae), mg/L & 0.0003 & 0.025 \\
\hline Cyanophyta (blue-green algae), mg/L & 0.002 & 0.025 \\
\hline Haptophyta/cryptophyta, mg/L & 0.0007 & 0.025 \\
\hline Dissolved oxygen, $\mathrm{mg} / \mathrm{L}$ & ${ }^{1} 0.75-10.25$ & 13 \\
\hline Inorganic carbon, $\mathrm{mg} / \mathrm{L}$ & 170.4 & 207 \\
\hline Alkalinity, mg/L & 140 & 170 \\
\hline Initial temperature, ${ }^{\circ} \mathrm{C}$ & 9.9 & 9.0 \\
\hline Sediment temperature, ${ }^{\circ} \mathrm{C}$ & 14.2 & 6.1 \\
\hline
\end{tabular}

${ }^{1}$ Initial constituent concentrations were considered uniform throughout the lake for every segment and layer, except in cases with a reported range of values, which constitutes a vertical profile. The highest value is at the surface layer, with the lowest value at the bottom layer, with iterative values in between for each of the layers.

\section{Chemical Boundary Conditions}

Each simulated water-quality constituent, including total dissolved solids, nutrients, silica, iron, organic matter, and inorganic carbon, must have a daily concentration value for all inflow tributaries (including distributed tributary flow). Because of the low frequency of discrete water-quality samples, a mean daily concentration value was linearly interpolated between the discrete samples for each inflow tributary or a single concentration was applied for the entire model run for each inflow tributary. The Madison Lake distributed tributary inflow constituents were based on the mean concentrations for the northeast inlet site for branch 1 and the southeast inlet for branch 2. The Pearl Lake distributed tributary inflow constituents were based on the mean concentrations for the southwest corner inlet site.

Organic matter concentrations were back-calculated from the total Kjeldahl nitrogen concentration minus the dissolved ammonia concentration, with an additional calculation based on a linear relation between streamflow and the particulate organic nitrogen to total organic nitrogen ratio (Smith and others, 2014). Organic matter concentrations were then further divided into four separate pools, as required by the CE-QUAL-W2 model (Cole and Wells, 2015): labile dissolved, refractory dissolved, labile particulate, and refractory particulate, with dissolved and particulate pools separated into labile and refractory at 30 and 70 percent, respectively.

\section{Model Parameters}

Numerous CE-QUAL-W2 models have shown that the default hydraulic parameters are robust across different hydrologic settings (Cole and Wells, 2015). Most of the default hydraulic parameters that control the hydrodynamics and heat exchange provided within CE-QUAL-W2 V4.0 or the CE-QUAL-W2 manual (Cole and Wells, 2015). The density control for all inflows in the model allowed for the water inflows to match up with the layers within the lake that corresponded to the inflow density.

For the water-quality algorithms, 200 parameters control the constituent kinetics (table 4). An advantage of CE-QUAL-W2 is the modular design that allows for control of the water-quality constituents by adding specific subroutines. Many of these parameters were optional depending on the inclusion of groups such as epiphyton, zooplankton, macrophytes, and algae. Only the parameters required for the lake applications were included in table 4 . As with the hydraulic and heat exchange parameters that control the hydrodynamics, all of the parameters were time and space invariant. The option exists to vary some parameters, such as the extinction coefficient of water; however, not enough data were collected to justify dynamic control of any parameters. 
Table 4. Model parameters used for the water-quality algorithms for Madison Lake and Pearl Lake.

[Bold text indicates parameters adjusted from default value. $\mathrm{m}^{-1}$, per meter; $\mathrm{m}^{-1}\left(\mathrm{~g} \cdot \mathrm{m}^{-3}\right)$, per meter per grams per cubic meter; $\mathrm{g} \cdot \mathrm{m}^{-3}$, grams per cubic meter; day $^{-1}$, per day; $\mathrm{m} \cdot \mathrm{day}^{-1}$, meters per day; $\mathrm{W} /\left(\mathrm{m}^{2} \cdot{ }^{\circ} \mathrm{C}\right)$, watts per square meter per degree Celsius; $\mathrm{W} \cdot \mathrm{m}^{-2}$, watts per square meter; ${ }^{\circ} \mathrm{C}$, degrees Celsius; $\mathrm{m}^{2} \cdot \mathrm{s}^{-1} ; \mathrm{square}$ meters per second; $\mathrm{m} \cdot \mathrm{s}^{-1}$; meters per second; POM, particulate organic matter; DOM, dissolved organic matter; SOD, sediment oxygen demand; SED, sediment]

\begin{tabular}{|c|c|c|c|}
\hline \multirow{2}{*}{ Parameter } & \multirow{2}{*}{ Description } & \multicolumn{2}{|c|}{ Parameter value } \\
\hline & & Madison Lake & Pearl Lake \\
\hline $\mathrm{AX}$ & Horizontal eddy coefficient, $\mathrm{m}^{2} \cdot \mathrm{s}^{-1}$ & 1.0 & 1.0 \\
\hline CBHE & Sediment heat exchange coefficient, $\mathrm{W} /\left(\mathrm{m}^{2} \cdot{ }^{\circ} \mathrm{C}\right)$ & 1.5 & 1.3 \\
\hline FI & Interfacial friction factor & 0.015 & 0.015 \\
\hline TSEDF & Heat lost to sediments that is added back to water column & 0.75 & 0.10 \\
\hline EXH2O & Light extinction for pure water, $\mathrm{m}^{-1}$ & 0.25 & 0.25 \\
\hline EXSS & Light extinction due to inorganic suspended solids, $\mathrm{m}^{-1}$ & 0.10 & 0.20 \\
\hline EXOM & Light extinction due to organic suspended solids, $\mathrm{m}^{-1}$ & 0.10 & 0.20 \\
\hline BETA & Fraction of incident solar radiation absorbed at water surface & 0.55 & 0.45 \\
\hline EXA1 & Light extinction due to algae (bacillariophyta/crysophyta), $\mathrm{m}^{-1} /\left(\mathrm{g} \cdot \mathrm{m}^{-3}\right)$ & 0.1 & 0.2 \\
\hline EXM1 & Light extinction due to macrophytes, $\mathrm{m}^{-1} /\left(\mathrm{g} \cdot \mathrm{m}^{-3}\right)$ & 0.05 & 0.01 \\
\hline AG & Maximum algal growth rate (bacillariophyta/crysophyta), day ${ }^{-1}$ & 3.82 & 1.38 \\
\hline AG & Maximum algal growth rate (green), day ${ }^{-1}$ & 2.10 & 1.21 \\
\hline $\mathrm{AG}$ & Maximum algal growth rate (blue-green), day ${ }^{-1}$ & 1.62 & 1.38 \\
\hline AG & Maximum algal growth rate (haptophyta/cryptophyta), day ${ }^{-1}$ & 2.12 & 1.52 \\
\hline AR & Maximum algal respiration rate (bacillariophyta/crysophyta), day ${ }^{-1}$ & 0.02 & 0.04 \\
\hline AR & Maximum algal respiration rate (green), day ${ }^{-1}$ & 0.04 & 0.04 \\
\hline AR & Maximum algal respiration rate (blue-green), day ${ }^{-1}$ & 0.04 & 0.04 \\
\hline AR & Maximum algal respiration rate (haptophyta/cryptophyta), day ${ }^{-1}$ & 0.04 & 0.04 \\
\hline AM & Maximum algal mortality rate (blue-green), day ${ }^{-1}$ & 0.08 & 0.12 \\
\hline $\mathrm{AM}$ & Maximum algal mortality rate (haptophyta/cryptophyta), day ${ }^{-1}$ & 0.09 & 0.07 \\
\hline AS & Algal settling rate (bacillariophyta/crysophyta), $\mathrm{m} \cdot$ day $^{-1}$ & 0.20 & 0.15 \\
\hline AS & Algal settling rate (green), $\mathrm{m} \cdot$ day $^{-1}$ & 0.12 & 0.10 \\
\hline AS & Algal settling rate (blue-green), $\mathrm{m} \cdot \mathrm{day}^{-1}$ & 0.08 & 0.10 \\
\hline AS & Algal settling rate (haptophyta/cryptophyta), $m \cdot$ day $^{-1}$ & 0.10 & 0.10 \\
\hline AHSP & Algal half-saturation for phosphorus-limited growth (bacillariophyta/crysophyta), $\mathrm{g} \cdot \mathrm{m}^{-3}$ & 0.0065 & 0.0040 \\
\hline AHSP & Algal half-saturation for phosphorus-limited growth (green), $\mathrm{g} \cdot \mathrm{m}^{-3}$ & 0.0065 & 0.0040 \\
\hline AHSP & Algal half-saturation for phosphorus-limited growth (blue-green), $\mathrm{g} \cdot \mathrm{m}^{-3}$ & 0.0062 & 0.0045 \\
\hline AHSP & Algal half-saturation for phosphorus-limited growth (haptophyta/cryptophyta), $\mathrm{g} \cdot \mathrm{m}^{-3}$ & 0.0065 & 0.0040 \\
\hline AHSN & Algal half-saturation for nitrogen-limited growth (bacillariophyta/crysophyta), $\mathrm{g} \cdot \mathrm{m}^{-3}$ & 0.025 & 0.010 \\
\hline AHSN & Algal half-saturation for nitrogen-limited growth (green), $\mathrm{g} \cdot \mathrm{m}^{-3}$ & 0.030 & 0.014 \\
\hline AHSN & Algal half-saturation for nitrogen-limited growth (blue-green), $\mathrm{g} \cdot \mathrm{m}^{-3}$ & 0.002 & 0.002 \\
\hline AHSN & Algal half-saturation for nitrogen-limited growth (haptophyta/cryptophyta), $\mathrm{g} \cdot \mathrm{m}^{-3}$ & 0.030 & 0.010 \\
\hline
\end{tabular}


Table 4. Model parameters used for the water-quality algorithms for Madison Lake and Pearl Lake.-Continued

[Bold text indicates parameters adjusted from default value. $\mathrm{m}^{-1}$, per meter; $\mathrm{m}^{-1} /\left(\mathrm{g} \cdot \mathrm{m}^{-3}\right)$, per meter per grams per cubic meter; $\mathrm{g} \cdot \mathrm{m}^{-3}$, grams per cubic meter; day $^{-1}$, per day; $\mathrm{m} \cdot$ day $^{-1}$, meters per day; $\mathrm{W} /\left(\mathrm{m}^{2} \cdot{ }^{\circ} \mathrm{C}\right)$, watts per square meter per degree Celsius; $\mathrm{W} \cdot \mathrm{m}^{-2}$, watts per square meter; ${ }^{\circ} \mathrm{C}$, degrees $\mathrm{Celsius;} \mathrm{m}^{2} \cdot \mathrm{s}^{-1} ; \mathrm{square}$ meters per second; $\mathrm{m} \cdot \mathrm{s}^{-1}$; meters per second; POM, particulate organic matter; DOM, dissolved organic matter; SOD, sediment oxygen demand; SED, sediment]

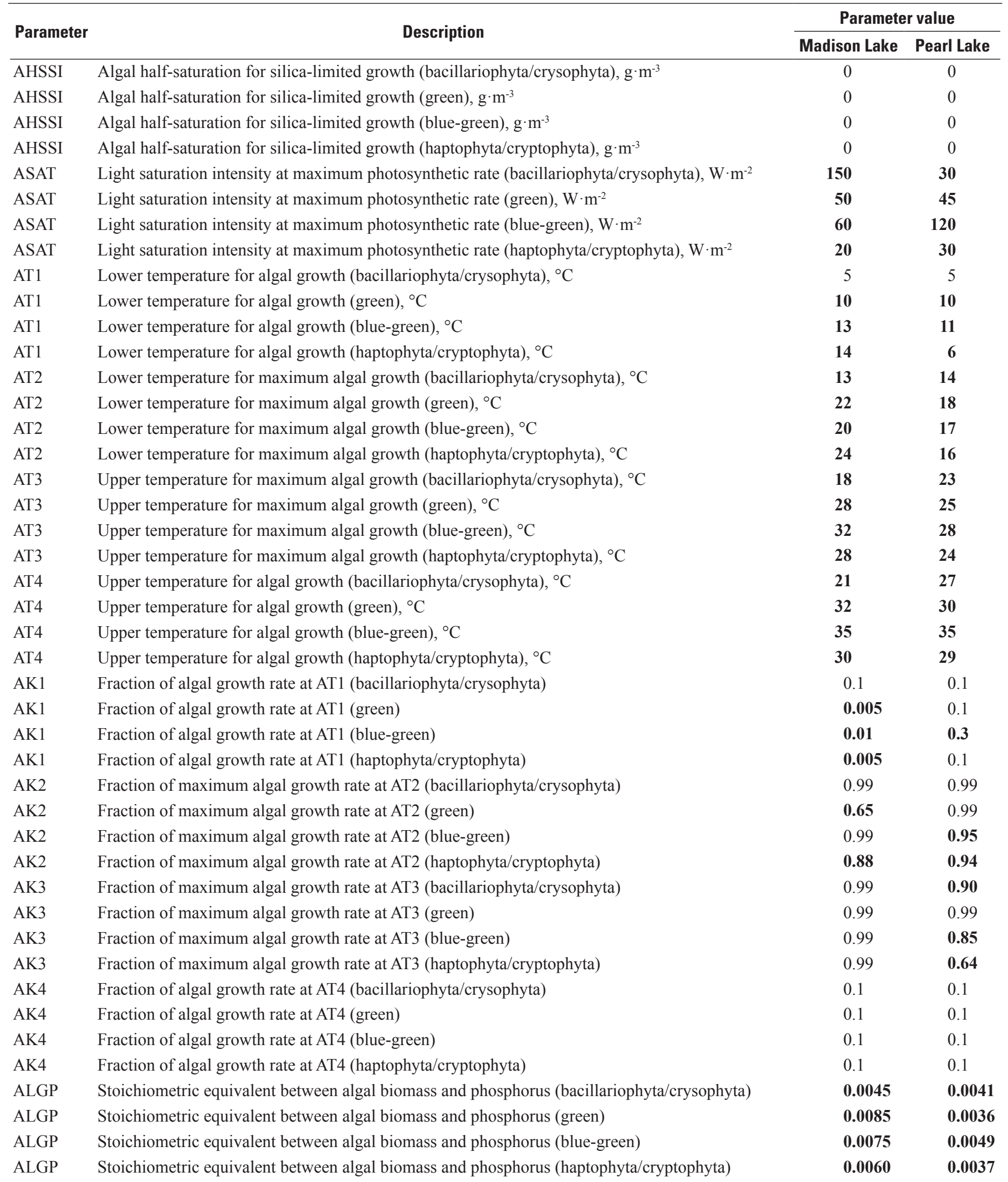


Table 4. Model parameters used for the water-quality algorithms for Madison Lake and Pearl Lake.—Continued

[Bold text indicates parameters adjusted from default value. $\mathrm{m}^{-1}$, per meter; $\mathrm{m}^{-1}\left(\mathrm{~g} \cdot \mathrm{m}^{-3}\right)$, per meter per grams per cubic meter; $\mathrm{g} \cdot \mathrm{m}^{-3}$, grams per cubic meter; day $^{-1}$, per day; $\mathrm{m} \cdot \mathrm{day}^{-1}$, meters per day; $\mathrm{W} /\left(\mathrm{m}^{2} \cdot{ }^{\circ} \mathrm{C}\right)$, watts per square meter per degree Celsius; $\mathrm{W} \cdot \mathrm{m}^{-2}$, watts per square meter; ${ }^{\circ} \mathrm{C}$, degrees Celsius; $\mathrm{m}^{2} \cdot \mathrm{s}^{-1} ; \mathrm{square}$ meters per second; $\mathrm{m} \cdot \mathrm{s}^{-1} ;$ meters per second; POM, particulate organic matter; DOM, dissolved organic matter; SOD, sediment oxygen demand; SED, sediment]

\begin{tabular}{|c|c|c|c|}
\hline \multirow{2}{*}{ Parameter } & \multirow{2}{*}{ Description } & \multicolumn{2}{|c|}{ Parameter value } \\
\hline & & Madison Lake & Pearl Lake \\
\hline ALGN & Stoichiometric equivalent between algal biomass and nitrogen (bacillariophyta/crysophyta) & $\mathbf{0 . 0 8 5}$ & 0.0795 \\
\hline ALGN & Stoichiometric equivalent between algal biomass and nitrogen (blue-green) & 0.080 & 0.0655 \\
\hline ALGN & Stoichiometric equivalent between algal biomass and nitrogen (haptophyta/cryptophyta) & 0.085 & 0.0850 \\
\hline ALGC & Stoichiometric equivalent between algal biomass and carbon (bacillariophyta/crysophyta) & 0.45 & 0.45 \\
\hline ALGC & Stoichiometric equivalent between algal biomass and carbon (blue-green) & 0.45 & 0.45 \\
\hline ALGC & Stoichiometric equivalent between algal biomass and carbon (haptophyta/cryptophyta) & 0.45 & 0.45 \\
\hline ALGSI & Stoichiometric equivalent between algal biomass and silica (bacillariophyta/crysophyta) & 0.18 & 0.18 \\
\hline ALGSI & Stoichiometric equivalent between algal biomass and silica (green) & 0.18 & 0.18 \\
\hline ALGSI & Stoichiometric equivalent between algal biomass and silica (blue-green) & 0.18 & 0.18 \\
\hline ACHLA & $\begin{array}{l}\text { Ratio between algal biomass and chlorophyll } a \text { in terms of milligrams of algae to micrograms of } \\
\text { chlorophyll } a \text { (green) }\end{array}$ & 0.10 & 0.15 \\
\hline ACHLA & $\begin{array}{l}\text { Ratio between algal biomass and chlorophyll } a \text { in terms of milligrams of algae to micrograms of } \\
\text { chlorophyll } a \text { (blue-green) }\end{array}$ & 0.06 & 0.15 \\
\hline ACHLA & $\begin{array}{l}\text { Ratio between algal biomass and chlorophyll } a \text { in terms of milligrams of algae to micrograms of } \\
\text { chlorophyll } a \text { (haptophyta/cryptophyta) }\end{array}$ & 0.10 & 0.10 \\
\hline ALPOM & $\begin{array}{l}\text { Fraction of algal biomass that is converted to particulate organic matter when algae die (bacillari- } \\
\text { ophyta/crysophyta) }\end{array}$ & 0.85 & 0.75 \\
\hline ALPOM & Fraction of algal biomass that is converted to particulate organic matter when algae die (green) & 0.70 & 0.75 \\
\hline ALPOM & Fraction of algal biomass that is converted to particulate organic matter when algae die (blue-green) & 0.70 & 0.75 \\
\hline ANPR & Algal half-saturation constant for ammonium preference (bacillariophyta/crysophyta) & 0.02 & 0.02 \\
\hline ANPR & Algal half-saturation constant for ammonium preference (green) & 0.02 & 0.02 \\
\hline ANPR & Algal half-saturation constant for ammonium preference (blue-green) & 0.02 & 0.02 \\
\hline ANPR & Algal half-saturation constant for ammonium preference (haptophyta/cryptophyta) & 0.02 & 0.02 \\
\hline O2AR & Oxygen stoichiometry for algal respiration (bacillariophyta/crysophyta) & 1.10 & 1.10 \\
\hline $\mathrm{O} 2 \mathrm{AR}$ & Oxygen stoichiometry for algal respiration (green) & 1.10 & 1.10 \\
\hline $\mathrm{O} 2 \mathrm{AR}$ & Oxygen stoichiometry for algal respiration (blue-green) & 0.95 & 1.10 \\
\hline $\mathrm{O} 2 \mathrm{AR}$ & Oxygen stoichiometry for algal respiration (haptophyta/cryptophyta) & 1.25 & 1.10 \\
\hline $\mathrm{O} 2 \mathrm{AG}$ & Oxygen stoichiometry for algal primary production (bacillariophyta/crysophyta) & 1.65 & 1.40 \\
\hline $\mathrm{O} 2 \mathrm{AG}$ & Oxygen stoichiometry for algal primary production (green) & 1.40 & 1.40 \\
\hline $\mathrm{O} 2 \mathrm{AG}$ & Oxygen stoichiometry for algal primary production (blue/green) & 1.10 & 2.40 \\
\hline $\mathrm{O} 2 \mathrm{AG}$ & Oxygen stoichiometry for algal primary production (haptophyta/cryptophyta) & 1.40 & 1.40 \\
\hline MG & Maximum macrophyte growth rate, day ${ }^{-1}$ & 0.47 & 0.57 \\
\hline MR & Maximum macrophyte respiration rate, day ${ }^{-1}$ & 0.05 & 0.05 \\
\hline MM & Maximum macrophyte mortality rate, day ${ }^{-1}$ & 0.05 & 0.05 \\
\hline
\end{tabular}


Table 4. Model parameters used for the water-quality algorithms for Madison Lake and Pearl Lake.-Continued

[Bold text indicates parameters adjusted from default value. $\mathrm{m}^{-1}$, per meter; $\mathrm{m}^{-1}\left(\mathrm{~g} \cdot \mathrm{m}^{-3}\right)$, per meter per grams per cubic meter; $\mathrm{g} \cdot \mathrm{m}^{-3}$, grams per cubic meter; day $^{-1}$, per day; $\mathrm{m} \cdot$ day $^{-1}$, meters per day; $\mathrm{W} /\left(\mathrm{m}^{2} \cdot{ }^{\circ} \mathrm{C}\right)$, watts per square meter per degree Celsius; $\mathrm{W} \cdot \mathrm{m}^{-2}$, watts per square meter; ${ }^{\circ} \mathrm{C}$, degrees $\mathrm{Celsius;} \mathrm{m}^{2} \cdot \mathrm{s}^{-1} ; \mathrm{square}$ meters per second; $\mathrm{m}^{-1} \mathrm{~s}^{-1}$; meters per second; POM, particulate organic matter; DOM, dissolved organic matter; SOD, sediment oxygen demand; SED, sediment]

\begin{tabular}{|c|c|c|c|}
\hline \multirow{2}{*}{ Parameter } & \multirow{2}{*}{ Description } & \multicolumn{2}{|c|}{ Parameter value } \\
\hline & & Madison Lake & Pearl Lake \\
\hline MSAT & Light saturation intensity at maximum photosynthetic rate, $\mathrm{W} \cdot \mathrm{m}^{-2}$ & 75 & 20 \\
\hline MHSN & Macrophyte half-saturation for nitrogen-limited growth, $\mathrm{g} \cdot \mathrm{m}^{-3}$ & 0 & 0 \\
\hline MHSC & Macrophyte half-saturation for carbon-limited growth, $\mathrm{g} \cdot \mathrm{m}^{-3}$ & 0 & 0 \\
\hline LRPMAC & Fraction of POM that originates as dead macrophytes becoming labile POM & 0.20 & 0.20 \\
\hline PSED & Fraction of phosphorus uptake by macrophytes obtained from sediments & 1 & 1 \\
\hline NSED & Fraction of nitrogen uptake by macrophytes obtained from sediments & 1 & 1 \\
\hline MBMP & Threshold macrophyte concentration for which growth is moved to the above layer, $\mathrm{g} \cdot \mathrm{m}^{-3}$ & 40 & 40 \\
\hline MMAX & Maximum macrophyte concentration, $\mathrm{g} \cdot \mathrm{m}^{-3}$ & 500 & 500 \\
\hline ANORM & Fraction of macrophyte surface area normal to direction of flow & 0.3 & 0.3 \\
\hline MT1 & Lower temperature for macrophyte, ${ }^{\circ} \mathrm{C}$ & 7 & 7 \\
\hline MT2 & Lower temperature for maximum macrophyte, ${ }^{\circ} \mathrm{C}$ & 10 & 10 \\
\hline MT3 & Lower temperature for maximum macrophyte, ${ }^{\circ} \mathrm{C}$ & 24 & 18 \\
\hline MT4 & Upper temperature for macrophyte, ${ }^{\circ} \mathrm{C}$ & 34 & 24 \\
\hline MK1 & Fraction of macrophyte growth rate at MT1 & 0.10 & 0.10 \\
\hline MK2 & Fraction of maximum macrophyte growth rate at MT2 & 0.99 & 0.99 \\
\hline MK3 & Fraction of maximum macrophyte growth rate at MT3 & 0.99 & 0.99 \\
\hline MK4 & Fraction of macrophyte growth rate at MT4 & 0.10 & 0.10 \\
\hline LRDDK & Labile-to-refractory DOM decay rate, day ${ }^{-1}$ & 0.02 & 0.01 \\
\hline LPOMDK & Labile POM decay rate, day ${ }^{-1}$ & 0.05 & 0.08 \\
\hline RPOMDK & Refractory POM decay rate, day ${ }^{-1}$ & 0.002 & 0.001 \\
\hline LRPDK & Labile-to-refractory POM decay rate, day ${ }^{-1}$ & 0.02 & 0.01 \\
\hline POMS & POM settling rate, $\mathrm{m} \cdot \mathrm{day}^{-1}$ & 0.125 & 0.125 \\
\hline ORGP & Stoichiometric equivalent between organic matter and phosphorus & 0.0065 & 0.0025 \\
\hline ORGN & Stoichiometric equivalent between organic matter and nitrogen & 0.0950 & 0.1050 \\
\hline ORGC & Stoichiometric equivalent between organic matter and carbon & 0.45 & 0.45 \\
\hline ORGSI & Stoichiometric equivalent between organic matter and silica & 0.18 & 0.18 \\
\hline OMT1 & Lower temperature for organic matter decay, ${ }^{\circ} \mathrm{C}$ & 5 & 4 \\
\hline OMT2 & Upper temperature for organic matter decay, ${ }^{\circ} \mathrm{C}$ & 25 & 25 \\
\hline OMK1 & Fraction of organic matter decay at OMT1 & 0.1 & 0.1 \\
\hline OMK2 & Fraction of organic matter decay at OMT2 & 0.99 & 0.99 \\
\hline PO4R & Sediment release rate of phosphorus, fraction of SOD & 0.012 & 0.0025 \\
\hline
\end{tabular}


Table 4. Model parameters used for the water-quality algorithms for Madison Lake and Pearl Lake.—Continued

[Bold text indicates parameters adjusted from default value. $\mathrm{m}^{-1}$, per meter; $\mathrm{m}^{-1} /\left(\mathrm{g} \cdot \mathrm{m}^{-3}\right)$, per meter per grams per cubic meter; $\mathrm{g} \cdot \mathrm{m}^{-3}$, grams per cubic meter; day $^{-1}$, per day; $\mathrm{m} \cdot$ day $^{-1}$, meters per day; $\mathrm{W} /\left(\mathrm{m}^{2} \cdot{ }^{\circ} \mathrm{C}\right)$, watts per square meter per degree Celsius; $\mathrm{W} \cdot \mathrm{m}^{-2}$, watts per square meter; ${ }^{\circ} \mathrm{C}$, degrees Celsius; $\mathrm{m}^{2} \cdot \mathrm{s}^{-1} ; \mathrm{square}$ meters per second; $\mathrm{m} \cdot \mathrm{s}^{-1}$; meters per second; POM, particulate organic matter; DOM, dissolved organic matter; SOD, sediment oxygen demand; SED, sediment]

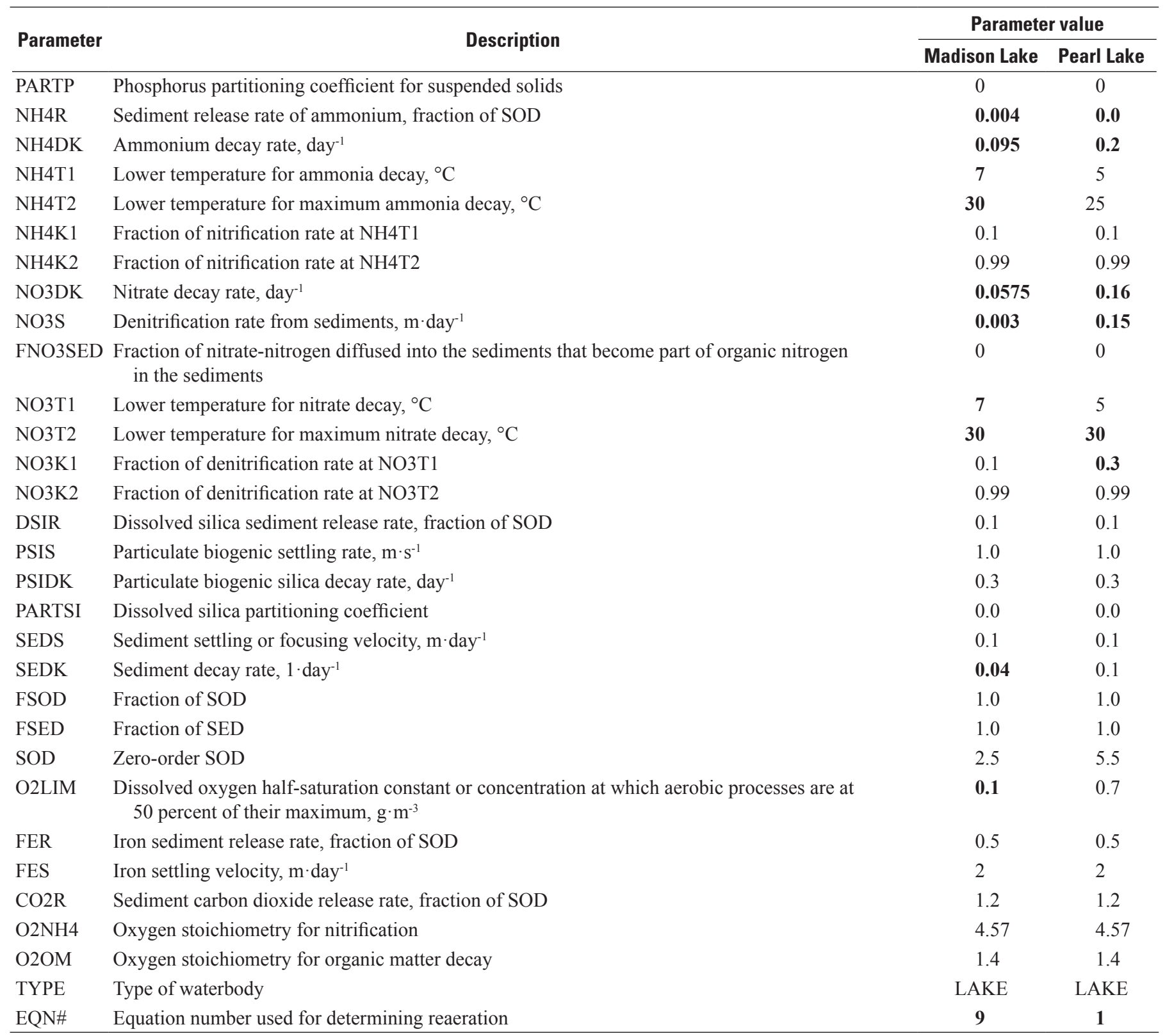


Many of the parameters in table 4 were left as the default values (88 of 200 parameters for Madison Lake; 112 of 200 parameters for Pearl Lake), whereas the remaining parameters (112 of 200 parameters for Madison Lake; 88 of 200 parameters for Pearl Lake) were adjusted during the calibration process. Guidance for adjusting selected parameters also came from other USGS CE-QUAL-W2 model applications (Bales and Robbins, 1999; Flowers and others, 2001; Green and others, 2003; Sullivan and Rounds, 2004; Galloway and Green, 2006; Galloway and others, 2008; Sullivan and others, 2011; Smith and others, 2014; Cole and Wells, 2015).

\section{Model Calibration}

The degree of fit between the simulated results and measured lake values was considered during model calibration. The two values utilized to evaluate the degree of fit were the MAE and the RMSE. The MAE, computed by equation 4 (for example, see usage in Smith and others, 2014), is a measure of the mean difference between the simulated (model) value and the measured value:

$$
\text { MAE }=\frac{1}{n} \sum_{i=1}^{n} \mid \text { simulated value-measured value } \mid
$$

where

$$
n \quad \text { is the number of observations. }
$$

For example, an MAE of 1.0 milligram per liter $(\mathrm{mg} / \mathrm{L})$ for DO means that the simulated value is on average within $1.0 \mathrm{mg} / \mathrm{L}$ of the measured DO value. The RMSE is a slightly different metric in that it indicates the amount of deviation between the simulated value and the measured value. The RMSE, as computed by equation 5 (for example, see usage in Smith and others, 2014), gives the deviation between the simulated value and the measured value approximately 67 percent of the time:

$$
\mathrm{RMSE}=\sqrt{\frac{1}{n} \sum_{i=1}^{n}(\text { simulated value }- \text { measured value })^{2}}
$$

where

$$
n \quad \text { is the number of observations. }
$$

The degree of fit between the simulated and measured outlet water-surface elevation and between the simulated and measured water temperature was only considered during the initial calibration for each of the lake models. By calibrating to water-surface elevation and water temperature first, the subsequent water-quality calibration was easier given that the effects such as wind stress, inflow water temperature, meteorological effects, and the amount of flow in and out of the lake had already been taken into account. The water-quality calibration for DO, algae, and nutrients followed, using the
MAE and RMSE metrics. In a few cases, the measured lake water-quality value was outside the simulation time period by as much as 1 day; in such cases, the water-quality measurement was compared to the closest simulated value.

Refined calibration focused on the vertical profiles of temperature and DO for both lakes (figs. 2 and 3; table 1). Additionally, the refined calibration step included the waterquality parameters highlighted previously (ammonia, nitrate plus nitrite, total Kjeldahl nitrogen, total phosphorus, orthophosphate, and chlorophyll $a$ ). Final refinement of model parameters, after several hundred iterations, was achieved with the realization of low MAE and RMSE values for most of the target constituents. Values of MAE and RMSE below 1 degree Celsius $\left({ }^{\circ} \mathrm{C}\right)$ and $<1 \mathrm{mg} / \mathrm{L}$ for DO were ideal but not possible for every location. The MAE and RMSE values for other water-quality parameters were operationally defined by other USGS reports utilizing CE-QUAL-W2, such as Smith and others (2014), which included Lake Carlos, Elk Lake, and Trout Lake. Most model runs included one adjustment with a subsequent model run to characterize the parameter sensitivity.

\section{Water Balance}

The first step in the calibration process for both lake models was the water balance. Before the water temperature and water-quality calibration could proceed, the differences between the simulated and measured water-surface elevations were rectified. A water balance was considered complete when the MAE and RMSE values were $<0.02 \mathrm{~m}$ for the simulated water-surface elevation.

\section{Madison Lake}

The initial attempt to achieve a water balance for Madison Lake used the two gaged tributaries, the northeast inlet and southeast inlet (table 1), as the sole inflows for the calibration period of May 15-November 1, 2014; however, the simulated water-surface elevation was below the measured water-surface elevation, which indicated that additional water sources to the lake existed, such as ungaged tributaries and groundwater. To include the unaccounted inflow, two different distributed tributary flows were added iteratively for each of the two water bodies of Madison Lake. These distributed tributary flows were added to all segments equally until the simulated lake water-surface elevation matched the measured lake water-surface elevation. These distributed tributary flows can be positive or negative; large positive values were determined to correlate with large precipitation events, whereas negative values usually were during the driest portions of the calibration period. Based on daily means, $<1$ percent of the total water flow was accounted for by the distributed tributary flows. A comparison between the simulated and measured water-surface elevations for Madison Lake is shown in figure 6, with MAE and RMSE values of $<0.02 \mathrm{~m}$. 


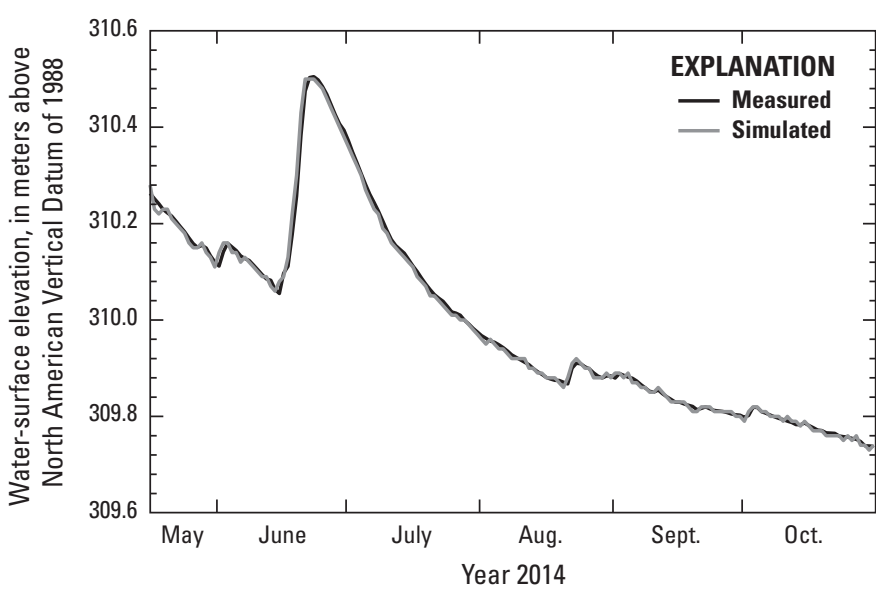

Figure 6. Simulated and measured water-surface elevations for Madison Lake, May 15 to November 1, 2014.

\section{Pearl Lake}

The initial attempt to achieve a water balance for Pearl Lake used the two gaged tributaries, the southwest corner inlet and the Mill Creek inlet (table 1), as the sole inflows for the calibration period of May 14-November 13, 2014; however, the simulated water-surface elevation was below the measured water-surface elevation, which indicated additional water sources to the lake. A distributed tributary flow for Pearl Lake was added to all segments equally and as with Madison Lake, these distributed tributary flows can be positive or negative. Based on daily means, approximately 2 percent of the total water flow was accounted for by the distributed tributary flows. A comparison between the simulated and measured water-surface elevations for Pearl Lake is shown in figure 7, with MAE and RMSE values of $<0.02 \mathrm{~m}$.

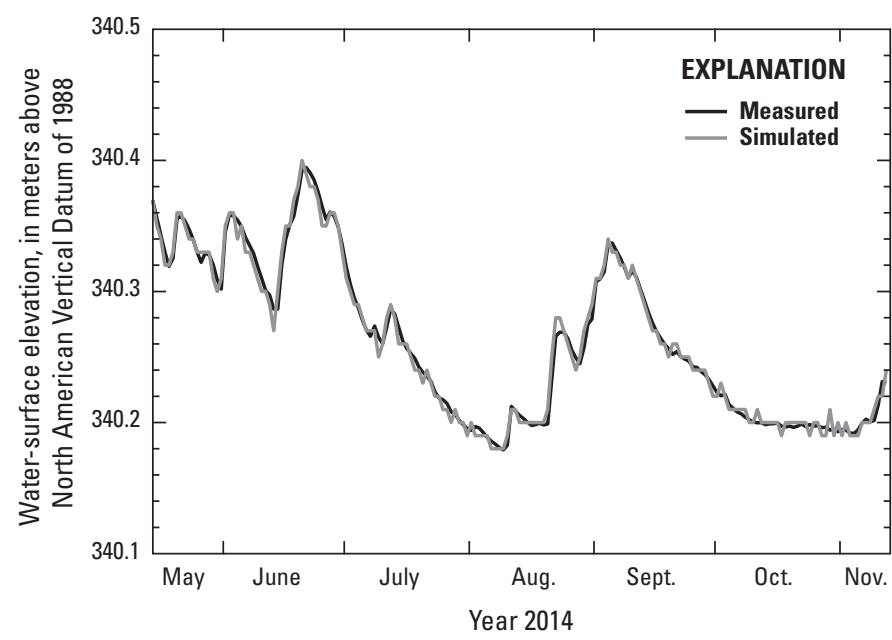

Figure 7. Simulated and measured water-surface elevations for Pearl Lake, May 14 to November 13, 2014.

\section{Temperature}

A critical calibration step is the water temperature calibration because of the effect of temperature on water density. Water temperature is a key metric to determine the accuracy of the model's calibration. Boundary conditions that affect water temperature include sediment temperature, initial lake water temperature, and inflow water temperature. Meteorological effects include air temperature, wind velocity, wind direction, and solar radiation. Because solar radiation was not directly available for any of the lake models, an internal calculation within the model was made based on the amount of cloud cover and the latitude/longitude. Wind effects can be further augmented by the wind sheltering coefficient (WSC), controlled through a separate input file, which takes into account the effects of boundary factors, such as topography and shoreline tree cover, on wind mixing. Several hydraulic parameters also affect water temperature. For example, the amount of reradiated heat back to the water column from solar radiation that penetrates the entire water column is controlled by the TSEDF parameter (table 4), a hydraulic coefficient. Another set of critical parameters includes the extinction coefficients (EXH2O, EXSS, EXOM, EXA1, EXA2, EXA3, EXA4, EXM1), which specify the water absorption of light and other ancillary extinction coefficients for organic suspended solids, inorganic suspended solids, algae, and macrophytes (table 4).

\section{Madison Lake}

In Madison Lake, the principal temperature calibration targets were data from several continuous profiles collected by thermistors at three depths in the epilimnion (1-, 3-, and 4-m depths), three depths in the transitional zone between the epilimnion and the hypolimnion (5.5-, 7-, and 9-m depths), and three depths in the hypolimnion (11-, 13-, and 16.5-m depths) at the southwest deep point site (figs. $8-10$; table 5). Eight of the nine depths had MAE and RMSE values $<0.90$ and $<1.10^{\circ} \mathrm{C}$, respectively. For most of the continuous profile depths, the simulated temperatures were approximately 1.0 to $1.5^{\circ} \mathrm{C}$ warmer than the measured temperatures until late July. After late July, the simulated and measured temperatures tracked closely to each other with the exception of the 11-m depth; the 11-m depth took longer to equilibrate to the measured temperature. Overall, the deeper locations (transitional zone and the hypolimnion) shown in figures 9 and 10 (with the exception of 11-m depth, fig. 10), had simulated profiles that approximated the measured temperatures with better accuracy than the shallower locations (fig. 8). The MAE values ranged from 0.36 to $0.73{ }^{\circ} \mathrm{C}$ and the RMSE values ranged from 0.51 to $0.94{ }^{\circ} \mathrm{C}$ for the depths at or below $5.5 \mathrm{~m}$, not including the $11-\mathrm{m}$ depth. For the epilimnion depths shown in figure 8 , the CE-QUAL-W2 model's inherent thermal stability does not as easily account for short-term shifts in shallow mixing in comparison to long-term shifts, which could have accounted for temperature offsets between simulated and measured values. The WSC was adjusted from 0.50 to 0.95 to try to compensate 
for the shallow temperature offsets; however, these adjustments were used sparingly given the lack of measured data to support frequent adjustments in the WSC. Of the three different depth classes, the transitional zones shown in figure 9 had the lowest MAE and RMSE values; the transitional zone between the epilimnion and hypolimnion generally can have larger deviations between simulated and measured values, so these low statistical measures demonstrated the strong temperature calibration for Madison Lake.

Secondary calibration targets for Madison Lake were several continuous thermistors at one depth in the epilimnion (1-m depths) and two depths in the transitional zone between

Table 5. Summary of values of mean absolute error (MAE) and root mean square error (RMSE) for calibration runs for Madison Lake and Pearl Lake.

$\left[{ }^{\circ} \mathrm{C}\right.$, degrees Celsius; Minn. Minnesota; multiple, integrated vertical profile data; mg/L, milligram per liter; $\mu \mathrm{g} / \mathrm{L}$, microgram per liter; <, less than]

\begin{tabular}{|c|c|c|c|c|c|c|}
\hline Constituent & Site name & $\begin{array}{l}\text { Common name in } \\
\text { report }\end{array}$ & $\begin{array}{c}\text { Depth } \\
\text { (meters) }\end{array}$ & $\begin{array}{l}\text { Number of } \\
\text { compared } \\
\text { data points }\end{array}$ & MAE & RMSE \\
\hline Water temperature, ${ }^{\circ} \mathrm{C}$ & $\begin{array}{l}\text { Madison Lake southwest deep point near } \\
\text { Madison Lake, Minn. }\end{array}$ & Southwest deep point & 1 & 170 & 0.82 & 1.07 \\
\hline Water temperature, ${ }^{\circ} \mathrm{C}$ & $\begin{array}{l}\text { Madison Lake southwest deep point near } \\
\text { Madison Lake, Minn. }\end{array}$ & Southwest deep point & 3 & 170 & 0.78 & 1.02 \\
\hline Water temperature, ${ }^{\circ} \mathrm{C}$ & $\begin{array}{l}\text { Madison Lake southwest deep point near } \\
\text { Madison Lake, Minn. }\end{array}$ & Southwest deep point & 5.5 & 170 & 0.73 & 0.94 \\
\hline Water temperature, ${ }^{\circ} \mathrm{C}$ & $\begin{array}{l}\text { Madison Lake southwest deep point near } \\
\text { Madison Lake, Minn. }\end{array}$ & Southwest deep point & 7 & 170 & 0.57 & 0.72 \\
\hline Water temperature, ${ }^{\circ} \mathrm{C}$ & $\begin{array}{l}\text { Madison Lake southwest deep point near } \\
\text { Madison Lake, Minn. }\end{array}$ & Southwest deep point & 13 & 170 & 0.65 & 0.83 \\
\hline Water temperature, ${ }^{\circ} \mathrm{C}$ & $\begin{array}{l}\text { Madison Lake southwest deep point near } \\
\text { Madison Lake, Minn. }\end{array}$ & Southwest deep point & 16.5 & 170 & 0.36 & 0.51 \\
\hline Water temperature, ${ }^{\circ} \mathrm{C}$ & $\begin{array}{l}\text { Madison Lake southwest deep point near } \\
\text { Madison Lake, Minn. }\end{array}$ & Southwest deep point & Multiple & 103 & 0.53 & 0.68 \\
\hline Water temperature, ${ }^{\circ} \mathrm{C}$ & $\begin{array}{l}\text { Madison Lake northeast deep point near } \\
\text { Madison Lake, Minn. }\end{array}$ & Northeast deep point & 1 & 70 & 1.23 & 1.40 \\
\hline Water temperature, ${ }^{\circ} \mathrm{C}$ & $\begin{array}{l}\text { Madison Lake northeast deep point near } \\
\text { Madison Lake, Minn. }\end{array}$ & Northeast deep point & 5 & 70 & 0.94 & 1.14 \\
\hline Dissolved orthophosphate as phosphorus, $\mathrm{mg} / \mathrm{L}$ & $\begin{array}{l}\text { Madison Lake southwest deep point near } \\
\text { Madison Lake, Minn. }\end{array}$ & Southwest deep point & 2 & 5 & 0.01 & 0.02 \\
\hline Dissolved ammonia as nitrogen, $\mathrm{mg} / \mathrm{L}$ & $\begin{array}{l}\text { Madison Lake southwest deep point near } \\
\text { Madison Lake, Minn. }\end{array}$ & Southwest deep point & 2 & 5 & 0.18 & 0.31 \\
\hline Dissolved nitrate plus nitrite as nitrogen, $\mathrm{mg} / \mathrm{L}$ & $\begin{array}{l}\text { Madison Lake southwest deep point near } \\
\text { Madison Lake, Minn. }\end{array}$ & Southwest deep point & 2 & 5 & 0.05 & 0.08 \\
\hline
\end{tabular}


the epilimnion and the hypolimnion (5- and 9-m depths) at the northeast deep point site (fig. 11; table 5). Similar to the southwest deep point site, the shallower simulated depth in the epilimnion deviated from the measured values more than the deeper profiles. The MAE values for all three depths ranged from 0.94 to $1.28^{\circ} \mathrm{C}$; RMSE values for all three depths ranged from 1.14 to $1.48^{\circ} \mathrm{C}$. Part of the reason for the larger MAE and RMSE values was that the temperature records at the northeast deep point site were only available until late July. The same period for the southwest deep point site showed more deviation between simulated and measured temperature than the latter portion of the year.

Table 5. Summary of values of mean absolute error (MAE) and root mean square error (RMSE) for calibration runs for Madison Lake and Pearl Lake.-Continued

${ }^{\circ} \mathrm{C}$, degrees Celsius; Minn. Minnesota; multiple, integrated vertical profile data; $\mathrm{mg} / \mathrm{L}$, milligram per liter; $\mu \mathrm{g} / \mathrm{L}$, microgram per liter; $<$, less than]

\begin{tabular}{|c|c|c|c|c|c|c|}
\hline Constituent & Site name & $\begin{array}{c}\text { Common name in } \\
\text { report }\end{array}$ & $\begin{array}{c}\text { Depth } \\
\text { (meters) }\end{array}$ & $\begin{array}{c}\text { Number of } \\
\text { compared } \\
\text { data points }\end{array}$ & MAE & RMSE \\
\hline Total phosphorus as phosphorus, $\mu \mathrm{g} / \mathrm{L}$ & $\begin{array}{l}\text { Madison Lake southwest deep point near } \\
\text { Madison Lake, Minn. }\end{array}$ & Southwest deep point & 2 & 5 & 82 & 86 \\
\hline Total phosphorus as phosphorus, $\mu \mathrm{g} / \mathrm{L}$ & $\begin{array}{l}\text { Madison Lake northeast deep point near } \\
\text { Madison Lake, Minn. }\end{array}$ & Northeast deep point & 2 & 5 & 79 & 80 \\
\hline Bacillariophyta/crysophyta, mg/L & $\begin{array}{l}\text { Madison Lake southwest deep point near } \\
\text { Madison Lake, Minn. }\end{array}$ & Southwest deep point & 2 & 5 & 0.74 & 1.00 \\
\hline Chlorophyta, mg/L & $\begin{array}{l}\text { Madison Lake southwest deep point near } \\
\text { Madison Lake, Minn. }\end{array}$ & Southwest deep point & 2 & 5 & 0.18 & 0.20 \\
\hline \multicolumn{7}{|c|}{ Pearl Lake } \\
\hline Water temperature, ${ }^{\circ} \mathrm{C}$ & Pearl Lake deep point near Marty, Minn. & Pearl Lake deep point & 1.6 & 184 & 0.60 & 0.78 \\
\hline Water temperature, ${ }^{\circ} \mathrm{C}$ & Pearl Lake deep point near Marty, Minn. & Pearl Lake deep point & 2.1 & 184 & 0.63 & 0.80 \\
\hline Water temperature, ${ }^{\circ} \mathrm{C}$ & Pearl Lake deep point near Marty, Minn. & Pearl Lake deep point & 2.8 & 184 & 0.58 & 0.78 \\
\hline Water temperature, ${ }^{\circ} \mathrm{C}$ & Pearl Lake deep point near Marty, Minn. & Pearl Lake deep point & 3.8 & 184 & 0.57 & 0.72 \\
\hline Water temperature, ${ }^{\circ} \mathrm{C}$ & Pearl Lake deep point near Marty, Minn. & Pearl Lake deep point & 4.8 & 184 & 0.70 & 0.97 \\
\hline Water temperature, ${ }^{\circ} \mathrm{C}$ & Pearl Lake deep point near Marty, Minn. & Pearl Lake deep point & 5.4 & 184 & 0.87 & 1.22 \\
\hline Water temperature, ${ }^{\circ} \mathrm{C}$ & Pearl Lake deep point near Marty, Minn. & Pearl Lake deep point & Multiple & 30 & 0.71 & 0.95 \\
\hline Total phosphorus as phosphorus, $\mu \mathrm{g} / \mathrm{L}$ & Pearl Lake deep point near Marty, Minn. & Pearl Lake deep point & 2 & 6 & 6 & 7 \\
\hline Total phosphorus as phosphorus, $\mu \mathrm{g} / \mathrm{L}$ & Pearl Lake deep point near Marty, Minn. & Pearl Lake deep point & 4.5 & 6 & 13 & 17 \\
\hline Bacillariophyta/crysophyta, mg/L & Pearl Lake deep point near Marty, Minn. & Pearl Lake deep point & 2 & 6 & 0.08 & 0.10 \\
\hline Chlorophyta, mg/L & Pearl Lake deep point near Marty, Minn. & Pearl Lake deep point & 2 & 6 & 0.05 & 0.06 \\
\hline Cyanophyta, mg/L & Pearl Lake deep point near Marty, Minn. & Pearl Lake deep point & 2 & 6 & 0.22 & 0.28 \\
\hline Haptophyta/cryptophyta, mg/L & Pearl Lake deep point near Marty, Minn. & Pearl Lake deep point & 2 & 6 & 0.13 & 0.14 \\
\hline
\end{tabular}


Simulated water temperatures in Madison Lake were compared to vertical profiles of lake water temperatures at the southwest deep point site, generally collected during MNDNR water-quality sampling trips. A total of eight dates are shown in figure 12. Similar to the continuous temperature profiles, low MAE and RMSE values provided additional confidence in the model's ability to predict water temperature. For Madison Lake, the model consistently attained MAE and RMSE values $<1.0^{\circ} \mathrm{C}$ for all eight dates, with several values $<0.5^{\circ} \mathrm{C}$. For the combined vertical profiles, the MAE and RMSE values were 0.53 and $0.68{ }^{\circ} \mathrm{C}$, respectively (table 5). In addition, the location and slope of the simulated thermocline matched the measured thermocline. Similar to the continuous temperature profiles for depths of 1 to $16.5 \mathrm{~m}$ (table 5), the simulated temperatures for Madison Lake were warmer than the measured temperatures for the earlier vertical profiles through the July 9 vertical profile (fig. 12).
Figure 9. Simulated and measured water temperature for the three different depths $(5.5,7$, and 9 meters $)$ in the transitional zone between the epilimnion and the hypolimnion at Madison Lake southwest deep point near Madison Lake, Minnesota, May 15 to November 1, 2014, with values of mean absolute error (MAE) and root mean square error (RMSE).

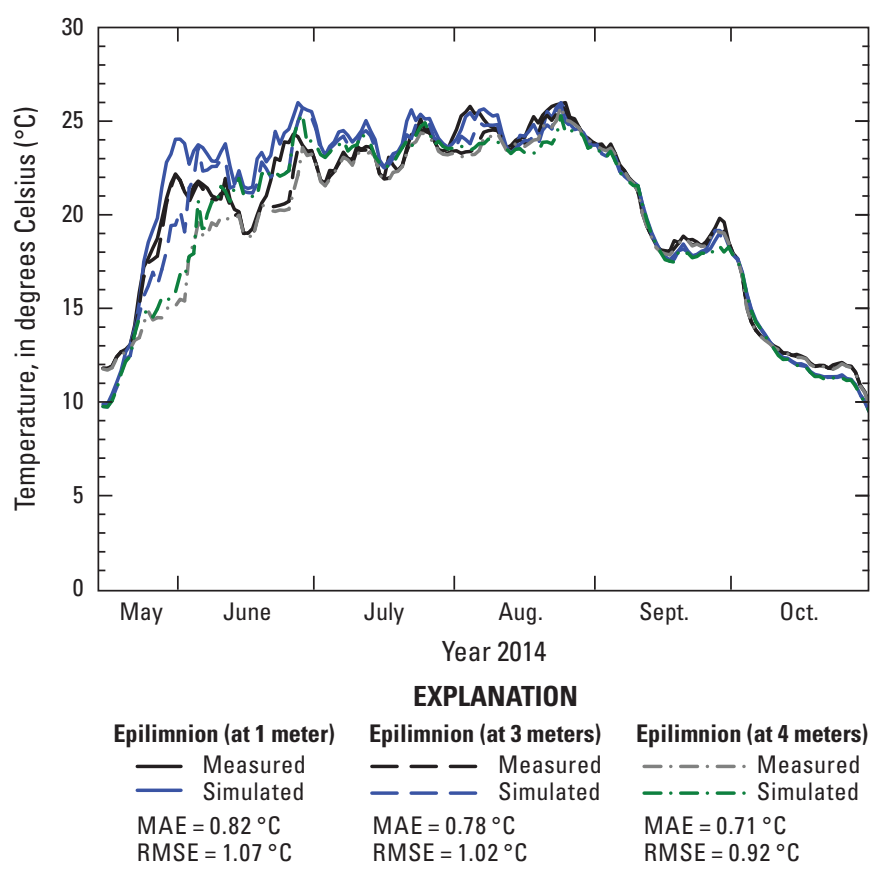

Figure 8. Simulated and measured water temperature for the three different depths (1, 3, and 4 meters) in the epilimnion at Madison Lake southwest deep point near Madison Lake, Minnesota, May 15 to November 1, 2014, with values of mean absolute error (MAE) and root mean square error (RMSE). 


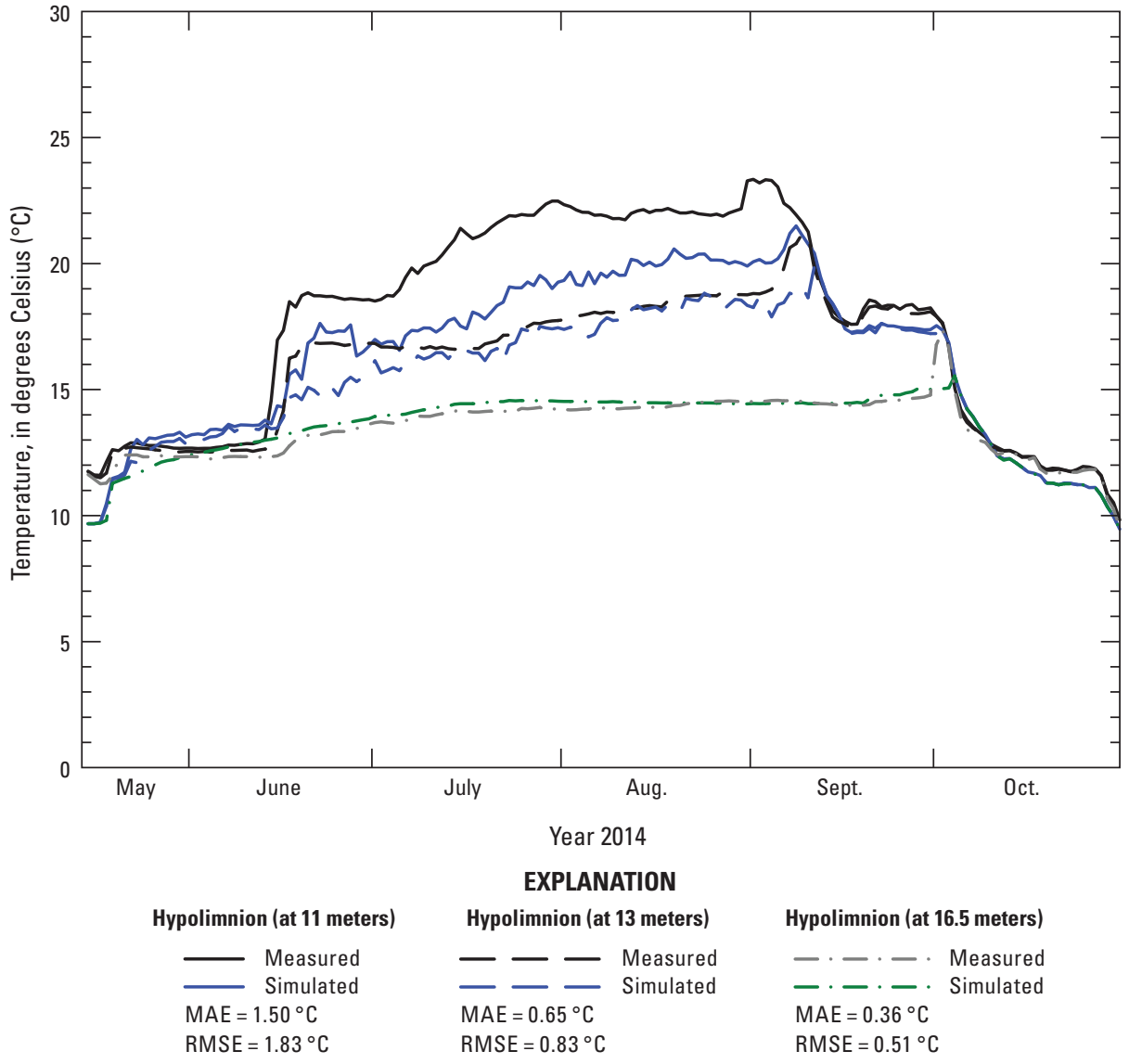

Figure 10. Simulated and measured water temperature for the three different depths (11, 13, and 16.5 meters) in the hypolimnion at Madison Lake southwest deep point near Madison Lake, Minnesota, May 15 to November 1 , 2014 , with values of mean absolute error (MAE) and root mean square error (RMSE).

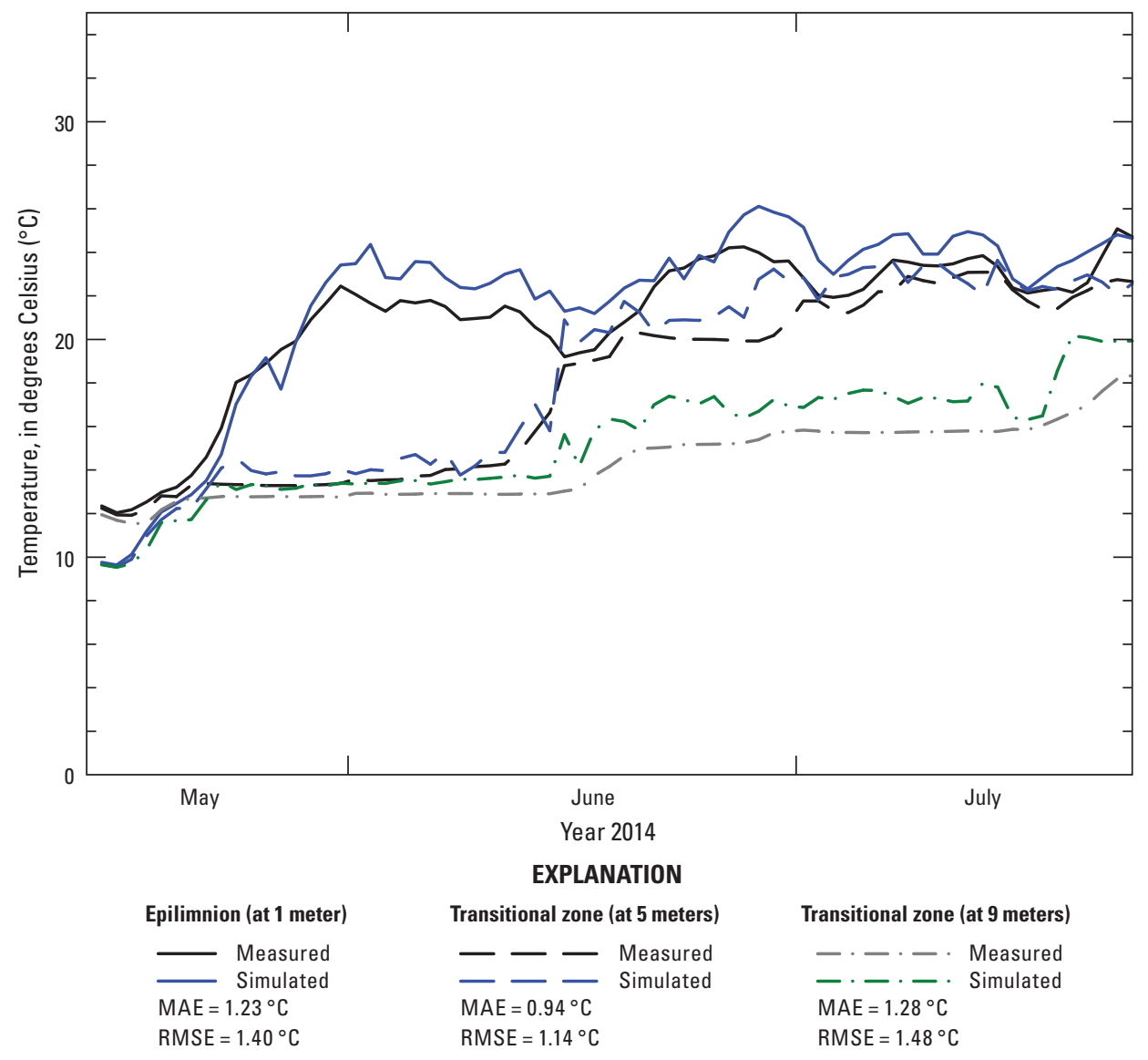

Figure 11. Simulated and measured water temperature for three different depths $(1,5$, and 9 meters) for the Madison Lake northeast deep point near Madison Lake, Minnesota, May 15 to July 23, 2014, with values of mean absolute error (MAE) and root mean square error (RMSE). 


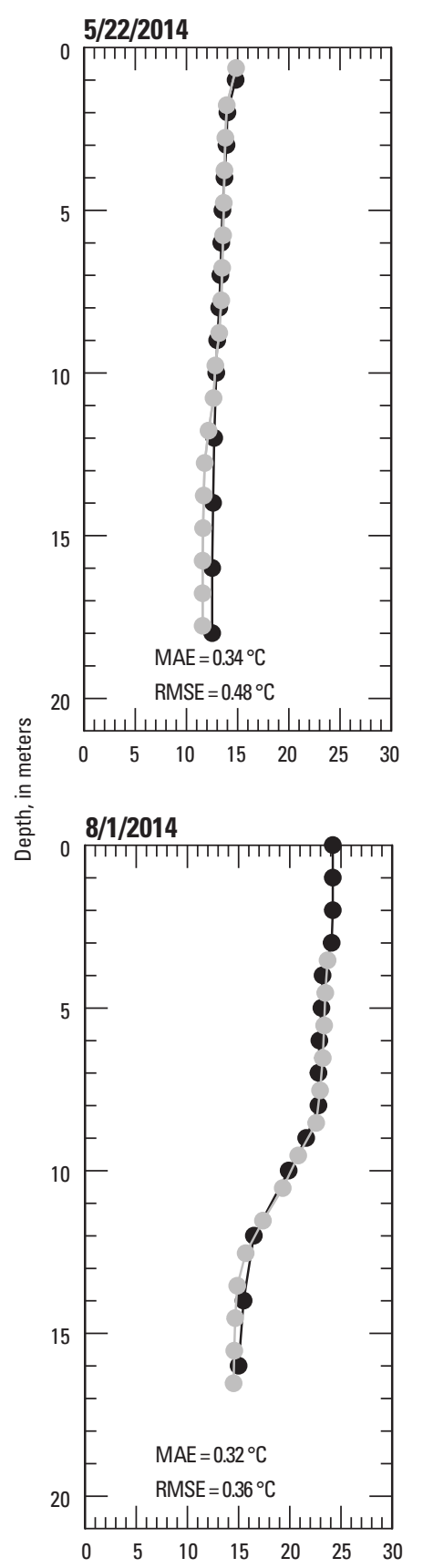

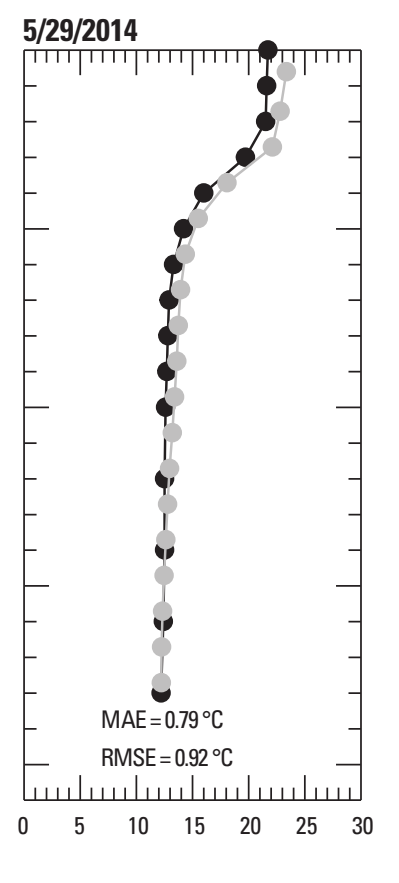

\section{6/3/2014}

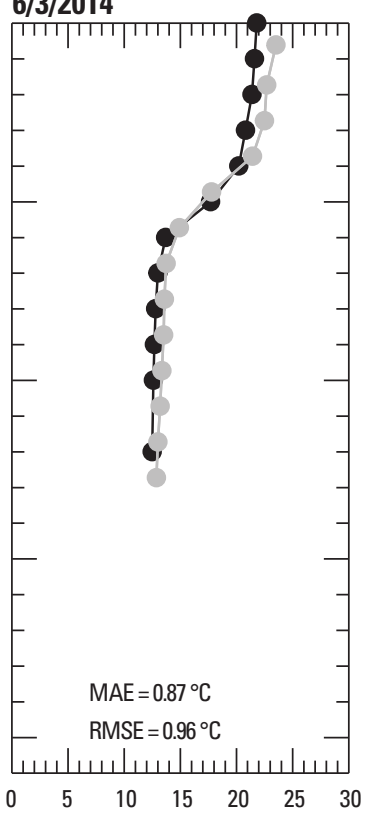

$8 / 26 / 2014$

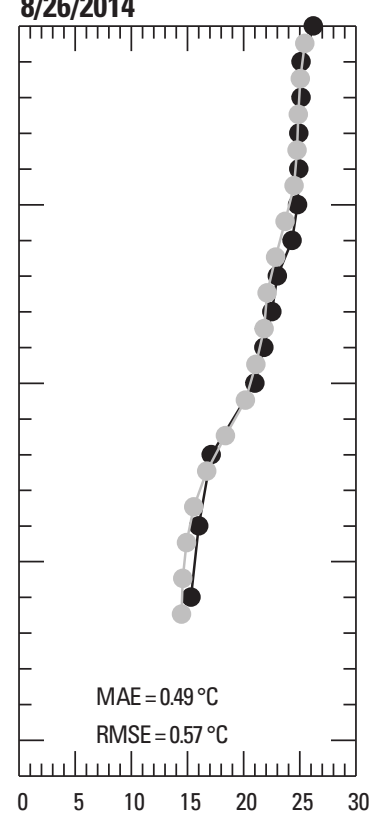

9/17/2014
7/9/2014
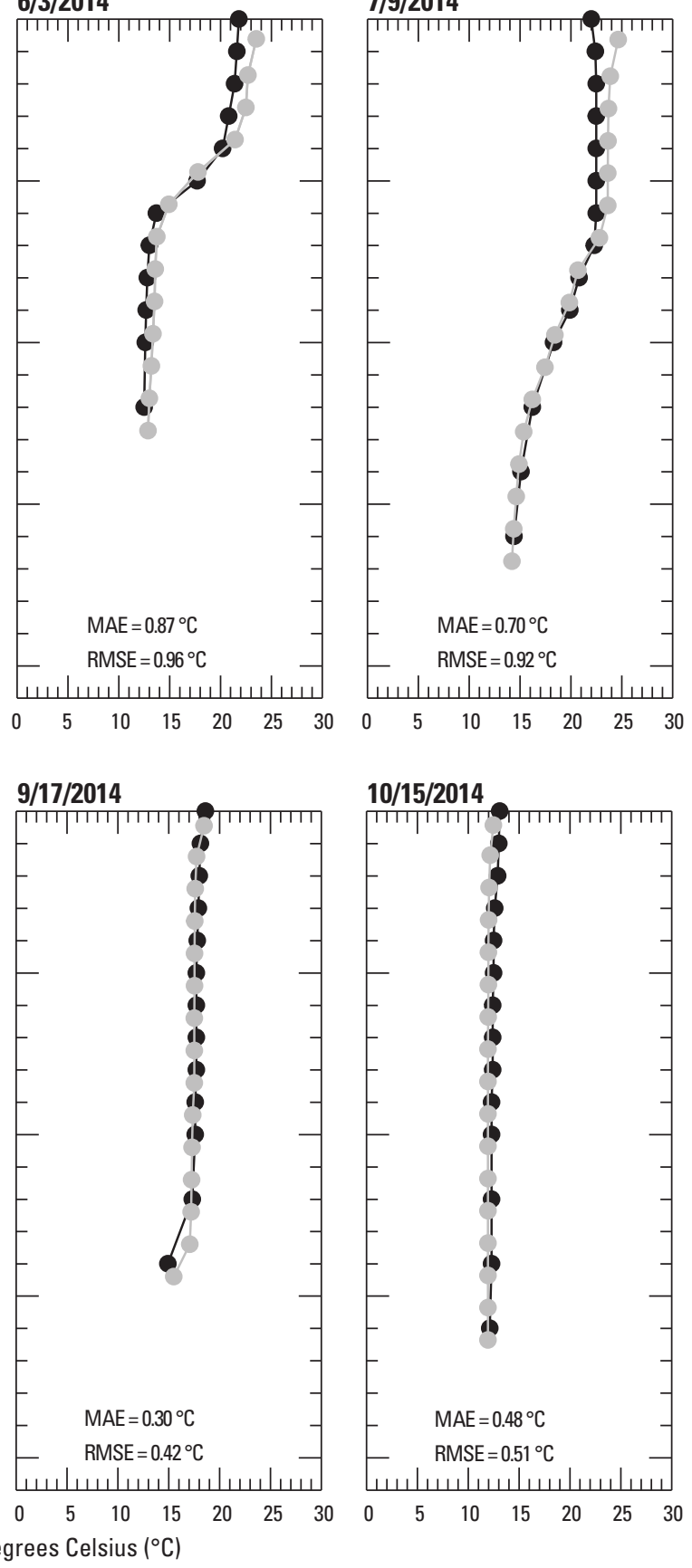

$10 / 15 / 2014$

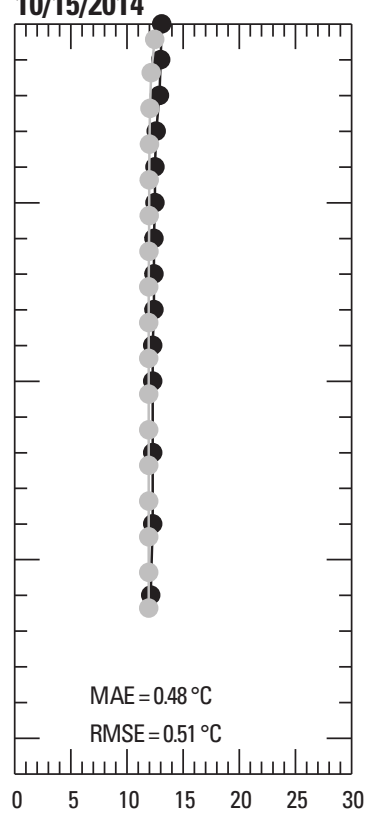

EXPLANATION

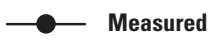

Simulated

Figure 12. Simulated and measured water temperature for vertical profiles at Madison Lake southwest deep point near Madison Lake, Minnesota, for eight dates in 2014, with values of mean absolute error (MAE) and root mean square error (RMSE). 


\section{Pearl Lake}

In Pearl Lake, the principal temperature calibration targets were data from several continuous profiles collected by thermistors at three depths in the shallow mixed layer (1.6-, 2.1-, and 2.8-m depths) and three depths in the deep mixed layer (3.8-, 4.8-, and 5.4-m depths) at the Pearl Lake deep point site (figs. 13 and 14, respectively; table 5). Five of the six depths had MAE and RMSE values $<0.80$ and $<1.00{ }^{\circ} \mathrm{C}$, respectively. For all six depths, the MAE values ranged from 0.57 to $0.87^{\circ} \mathrm{C}$, and the RMSE values ranged from 0.72 to $1.22{ }^{\circ} \mathrm{C}$. Throughout the year, temperatures were well-mixed in Pearl Lake, and the simulated temperatures tracked closely to the measured temperatures. Given the shallow depth of Pearl Lake compared to Madison Lake, wind mixing seemed to be able to account for the minor differences near the lake bottom (figs. 13 and 14). The largest difference between the simulated and measured temperatures occurred for the deepest mixed layer location (5.4 m) in early August (fig. 14). The WSC was adjusted from 0.80 to 1.00 to try to account for the small temperature offsets at depth; however, compared to the larger adjustment range for Madison Lake, these adjustments were small and lend theoretical support to the ease of shallow lake mixing.
Simulated water temperatures in Pearl Lake also were compared to vertical profiles of lake water temperatures at the Pearl Lake deep point collected by the MNDNR. A total of six dates are shown in figure 15. Similar to the Madison Lake continuous temperature profiles, low MAE and RMSE values provided additional confidence in the model's ability to predict water temperature. The calibration fit between measured and simulated temperatures earlier in 2014 was not as close as the fit for Madison Lake, particularly in the deeper portion of the mixed layer near the lake bottom. Similar to the deepest continuous profile at $5.4 \mathrm{~m}$ (fig. 14), the shallow depths of Pearl Lake caused wind energy to mix warmer surface water too efficiently to the bottom of the lake. Therefore, the warmer temperatures near the bottom of the lake could have been dissipated by a lower WSC; however, the cooler temperatures would have further offset the DO concentrations at depth as described in the "Dissolved Oxygen" section. For Pearl Lake, the last four temperature vertical profiles (after June 24) had consistently low MAE and RMSE values $<1.0{ }^{\circ} \mathrm{C}$, whereas the first two dates (May 27 and June 24) were greater than or equal to $1.0^{\circ} \mathrm{C}$ (fig. 15). For the combined vertical profiles, the MAE and RMSE values were 0.71 and $0.95^{\circ} \mathrm{C}$, respectively (table 5).

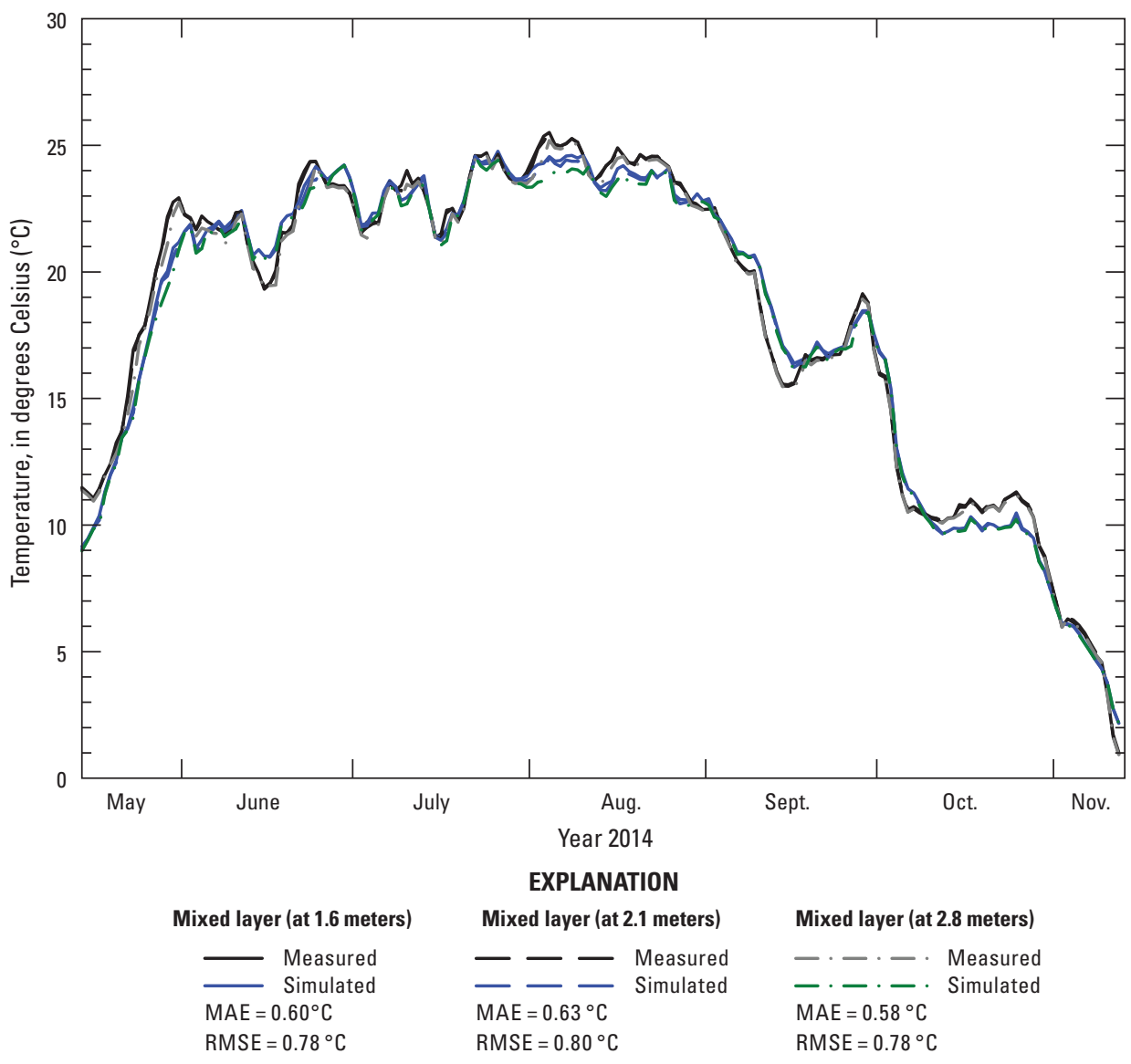

Figure 13. Simulated and measured water temperature for the three different depths $(1.6,2.1$, and 2.8 meters) in the shallow mixed layer at the Pearl Lake Deep Point near Marty, Minnesota, May 14 to November 13, 2014, with values of mean absolute error (MAE) and root mean square error (RMSE). 


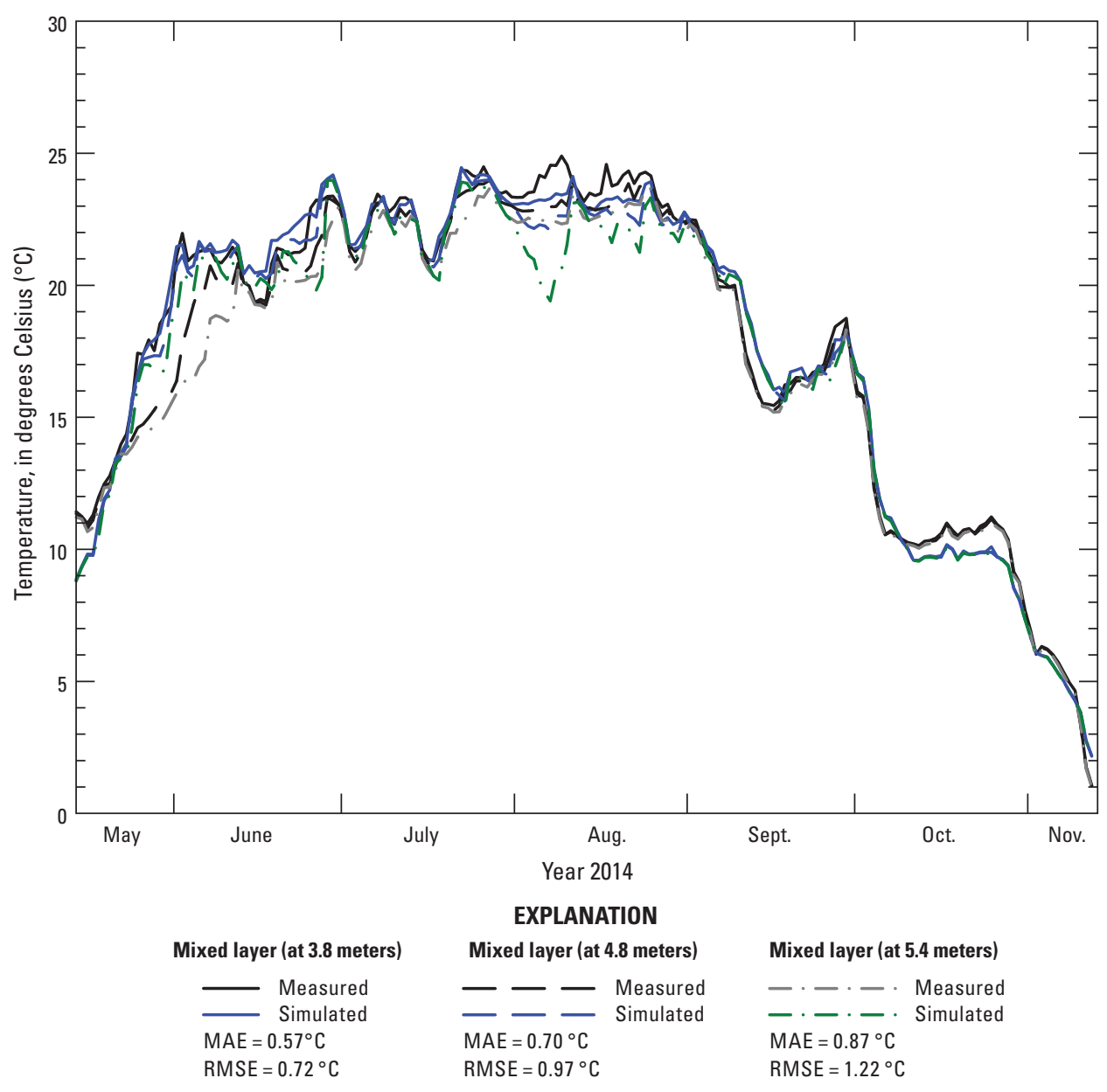

Figure 14. Simulated and measured water temperature for the three different depths $(3.8,4.8$, and 5.4 meters) in the deep mixed layer at the Pearl Lake Deep Point near Marty, Minnesota, May 14, to November 13, 2014, with values of mean absolute error (MAE) and root mean square error (RMSE).

\section{Dissolved Oxygen}

Fish species and other aquatic organisms cannot survive without adequate DO. Accurately simulating DO is critical in determining the size of summer habitat refugia for important game fish species because their thermal requirements often confine them below the epilimnion where they are vulnerable to mass die offs because of a lack of DO. For example, Jacobson and others (2008) evaluated the lethal oxythermal niche boundary for ciscoes in several Minnesota lakes and determined that lethal temperatures decreased for lower lethal DO concentrations. Even cool-water and warm-water fish species have upper thermal tolerances. If these fish subsist for long periods in warmer waters in combination with low DO levels, even noncold-water fish can be subject to die offs (Fang and others, 1999) based on oxythermal constraints.

Within the CE-QUAL-W2 model, many sources and sinks are available for DO, which makes DO likely the most complicated constituent to model. Along with temperature, DO is a key metric to illustrate the accuracy of the model's calibration. Sources include inflows, atmospheric exchange across the lake surface, and algal photosynthesis (Cole and Wells, 2015). Sinks include decay mechanisms such as bacterial respiration of dissolved and solid-phase organic matter (labile and refractory) in the water column and lake sediment. Other simulated sinks include algal respiration, macrophyte respiration, ammonia and nitrite nitrification, and exchange back to the atmosphere and into sediments (Cole and Wells, 2015). The values used for these parameters are listed in table 4. With such complex interactions, especially when simultaneously trying to dynamically model algal communities, several hundred iterations were required for both of the final lake CE-QUAL-W2 models.

With varying success, the Madison Lake and Pearl Lake models captured the trajectories of DO concentrations at multiple depths over time, which indicated that the models were accurately simulating the underlying metabolic processes in each lake. Specific examples of the model capabilities presented in the following subsections include comparisons between simulated and measured vertical profile data for the midwater oxygen maximum earlier in the year for Madison Lake and the declining trend of DO with depth in Pearl Lake. Both cases illustrated that the internal trophic dynamics for these lakes are substantial factors affecting much of the observed biogeochemistry. 
$5 / 27 / 2014$

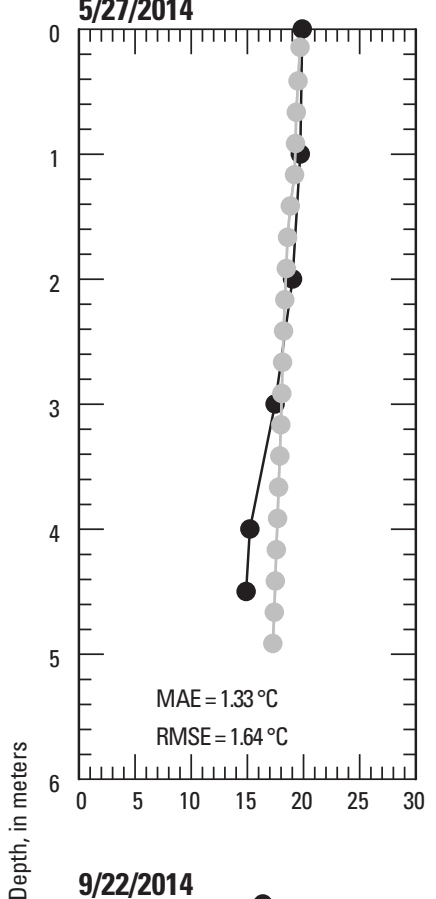

$6 / 24 / 2014$

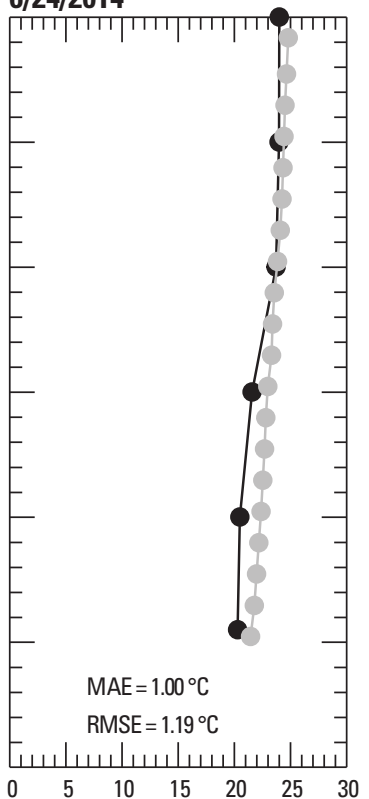

$10 / 27 / 2014$

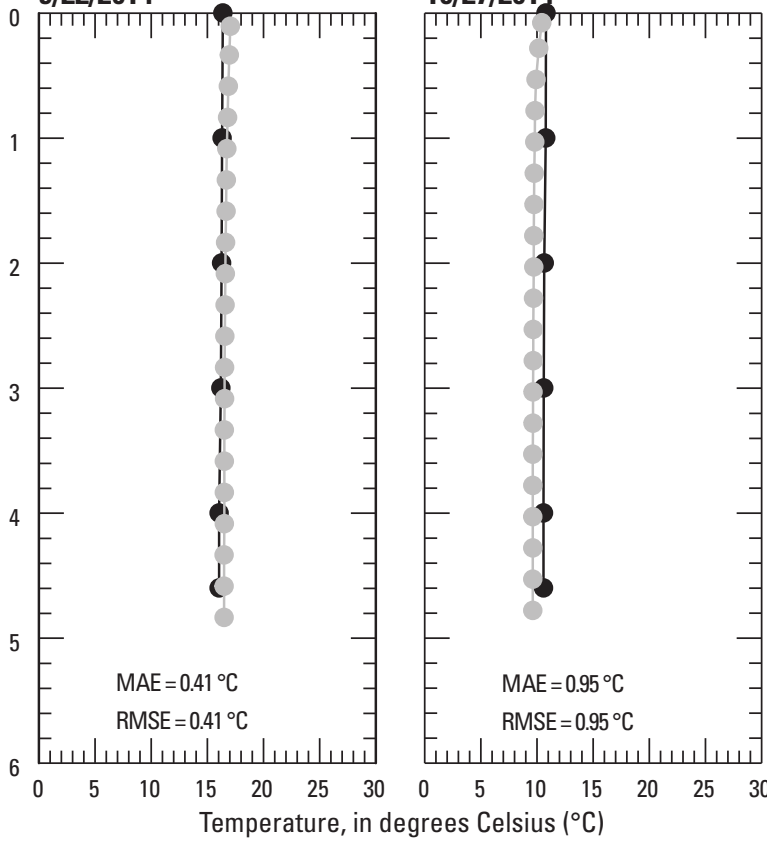

$7 / 23 / 2014$

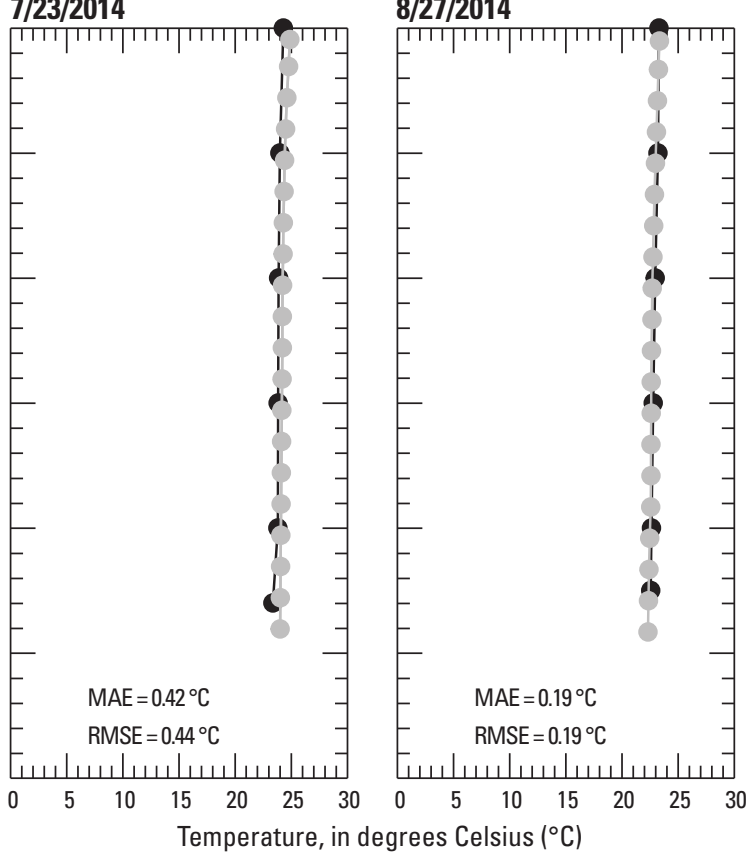

EXPLANATION
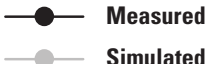

Figure 15. Simulated and measured water temperature for vertical profiles at Pearl Lake Deep Point near Marty, Minnesota, for six dates in 2014, with values of mean absolute error (MAE) and root mean square error (RMSE).

\section{Madison Lake}

For the DO calibration of the Madison Lake model, the principal calibration targets were the lake profile data from the southwest deep point site, available from monthly vertical DO profiles collected by MNDNR personnel during waterquality sampling trips in 2014. Generally, DO measurements were recorded for each meter below water surface. Simulated and measured DO concentrations are shown for a total of eight dates in figure 16. Overall, the simulated DO concentrations tracked the measured concentrations from the southwest deep point site. Generally, where the greatest change in DO occurred, the simulated concentrations matched the depth and slope of the measured concentrations. For example, the maximum midwater DO maximum between 3 and $6 \mathrm{~m}$ on May 29, 2014, showed little difference between the simulated and measured values as reflected with the low MAE and RMSE values $(<0.4 \mathrm{mg} / \mathrm{L})$. The same simulated maximum DO was still shown on June 3, but the measured values reflected more mixing from the surface to approximately $5 \mathrm{~m}$ by this time, causing larger MAE and RMSE values (greater than $1.0 \mathrm{mg} / \mathrm{L}$ ). Essentially, the simulated DO profiles preserved the greater midwater maximum on June 3 but also had a larger 
hypolimnetic oxygen deficit. The deterioration of the hypolimnetic oxygen levels occurred between May 29 and June 3; these minimal hypolimnion oxygen levels were maintained until sometime between the August 26 and September 17 DO profiles. By September 17, the lake began to overturn, as shown for DO (fig. 16) and lake water temperature (fig. 12). The simulated DO concentrations for September 17 were greater at depth, so the lake overturn started to occur 7 to
10 days earlier in the model than the measured lake values. With the last profile on October 15, the differences between the simulated and measured DO concentrations were close and consistently about $6 \mathrm{mg} / \mathrm{L}$ throughout the entire water column; the MAE and RMSE values for this date were 0.22 and $0.29 \mathrm{mg} / \mathrm{L}$, respectively (fig. 16). For the combined vertical profiles, the MAE and RMSE values were 0.68 and $1.15 \mathrm{mg} / \mathrm{L}$, respectively (table 5).
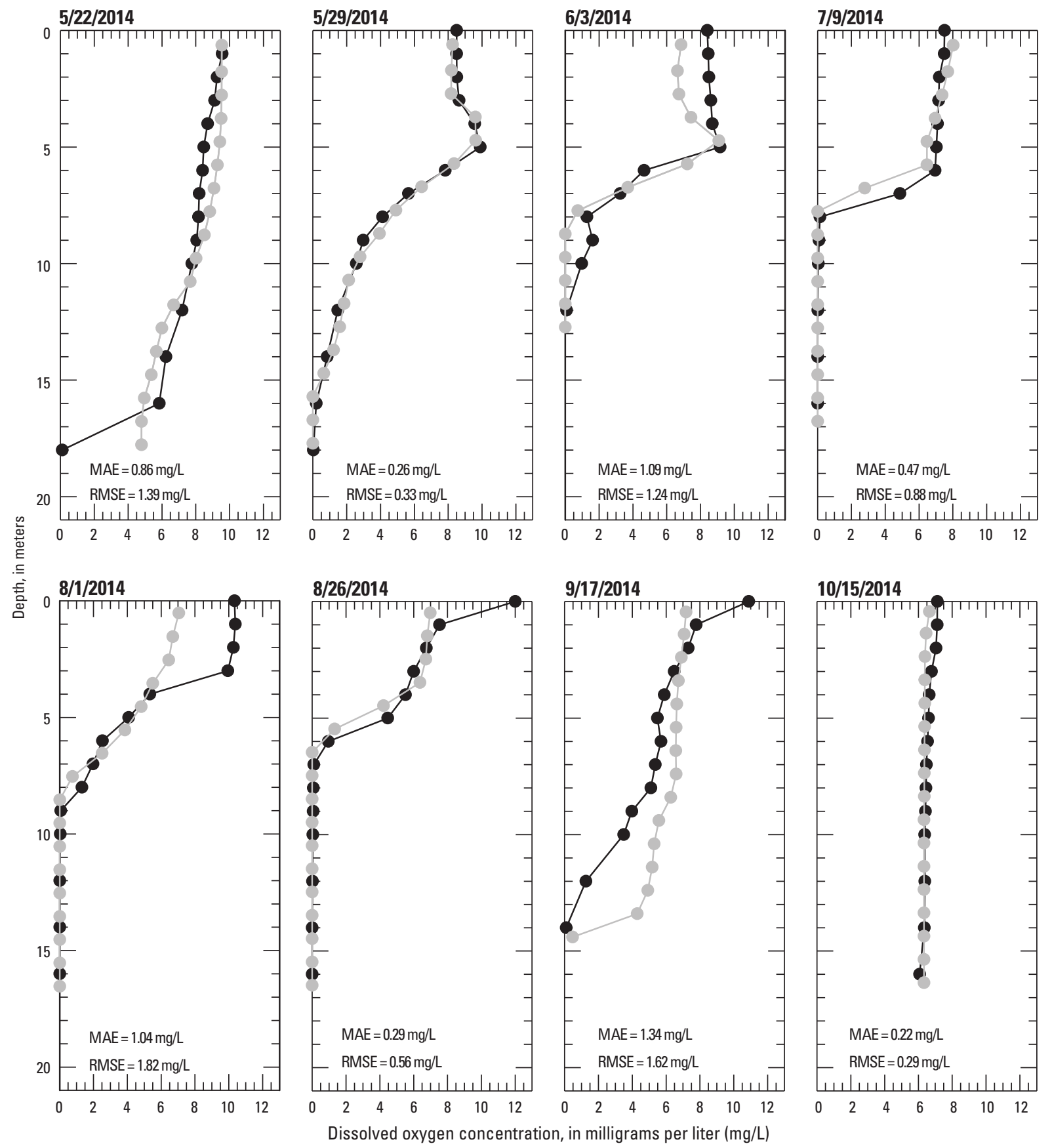

Figure 16. Simulated and measured dissolved oxygen concentration for vertical profiles at Madison Lake southwest deep point near Madison Lake, Minnesota, for eight dates in 2014, with values of mean absolute error (MAE) and root mean square error (RMSE).

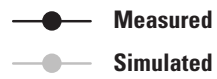


A complex interaction between processes has a strong effect on limnological DO concentrations. For example, increased algal production tends to increase lake DO concentrations, whereas heterotrophic consumption of the larger algal blooms increases oxygen demand (thereby depleting oxygen) (Wetzel, 2001). The decay rates of the different organic matter pools, such as parameters that control the labile, refractory, and the labile-to-refractory DO matter decay rates (parameters LDOMDK, RDOMDK, and LRDDK, respectively, in table 4), were low compared to previous rates used for other lake models such as Lake Carlos and Elk Lake (Smith and others, 2014); however, the organic matter decay rates were similar to rates used for Trout Lake (Smith and others, 2014). Decay rates have the strongest effect on the DO concentrations in the hypolimnion. Sediment oxygen demand (parameter SOD, table 4) also was large for Madison Lake, set at $2.5 \mathrm{mg} / \mathrm{L}$, which can greatly alter the DO profiles in the entire lake but particularly in the hypolimnion. The nitrate decay rate (parameter NO3DK, table 4) was set to 0.0575 per day, which is similar to the CE-QUAL-W2 default rate (Cole and Wells, 2015). Transitions between different algal communities affected DO, which are described in the "Algae" section. Algal dynamics played a large part in altering the DO dynamics, and given that Madison Lake calibration data existed for four different algal divisions (bacillariophyta/crysophyta [diatoms], chlorophyta [green algae], cyanophyta [blue-green algae], and haptophyta/ cryptophyta [flagellates]) (appendix table 2-1), a large effort was spent in the algal community calibration while preserving DO profile dynamics.

\section{Pearl Lake}

For the DO calibration of the Pearl Lake model, the principal calibration targets were the lake profile data from the Pearl Lake deep point site, available from monthly vertical DO profiles collected by MNDNR personnel during water-quality sampling trips in 2014. The DO measurements were recorded for each meter below the water surface. Simulated and measured DO concentrations are shown for a total of six dates in figure 17. Overall, the simulated DO concentrations were similar to the measured concentrations from the Pearl Lake deep point site, particularly the four profiles from July until October. Throughout the entire calibration period, simulated DO decreases with depth were restrained, which compared well to the measured data later in the year but caused large offsets for the first 2 months. The MAE and RMSE values were large on May 27 (2.81 and $2.92 \mathrm{mg} / \mathrm{L}$, respectively), and on June 24, the MAE and RMSE values were even larger (3.11 and $3.79 \mathrm{mg} / \mathrm{L}$, respectively). Later in the year, the simulated concentrations matched the depth and shallow slope of the measured DO concentrations, with MAE and RMSE values $<0.5 \mathrm{mg} / \mathrm{L}$. For the combined profiles, the MAE and RMSE values were 1.17 and $1.98 \mathrm{mg} / \mathrm{L}$, respectively (table 5); however, excluding the first two profiles, the MAE and RMSE values were 0.28 and $0.38 \mathrm{mg} / \mathrm{L}$, respectively.
Although the general trend towards slightly lower DO concentrations in the deeper portions of the mixed layer, and therefore the lake, was simulated by the model, several potential causes existed for the poor model fit for the May 27 and June 24 vertical DO profiles. These potential causes included the lack of simulated algal growth that would cause DO supersaturation in the shallower mixed layer, lack of organic matter decomposition in the deeper portions of the lake, inadequately low macrophyte respiration rates, large overwinter SOD, and thorough wind mixing of DO by the CE-QUAL-W2 model. Of the potential causes, simulated DO supersaturation in the shallow mixed layer was not supported by the measured algal biomass or chlorophyll $a$ concentrations. It was possible that an earlier bloom of green or blue-green algae was missed or not captured with the measured data, and therefore a greater algal biomass simulation of at least one of these groups would have caused larger DO values in the shallow mixed layer. Also, a quick die off of these early algal blooms would have quickly sank towards the bottom of the lake and caused organic matter decomposition, leading to simulated hypoxic to anoxic conditions that were measured in late May and June. The simulated DO also could have been better simulated with a greater initial concentration of organic matter in the lake, leading to more decomposition, but this was only weakly supported by the measured data. A third mechanism for better simulated DO profiles earlier in the year would be greater respiration rates for algae and macrophytes, which could be better explored with a calibration dataset of macrophyte growth. Large overwinter SOD also could cause measured DO concentrations well below the simulated concentrations because the model does not have the capability with the zeroorder SOD model to dynamically alter SOD rates. For some lakes with large organic matter decompositions, such as Pearl Lake, overwinter SOD can be very large before wind mixing fully mixes the lake (Cross and Summerfelt, 1987). The final mechanism that could explain the lack of fit earlier in the year is thorough wind mixing of DO by the CE-QUAL-W2 model. The ability of the model to simulate greater DO in the shallow mixed layer while simultaneously simulating hypoxic to anoxic conditions in the deeper mixed layer, in a shallow lake of only $5.5 \mathrm{~m}$, might be limited.

\section{Algae}

The paradigm of four general algal communities or groups was pursued rather than a more diverse speciesspecific modeling regime. This was partially because algal group calibration beyond four groups can be problematic for a CE-QUAL-W2 model given the sensitivity to algal group dynamics and the uncertainty in model parameterization beyond four different algal groups (Cole and Wells, 2015). The four algal groups or divisions included were (1) bacillariophyta and crysophyta (hereafter referred to as "diatoms"); (2) chlorophyta (green algae; hereafter referred to as "green 
algae"); (3) cyanophyta (blue-green algae; hereafter referred to as "blue-green algae"); and (4) haptophyta and cryptophyta (hereafter referred to as "flagellates"). Rather than including zooplankton as a separate group or groups, the zooplankton grazing dynamics were captured within algal specific constants such as the algal growth rate (parameter AG, table 4) and the algal mortality rate (parameter AM, table 4). Algal growth temperature ranges and the fractions of growth within the temperature ranges (parameters AT1 through AT4 and parameters AK1 through AK4, table 4) were different across all four algal groups, as were the algal growth rates (parameter $\mathrm{AG}$, table 4) and the light saturation intensities at the maximum photosynthetic rate (parameter ASAT, table 4). The main guidance for the algal groups was provided by other CE-QUAL-W2 modeling efforts, such as the previous sentinel lake models (Smith and others, 2014).

\section{Madison Lake}

The simulated distribution of four primary algal groups at $2 \mathrm{~m}$ below the water surface is shown in figure 18 for the model segment containing the southwest deep point site in Madison Lake (segment 7, fig. 2). Diatoms were the first group to peak, as shown with the Madison Lake simulated and

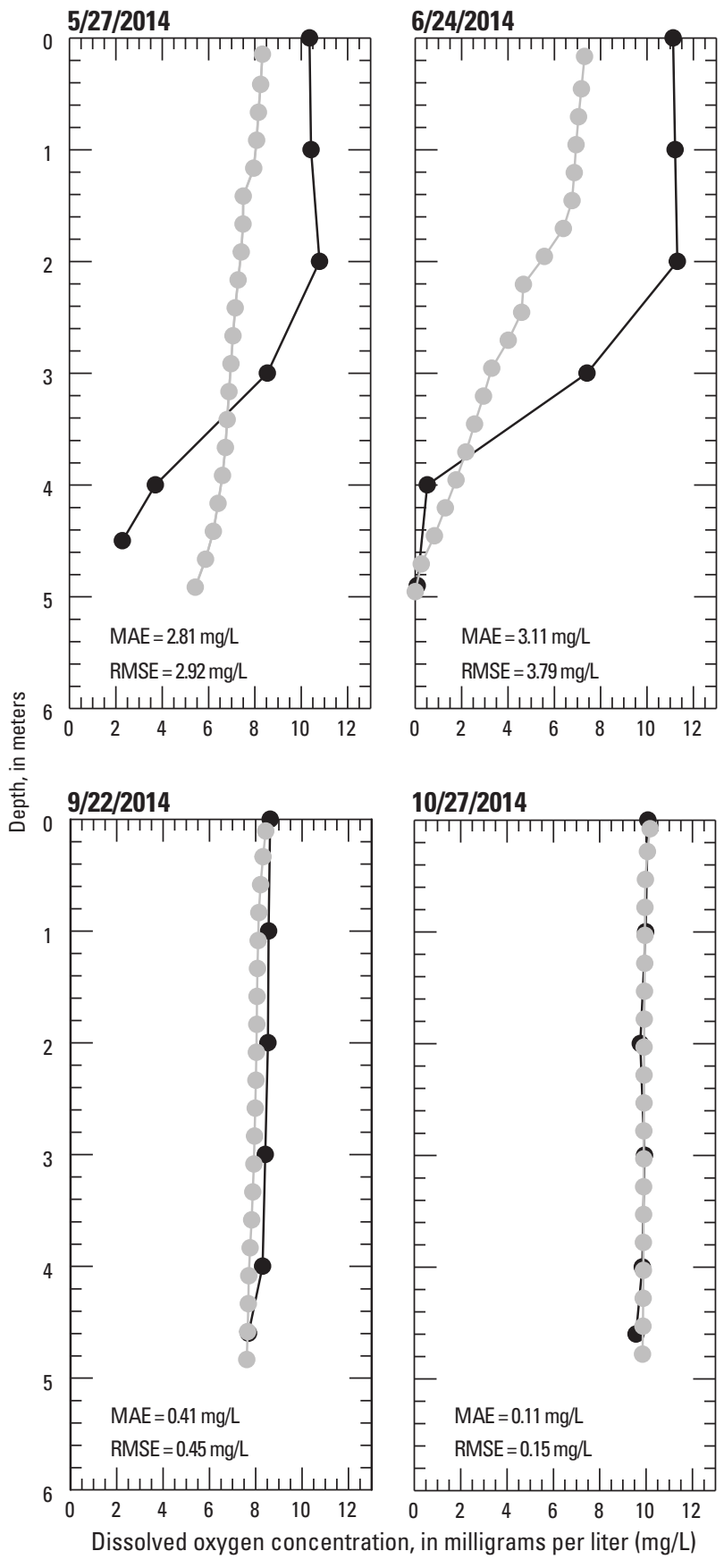

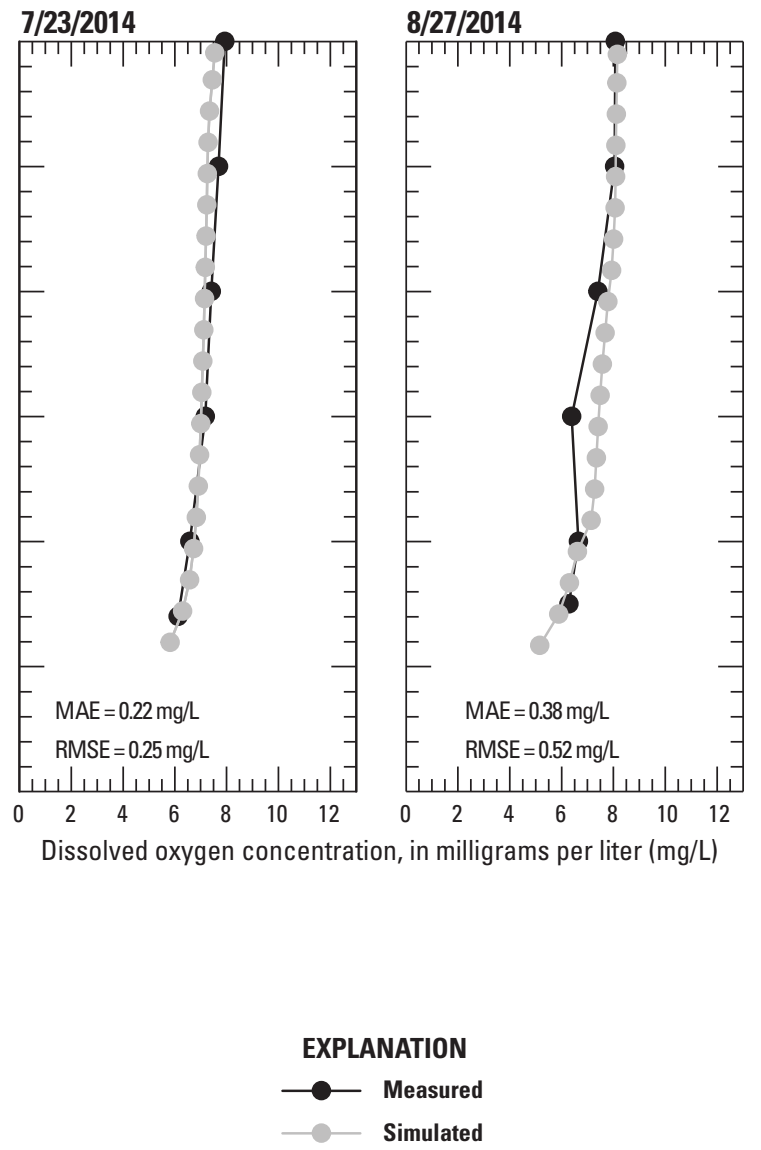

Figure 17. Simulated and measured dissolved oxygen concentration for vertical profiles at Pearl Lake Deep Point near Marty, Minnesota, for six dates in 2014, with values of mean absolute error (MAE) and root mean square error (RMSE). 
measured values. Diatoms commonly peak earlier in the year (Sigee, 2005). The simulated diatom values peaked by the end of May and then approached $0 \mathrm{mg} / \mathrm{L}$ by late June. For the measured values, a second peak occurred in late July and again in mid-September; however, the model did not capture these dynamics. Several factors controlled the lack of simulated diatom growth beyond early June, such as the growth rates that were tied to temperature ranges, the algal half-saturation constant for nitrogen-limited growth (parameter AHSN), the algal settling rate (parameter AS), and the algal light saturation intensity. The temperature range for diatom growth was lower than the other three algal groups, so once the lake warmed by early June, the diatoms were outcompeted by the other three groups. The larger algal light saturation intensity for diatoms, which affected optimal algal growth, limited growth once the lake had greater concentrations of inorganic and organic suspended sediments, macrophytes, and algal biomass and thereby blocked the light. Combined with a larger settling rate, the diatoms would settle to a depth in the lake unfavorable for optimal light saturation set in the model.

Blue-green algae were the next group to succeed the diatoms. Similar to the other three groups, blue-green algae were simulated as one group despite several different species measured in the lake; splitting this group into more specific groups could be warranted in future modeling efforts to better explain the blue-green algal succession. For this calibrated Madison Lake model, the blue-green algae were parameterized to allow for greater growth rates. The algal half-saturation constants for nitrogen-limited growth (parameter AHSN, table 4, 0.002)

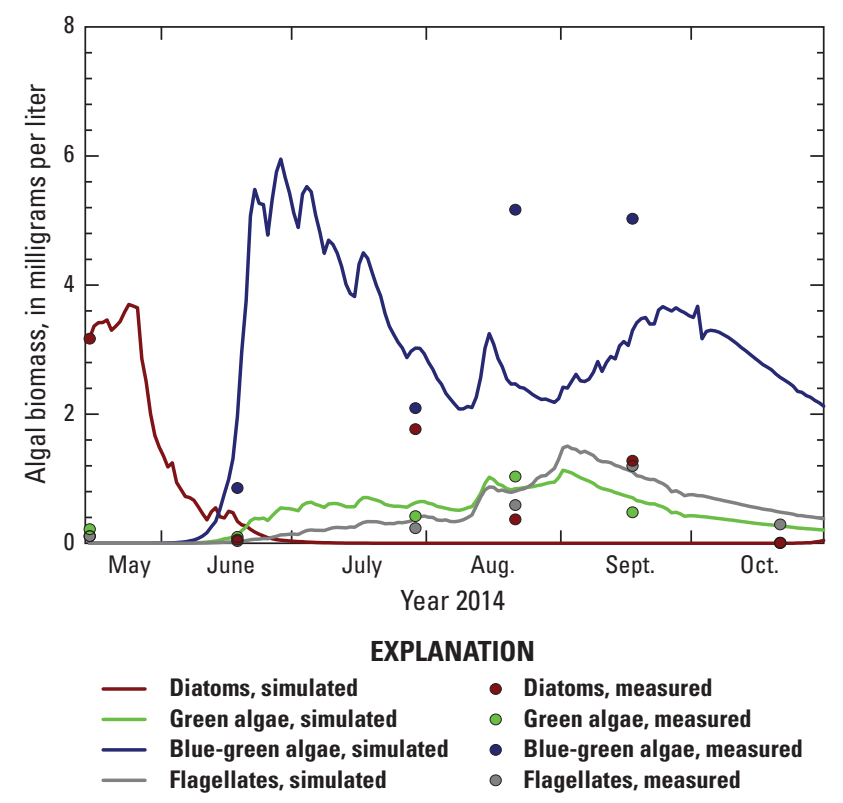

Figure 18. Simulated and measured algal group distributions (diatoms, green algae, blue-green algae, and flagellates) for the 2-meter depth at Madison Lake southwest deep point near Madison Lake, Minnesota, May 15 to November 1, 2014. were low relative to the other three groups, which ranged from 0.025 to 0.030 , and were one of the explanatory variables for the large simulated blue-green values throughout most of the calibration period (table 4). Also, the blue-green algae had a wide temperature range for maximum algal growth (between 20 and $32{ }^{\circ} \mathrm{C}$, table 4 ). The other three groups had narrow bands ranging from 4 to $6{ }^{\circ} \mathrm{C}$ wide. The blue-green algae also has a low algal light saturation intensity of 60 watts per square meter $\left(\mathrm{W} / \mathrm{m}^{2}\right)$, similar to green algae but much lower than $150 \mathrm{~W} / \mathrm{m}^{2}$ for the diatoms.

The other two algal community groups, green algae and flagellates, had similar growth rates and patterns for the simulated and measured values. The two groups were distinguished from each other in that the green algae showed a mid-August peak, whereas the flagellates showed a September peak (fig. 18). The maximum algal growth temperature range was similar for both groups, with 22 to $28^{\circ} \mathrm{C}$ and 24 to $28^{\circ} \mathrm{C}$ for the green algae and flagellates, respectively. Of the four groups, the flagellates had the lowest algal light saturation intensity of $20 \mathrm{~W} / \mathrm{m}^{2}$ (table 4). Otherwise, as shown in table 4, the parameterization of the two groups was similar for growth rate, algal mortality (parameter AM), and algal settling rate; and both groups had the same algal half-saturation constants for nitrogen- and phosphorus-limited growth (parameter AHSP).

Overall, the simulated algal biomass concentrations were similar to measured algal biomass concentrations with the exception of the previously described deviation for diatoms later in the year. Also, the simulated blue-green algal concentrations did not match the large measured values in August and September. Part of the discrepancy for both groups is that algal growth is known to vary considerably through time for phytoplankton groups in nature (Marañón and others, 2000); additionally, one sample point in time might not capture the general trend over time.

The chlorophyll $a$ concentration data were used to help interpret if the overall magnitude of the algal group composition was in the correct range. Photosynthetic pigments, such as chlorophyll $a$, are accepted in the literature as surrogates for algal biomass given the large expense of measuring algal biomass directly (Lindenberg and others, 2008). Simulated and measured values of the chlorophyll $a$ concentrations are shown for the Madison Lake southwest deep point site in figure 19 (segment 7, fig. 2); additionally, the simulated and measured values of the chlorophyll $a$ concentrations are shown for the northeast deep point site (segment 5, fig. 2). Measured chlorophyll $a$ data primarily were collected in the surface layer at approximately $2 \mathrm{~m}$ below the water surface as part of the monthly MNDNR water-quality sampling trips. Overall, the simulated values were a fairly good approximation of the measured values, although this was not reflected with the large MAE and RMSE values (fig. 19; table 5). The peak measured values for segment 5 in September were not captured by the model; additionally, the low measured chlorophyll $a$ concentrations in October were not captured by the model for either segment 5 or 7 . 


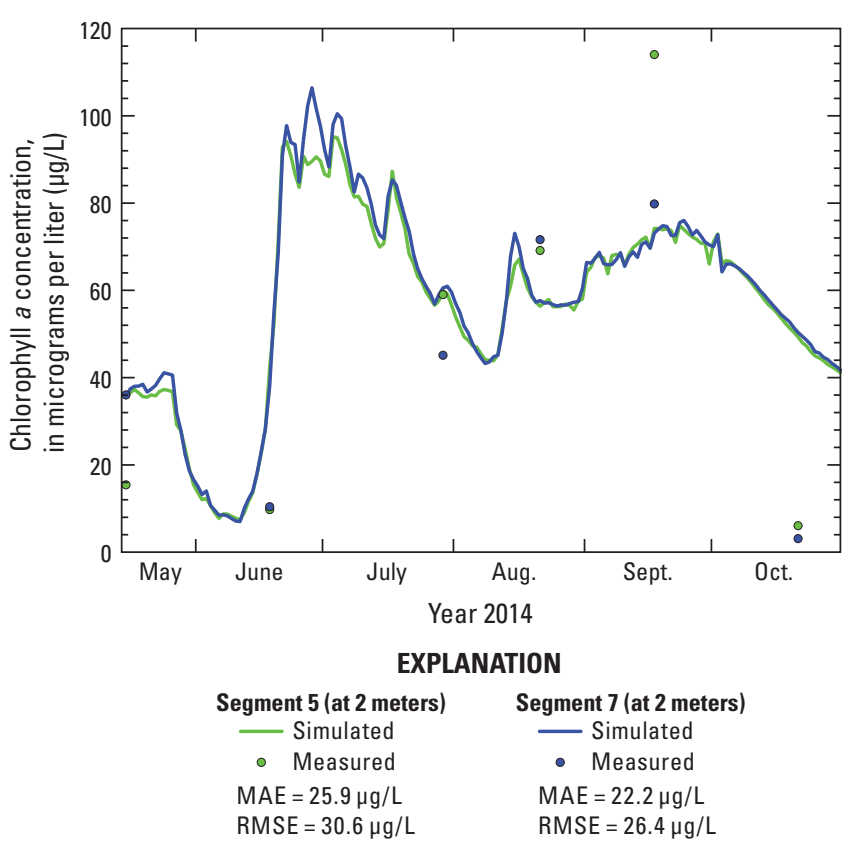

Figure 19. Simulated and measured chlorophyll a concentrations for the 2-meter depth at Madison Lake northeast deep point near Madison Lake, Minnesota, (segment 5) and Madison Lake southwest deep point near Madison Lake, Minnesota, (segment 7) in Madison Lake, May 15 to November 1, 2014.

\section{Pearl Lake}

The simulated distribution of four primary algal groups at $2 \mathrm{~m}$ below the water surface is shown in figure 20 for the model segment containing the Pearl Lake deep point site (segment 4, fig. 3). Compared to Madison Lake, Pearl Lake had a better fit between the simulated algal biomass to the measured algal biomass, as shown in figure 20 and indicated by the low MAE and RMSE values (table 5). The simulated distribution shows that all four groups started growing at approximately the same time period but at different rates. In Madison Lake, diatoms were the first group to peak, whereas in Pearl Lake, three of the four groups peaked at approximately $0.5 \mathrm{mg} / \mathrm{L}$ in early to mid-June, with the exception of a low abundance of green algae; however, the blue-green algae continue to peak and dominate the lake algal biomass for the entire summer, which also was supported with the measured algal biomass data. Green algae began to peak in mid-September, before beginning to disappear at approximately the same rate as bluegreen algae and the diatoms. The final group to peak, late in the simulation period, was the flagellates in early October.

Several factors controlled the dominance of the simulated blue-green algae; these factors also are potential explanations for the measured blue-green algae blooms. Pearl Lake, in comparison to Madison Lake, has greater clarity based on Secchi depths. The mean Secchi depth was $2.0 \mathrm{~m}$ for Pearl Lake in 2008-9 (Anderson and others, 2012), whereas the mean depth for Madison Lake was between 0.25 and $0.40 \mathrm{~m}$ in 2006 and 2008 (Lindon and others, 2010). With the greater light penetration during the summer months, the blue-green algae were parameterized as higher light specialists with the other three groups set up as low light specialists by adjusting the light saturation intensity (parameter ASAT, table 4). The blue-green algae had a large algal light saturation intensity of $120 \mathrm{~W} / \mathrm{m}^{2}$, compared to a range of 30 to $45 \mathrm{~W} / \mathrm{m}^{2}$ for the other three groups. The low algal half-saturation constants for blue-green algae for nitrogen-limited growth (0.002) relative to the other three groups, which ranged from 0.01 to 0.014 , is another possible factor explaining the large simulated blue-green values throughout most of the simulation cycle. Blue-green algae had a wide temperature range for maximum algal growth, between 17 and $28{ }^{\circ} \mathrm{C}$, which covered the lake water temperature range for most of the summer months.

Similar to Madison Lake, the chlorophyll $a$ concentration data for Pearl Lake were used as a secondary check on the simulated algal biomass concentrations. Simulated and measured values of the chlorophyll $a$ concentrations are shown in figure 21 for the Pearl Lake deep point site. The Pearl Lake chlorophyll $a$ data were collected with the same method and at the same depth ( $2 \mathrm{~m}$ below the water surface) as Madison Lake. Overall, the simulated values were a close approximation of the measured values, also reflected with the low MAE and RMSE values (fig. 21; table 5) of 0.93 and 1.16 micrograms per liter $(\mu \mathrm{g} / \mathrm{L})$, respectively.

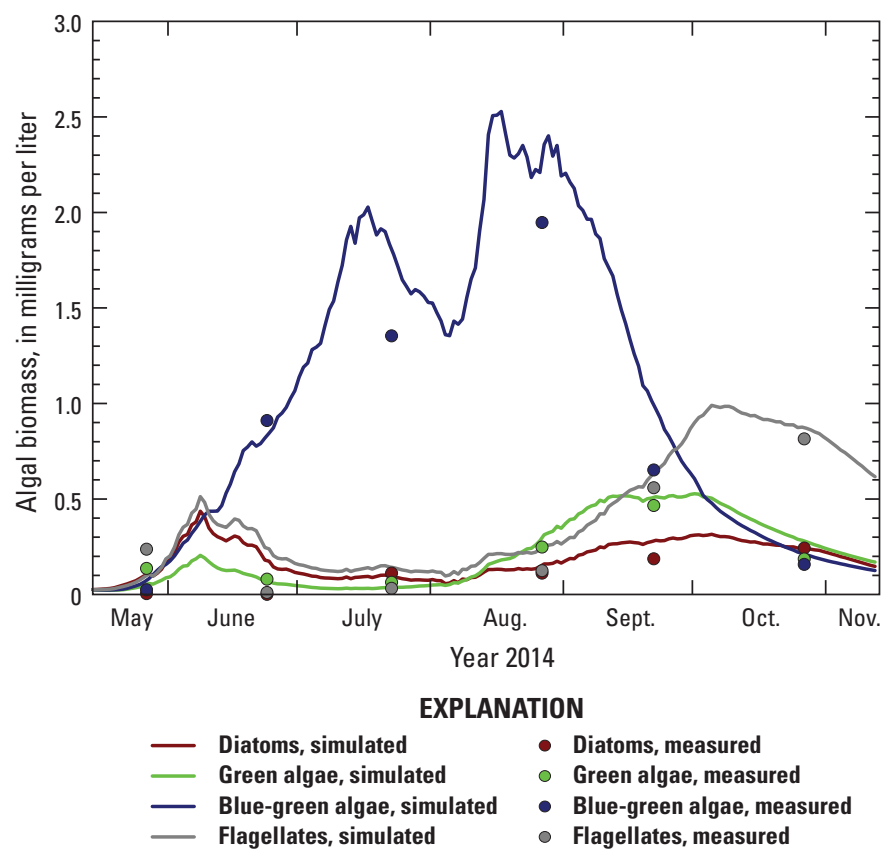

Figure 20. Simulated and measured algal group distributions (diatoms, green algae, blue-green algae, and flagellates) for the 2-meter depth at Pearl Lake Deep Point near Marty, Minnesota, May 14 to November 13, 2014. 


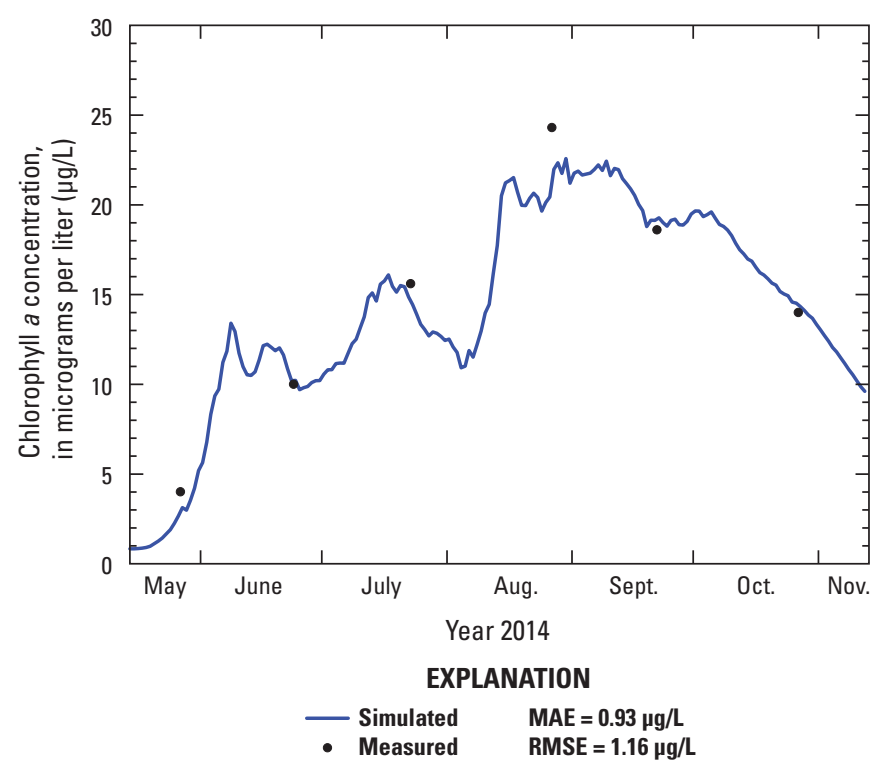

Figure 21. Simulated and measured chlorophyll a concentrations for the 2-meter depth at Pearl Lake Deep Point near Marty, Minnesota, May 14 to November 13, 2014, with values of mean absolute error (MAE) and root mean square error (RMSE).

\section{Macrophyte Growth}

For Madison Lake and Pearl Lake, the macrophyte growth model was run to account for the large macrophyte growth documented on both lakes (Lindon and others, 2010; Anderson and others, 2012). Although there was not a calibration dataset, inclusion of modeled macrophyte growth could account for more realistically simulated nutrient and DO dynamics. As shown in table 4, most of the macrophyte growth parameters were kept at default rates with the exception of the maximum macrophyte growth rate $(\mathrm{MG})$, the light saturation intensity at maximum photosynthetic rate (MSAT), and the fraction of macrophyte biomass that is converted to particulate organic matter after macrophytes die (MPOM). For Pearl Lake, a greater percentage of littoral area exists and has well-documented macrophyte communities throughout the lake (Anderson and others, 2012); therefore, these parameters were adjusted to allow for a greater amount of macrophyte growth in Pearl Lake in comparison to Madison Lake. In addition, with Madison Lake, the parameters were optimized in such a way to account for the greater macrophyte growth documented in the littoral areas (Lindon and others, 2010).

\section{Nutrients}

Nutrients in both lakes are controlled by many processes, such as inflow loads, algal production, and organic matter decay rates (Cole and Wells, 2015). One of the most important controls is the amount of nutrients (loads, determined in the model as concentration multiplied by streamflow and a unit conversion factor) contributed by the inflows, which are different for both lakes. Madison Lake had a larger flux of nitrate earlier in the season with a larger flux of ammonia later in the year, whereas Pearl Lake had a larger flux of nitrate mid-summer without the large mid-summer flux of ammonia. These loads would be expected to vary across ecoregions, with the soil fertility in the contributing drainage basin, and across different land uses (for example, row-crop agriculture compared to deciduous forest). In-lake processing of the nutrients is the major factor controlling nutrient concentrations. The focus for evaluating the model calibration was three constituents of nitrogen and two constituents of phosphorus: nitrate plus nitrite, ammonia, total Kjeldahl nitrogen, orthophosphate, and total phosphorus.

Sources and sinks are largely the same for both lakes. Madison Lake and Pearl Lake have fairly small flows from two different inflows and seem to have considerably large groundwater sources relative to surface inflows. Agricultural land use is the dominant land use at approximately 50 percent for the drainage areas for both lakes (Lindon and others, 2010; Anderson and others, 2012). An important distinction between the two agricultural lakes is the ratio of the drainage basin to lake area, which is 24:1 for Pearl Lake but only 4:1 for Madison Lake. Also, the forest land-use percentage is different between the two different lakes: the Pearl Lake drainage basin has a forest cover of 15 percent, whereas the Madison Lake drainage basin has a forest cover of 2 percent. Generally, basins with a larger percentage of forest or other undeveloped land cover will have lower nutrient loads relative to basins with a larger ratio of agricultural land use (U.S. Geological Survey, 1999).

For nitrate plus nitrite, sources include all inflows and ammonia nitrification; sinks include denitrification (in the water column and sediments), algal uptake, and lake outflow (Cole and Wells, 2015). For ammonia as nitrogen (ammonia $\left[\mathrm{NH}_{3}\right]$ and ammonium $\left[\mathrm{NH}_{4}^{+}\right]$), sources include all inflows, decay of all organic nitrogen pools, sediment release under anaerobic conditions, and algal respiration; sinks include nitrification, algal uptake, and lake outflow (Cole and Wells, 2015). For orthophosphate, sources include all inflows, decay of all organic matter pools, sediment release under anaerobic conditions, and algal respiration; sinks include particles settling with adsorbed phosphorus, algal uptake, and lake outflow (Cole and Wells, 2015). For purposes of comparing simulated and measured concentrations, total Kjeldahl nitrogen was classified as the concentration of nitrogen present in ammonia, nitrate plus nitrite, and organically bound nitrogen (in living algal biomass and all organic matter pools). For purposes of comparing simulated and measured concentrations, total phosphorus was classified as the concentration of phosphorus present in orthophosphate and bound up in organic matter (in living algal biomass and all organic matter pools).

The primary tools for evaluating the degree of fit for the nutrients were the MAE and RMSE values (table 5). It is worth noting that these values could often be largely offset by only one or two measured samples because of the small number of total discrete samples (five samples in Madison Lake and six samples in Pearl Lake). 


\section{Madison Lake}

Dissolved ammonia and dissolved nitrate plus nitrite distributions in Madison Lake were largely affected by the inflows and the lake hydrodynamics. The simulated and measured concentrations of dissolved ammonia as nitrogen at $2 \mathrm{~m}$ below the water surface are shown in figure 22 for the model segment containing the southwest deep point site in Madison Lake (segment 7, fig. 2). Few differences in the measured dissolved ammonia concentrations were noted among the epilimnion locations (2-m depth) in the lake from July through September. The measured value in June was greater than the mid- to late summer measured values, and the late October sample had the largest measured dissolved ammonia concentration for the entire year. Algal uptake of available ammonia was fairly rapid in the simulation and actual lake, with replenishment by organic matter decay and inflows. This process of algal uptake accounted for the lower dissolved ammonia concentrations during the middle of the simulation period for the simulated and measured values. Compared to earlier in the year, inflow loads were also low during the midto late summer period. Earlier in the year, algal growth rates in the simulation and the actual lake were not large enough to incorporate the available ammonia, so the simulated and the single measured values in June were greater than in May. Late in the model simulation, the simulation indicated that ammonia began to accumulate in the lake but could not account for the large concentration of $0.88 \mathrm{mg} / \mathrm{L}$ measured on October 21 . To account for this discrepancy, an adjustment could have been made to the stoichiometric equivalent of nitrogen for the different algal groups to artificially low values, the ammonia release rate from sediments could have been set higher, or the ammonia decay rate could have been lowered; however, any of these adjustments would have caused the other simulated values to be too large in comparison to the four other measured values. The MAE and RMSE values for dissolved ammonia were large compared to the other sentinel lake simulations (Smith and others, 2014), mostly due to the mismatch to the late October sample; the MAE and RMSE values were 0.18 and $0.31 \mathrm{mg} / \mathrm{L}$, respectively (fig. 22; table 5).

Simulated and measured dissolved nitrate plus nitrite concentrations are shown in figure 23 for the Madison Lake southwest deep point site. Additional nitrogen depletion was simulated for dissolved nitrate plus nitrite concentrations during the mid- to late summer period that only started to recover towards the end of the simulation period in October, although this was not supported by the measured data. The simulated increase in dissolved nitrate plus nitrite concentrations that occurred in early to mid-June was caused by greater nitrate concentrations in the two inflows and by ammonia nitrification of the earlier ammonia influx in the late spring. Towards the end of the simulation period, the dissolved nitrate plus nitrite concentration became increasingly depleted without a steady source of ammonia for nitrification, likely because of nitrate decay. The MAE and RMSE values for dissolved nitrate plus nitrite were 0.05 and $0.08 \mathrm{mg} / \mathrm{L}$, respectively (fig. 23; table 5), which are in line with previous calibrations for other sentinel lakes (Smith and others, 2014).

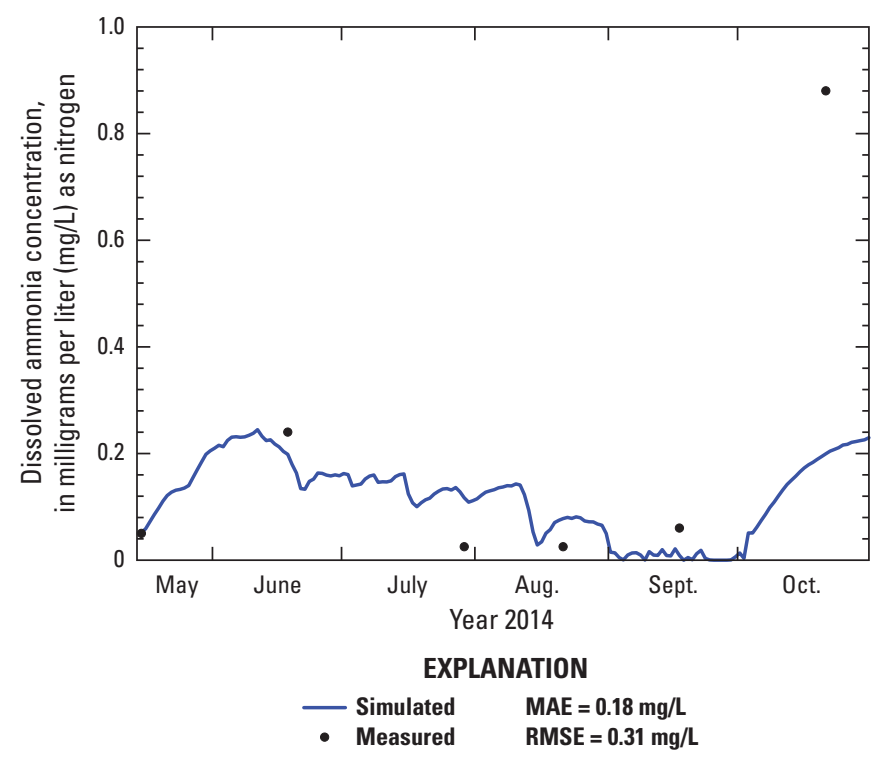

Figure 22. Simulated and measured dissolved ammonia concentrations at 2 meters below the water surface in model segment 7 containing the Madison Lake southwest deep point near Madison Lake, Minnesota, May 15 to November 1, 2014, with values of mean absolute error (MAE) and root mean square error (RMSE).

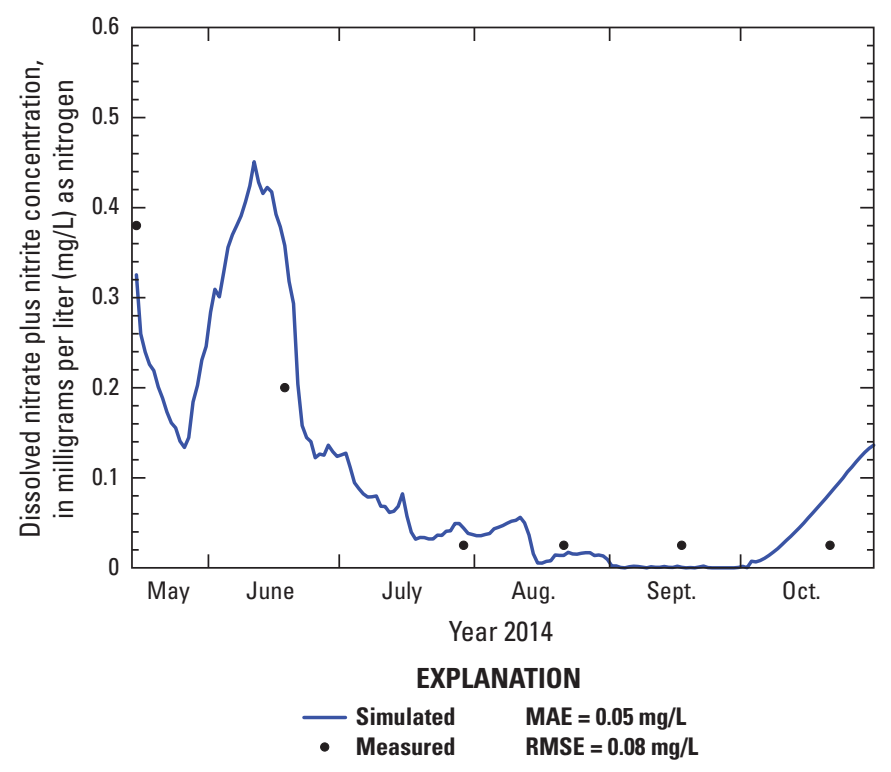

Figure 23. Simulated and measured dissolved nitrate plus nitrite concentrations at 2 meters below the water surface in model segment 7 containing the Madison Lake southwest deep point near Madison Lake, Minnesota, May 15 to November 1, 2014, with values of mean absolute error (MAE) and root mean square error (RMSE). 
Dissolved orthophosphate concentrations in the Madison Lake measured data were stable for most of the year (fig. 24). The simulated orthophosphate concentrations were considerably more variable due to the algal dynamics of the lake and the cycling of nutrients through the various organic pools, algal communities, and the lake's simulated macrophyte community. Also, despite replenishment by organic matter decay and inflows, algal uptake is fairly rapid; therefore, the succession through various algal communities with different phosphorus requirements would also cause variability. At the end of the simulation period, a steady increase in dissolved orthophosphate concentrations occurred primarily because of the lack of demand by algae and macrophytes. The MAE and RMSE values of 0.01 and $0.02 \mathrm{mg} / \mathrm{L}$, respectively, for dissolved orthophosphate were low overall because of the low concentrations with a good fit between the simulated and measured values (fig. 24; table 5).

Simulated and measured concentrations are shown for total Kjeldahl nitrogen in figure 25. The MAE and RMSE values for total Kjeldahl nitrogen were 0.29 and $0.33 \mathrm{mg} / \mathrm{L}$, respectively (fig. 25; table 5). The measured data indicate a fairly dynamic range, from approximately 1.4 to $2.2 \mathrm{mg} / \mathrm{L}$. A peak in total Kjeldahl nitrogen for the simulated values occurred in late June because of the increase in ammonia and nitrate concentrations, with a steady increase from late July through mid-September due to an accumulation in organic matter from the deterioration of algal biomass, macrophytes, and inflows. The simulated results were generally the same pattern as the measured total Kjeldahl nitrogen concentrations,

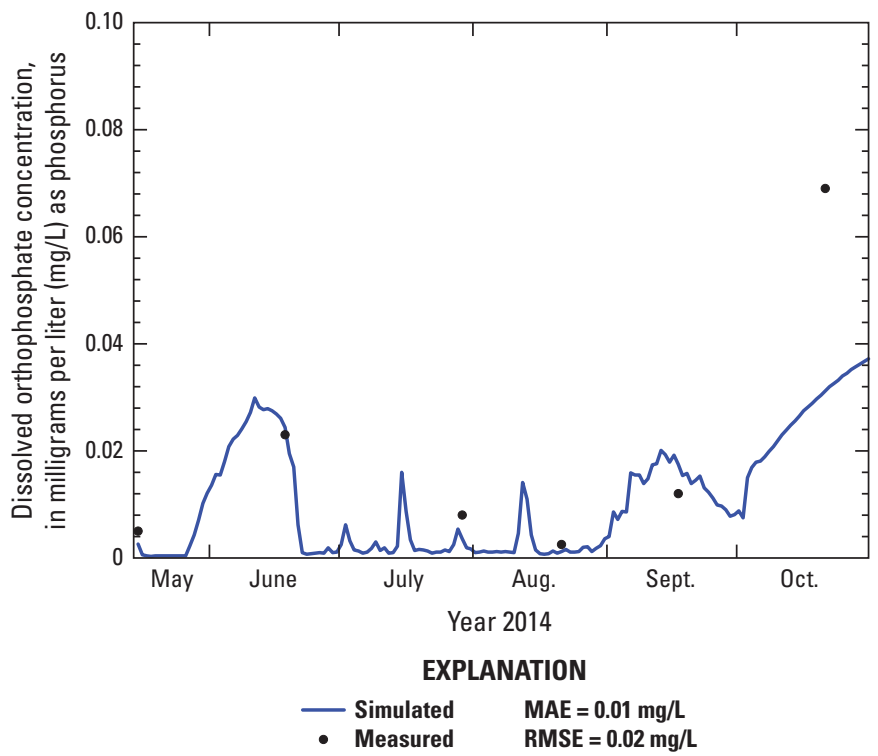

Figure 24. Simulated and measured dissolved orthophosphate concentrations at 2 meters below the water surface in model segment 7 containing the Madison Lake southwest deep point near Madison Lake, Minnesota, May 15 to November 1, 2014, with values of mean absolute error (MAE) and root mean square error (RMSE). with the exception of a steady decrease in total Kjeldahl nitrogen towards the end of the simulation period (fig. 25). This decrease was likely because of the overall decay of the simulated organic matter pools and the decrease in simulated total algal biomass.

Total phosphorus (fig. 26) was affected by the same factors as total Kjeldahl nitrogen but was a much smaller pool and an overall smaller portion of algal biomass; in the case of total phosphorus, the epilimnion and hypolimnion locations are shown because measured hypolimnion values were available for total phosphorus. In the epilimnion, the measured total phosphorus concentrations were stable but the simulated concentrations were too large. The model could have been fit to match the epilimnion concentrations better but would have sacrificed the hypolimnion phosphorus model fit with measured values and would have set phosphorus at unrealistically low stoichiometric equivalents for algal biomass and organic matter. In the hypolimnion, a steady and steep increase in total phosphorus occurred (greater than 1,100 $\mu \mathrm{g} / \mathrm{L}$ ) for the simulated and measured concentrations (fig. 26) throughout the simulation period starting in late May until mid-September, at which time the simulated and measured concentrations dropped precipitously to the baseline of approximately $130 \mu \mathrm{g} / \mathrm{L}$. The likely explanation for the large phosphorus concentrations in the simulated and measured values (fig. 26) was the large release rates in phosphorus from the lake sediments. The MAE values for the epilimnion (2-m depth) and hypolimnion (16.5-m depth) were 82 and $54 \mu \mathrm{g} / \mathrm{L}$, respectively; the RMSE values for the epilimnion (2-m depth) and hypolimnion

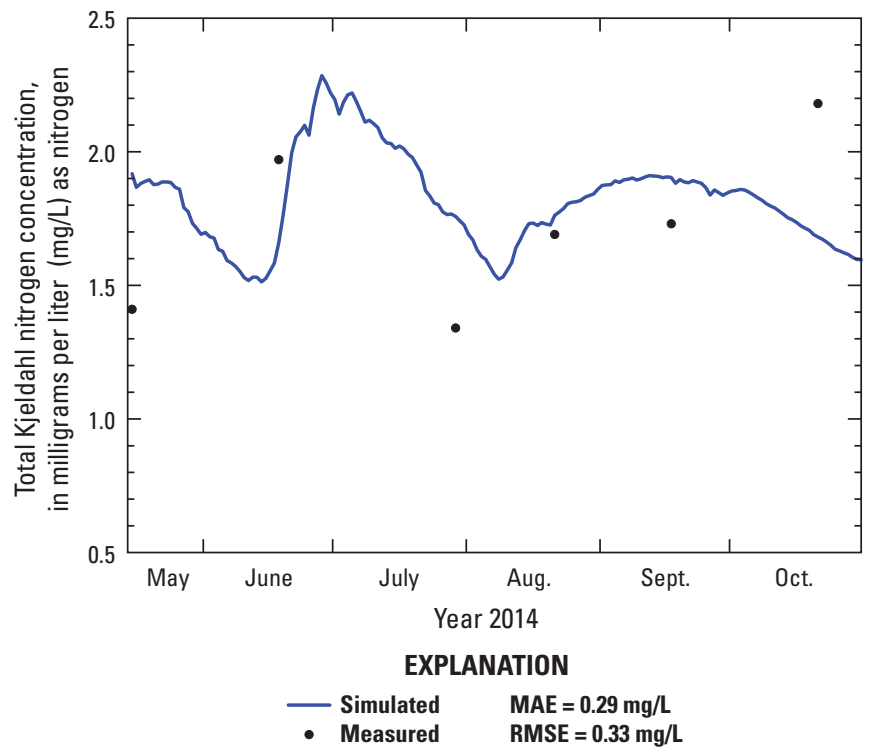

Figure 25. Simulated and measured total Kjeldahl nitrogen concentrations at 2 meters below the water surface in model segment 7 containing the Madison Lake southwest deep point near Madison Lake, Minnesota, May 15 to November 1, 2014, with values of mean absolute error (MAE) and root mean square error (RMSE). 
(16.5-m depth) were 86 and $69 \mu \mathrm{g} / \mathrm{L}$, respectively (fig. 26; table 5). The large drop in total phosphorus coincides with the turnover of Madison Lake and the mixing of all of the lake water, which redistributed the concentrated total phosphorus to the entire lake volume.

For Madison Lake, the large nutrient loads, particularly nitrate plus nitrite, were tied back to basin processes. Large nitrate plus nitrite loads from the two inflow sites and the distributed tributary flow (mainly groundwater) were the initial source of nitrate plus nitrite. Generally, basins with a large relative percentage of agricultural land use have larger concentrations of nitrogen and phosphorus species (Nolan and others, 1997; U.S. Geological Survey, 1999; Schilling and others, 2008). The small drainage basin to lake area of approximately 4:1 indicated that natural reduction processes for these nutrients were limited (Fraterrigo and Downing, 2008). Without heavily controlled agricultural best management practices to reduce these external loads, such as those practices highlighted in the Minnesota agricultural best management practices handbook (Minnesota Department of Agriculture, 2012), the receiving waters of the lake would likely have greater nitrate loads.

Once in the lake, combined with consistent delivery of other nutrients such as phosphorus, algal growth and the recycling of nutrients proceeded. As the algae and macrophytes died, the decomposition would liberate ammonia and other nutrients, leading to a feedback loop. In addition, as the decaying organic matter sank, the deeper mixed layer and the

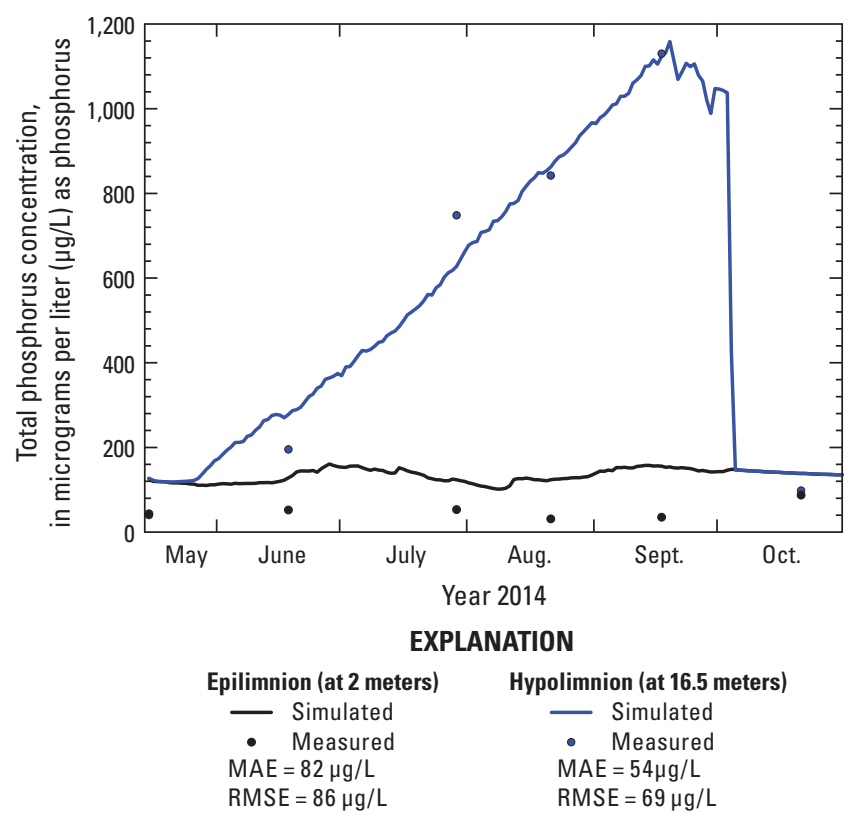

Figure 26. Simulated and measured total phosphorus concentrations at 2 meters and 16.5 meters below the water surface in model segment 7 containing the Madison Lake southwest deep point near Madison Lake, Minnesota, May 15 to November 1, 2014, with values of mean absolute error (MAE) and root mean square error (RMSE). hypolimnion became increasingly hypoxic. This caused the release of sediment-bound phosphorus that would initialize more algal growth. Between the external nutrient loading, internal nutrient loading from sediment release of phosphorus, and the organic matter decomposition of the algal and macrophyte biomass, even more algal and macrophyte growth was initiated. This recycling feedback between active growth and decomposition caused the series of algal blooms and the greater nutrient concentrations. Although ammonia, nitrate, and total Kjeldahl nitrogen generally decreased from the beginning of the simulation period to the end, total phosphorus in the hypolimnion continued to increase throughout most of the simulation period; however, lake overturn caused the phosphorus to become readsorbed and sink to the bottom of the lake, causing the total phosphorus concentrations in the lake to decrease, albeit the concentrations were greater than $130 \mu \mathrm{g} / \mathrm{L}$. At the total phosphorus peak, concentrations were greater than $1,000 \mu \mathrm{g} / \mathrm{L}(1 \mathrm{mg} / \mathrm{L})$. Because Madison Lake has a lake residence time on the order of 3-4 years (Lindon and others, 2010), this cycle has the potential to continue until drastic nutrient load reductions occur within the basin.

\section{Pearl Lake}

Dissolved ammonia and nitrate plus nitrite distributions in Pearl Lake were low compared to Madison Lake and largely affected by the algal growth dynamics. The simulated and measured concentrations of dissolved ammonia as nitrogen at $2 \mathrm{~m}$ below the water surface are shown in figure 27 for the model segment containing the Pearl Lake deep point site (segment 4, fig. 3). The measured dissolved ammonia

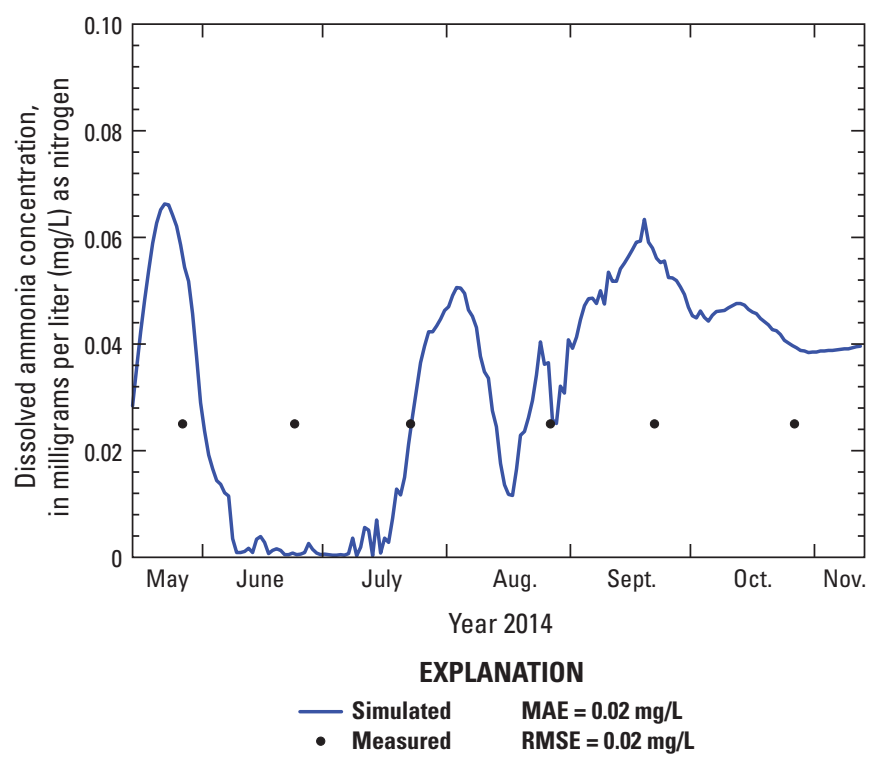

Figure 27. Simulated and measured ammonia concentrations at 2 meters below the water surface in model segment 4 containing the Pearl Lake Deep Point near Marty, Minnesota, May 14 to November 13, 2014, with values of mean absolute error (MAE) and root mean square error (RMSE). 
concentrations did not vary throughout the simulation period, whereas the simulated ammonia concentrations covered a range of from near zero to greater than $0.06 \mathrm{mg} / \mathrm{L}$. Similar to Madison Lake, algal uptake of available ammonia was fairly rapid in the simulation and actual lake measurements, with replenishment by organic matter decay and inflows. Because blue-green algae have lower nitrogen stoichiometric requirements (Williams and Burris, 1952), simulated ammonia concentrations did recover during certain periods in the summer months because the blue-green algae did not require as much nitrogen (part of their nitrogen requirements were incorporated from atmospheric nitrogen). The MAE and RMSE values for dissolved ammonia, both at $0.02 \mathrm{mg} / \mathrm{L}$, were low compared to Madison Lake (fig. 27; table 5).

Simulated and measured dissolved nitrate plus nitrite concentrations are shown in figure 28 for the Pearl Lake deep point site. Additional depletion was simulated for dissolved nitrate plus nitrite concentrations during the early summer period that only started to recover briefly in late July and again beginning in September. The simulated increase in dissolved nitrate plus nitrite concentrations that began in late July coincided with greater nitrate concentrations in the two inflows, particularly from the southwest corner inlet and the distributed tributary flow that was set up to mimic the incoming loads by way of the southwest corner inlet. Towards the end of the simulation period, the dissolved nitrate plus nitrite concentration steadily increased due to the slightly larger incoming concentrations (averaging between 2 and $3 \mathrm{mg} / \mathrm{L}$ ) and the steady source of nitrate from ammonia nitrification. The MAE and RMSE values for dissolved nitrate plus nitrite were 0.03 and $0.04 \mathrm{mg} / \mathrm{L}$, respectively, which are similar to previous calibrations for other sentinel lakes and the Madison Lake calibration (fig. 28; table 5).

Measured dissolved orthophosphate concentrations in Pearl Lake were low for the simulation period (fig. 29). The simulated orthophosphate concentrations, similar to Madison Lake, were dependent on the algal dynamics of the lake and the cycling of nutrients, particularly phosphorus, through the various organic pools, algal communities, and the lake's simulated macrophyte community. At the end of the simulation period, simulated and measured dissolved orthophosphate concentrations remained steady. The orthophosphate MAE and RMSE values were both $<0.01 \mathrm{mg} / \mathrm{L}$ because of the good fit and the low dissolved orthophosphate concentrations (fig. 29; table 5).

Simulated and measured concentrations are shown for total Kjeldahl nitrogen (fig. 30). The MAE and RMSE values for total Kjeldahl nitrogen were 0.17 and $0.19 \mathrm{mg} / \mathrm{L}$, respectively (fig. 30; table 5). The measured data indicate a less dynamic range than Madison Lake, from approximately 0.6 to $1.0 \mathrm{mg} / \mathrm{L}$. A peak in measured total Kjeldahl nitrogen concentrations occurred in late August and again in late October. The August peak nearly coincided with a simulated peak in total Kjeldahl nitrogen, whereas the late October peak occurred when the simulated total Kjeldahl nitrogen had a steady decrease towards the end of the simulation period. The simulated peak in total Kjeldahl nitrogen was mostly due to the simulated blue-green algae peak in late August; additionally, the steady decrease towards the end of the simulation coincides with the blue-green algae decrease.

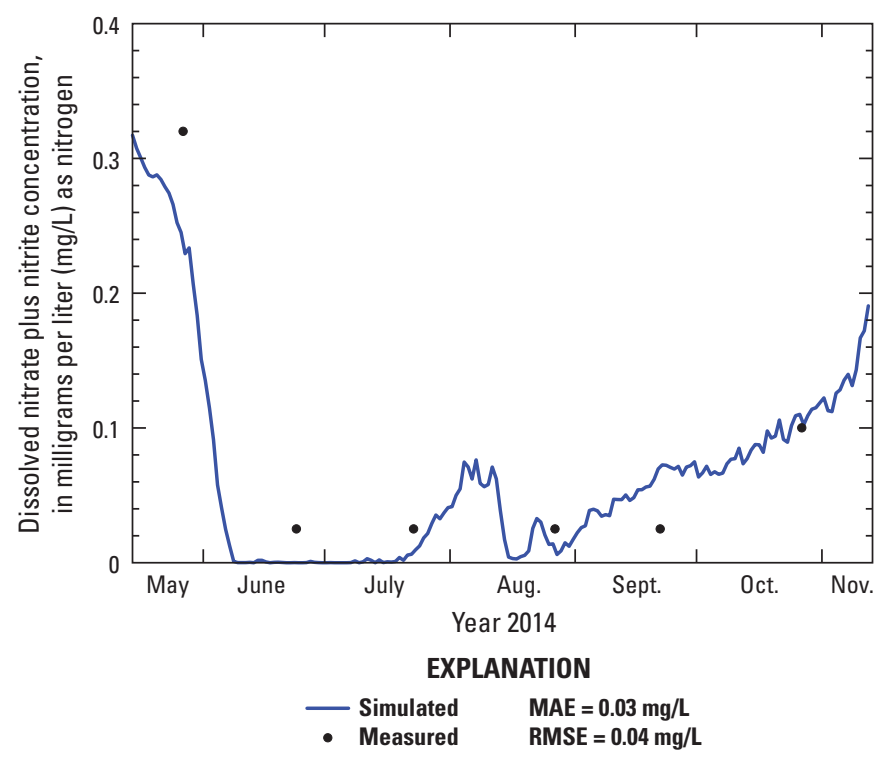

Figure 28. Simulated and measured nitrate plus nitrite concentrations at 2 meters below the water surface in model segment 4 containing the Pearl Lake Deep Point near Marty, Minnesota, May 14 to November 13, 2014, with values of mean absolute error (MAE) and root mean square error (RMSE).

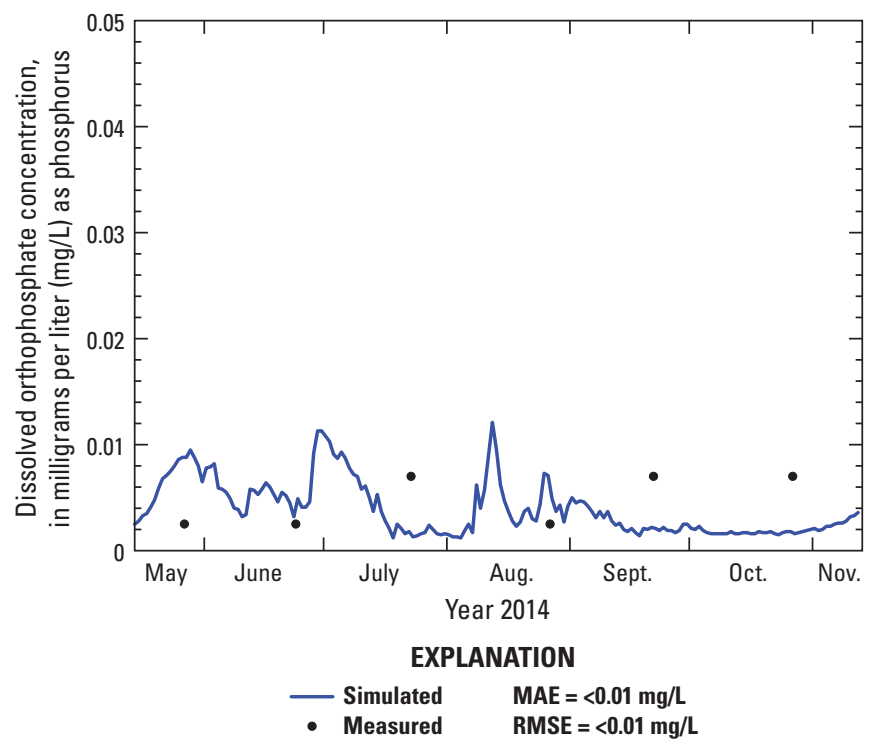

Figure 29. Simulated and measured orthophosphate concentrations at 2 meters below the water surface in model segment 4 containing the Pearl Lake Deep Point near Marty, Minnesota, May 14 to November 13, 2014, with values of mean absolute error (MAE) and root mean square error (RMSE). 


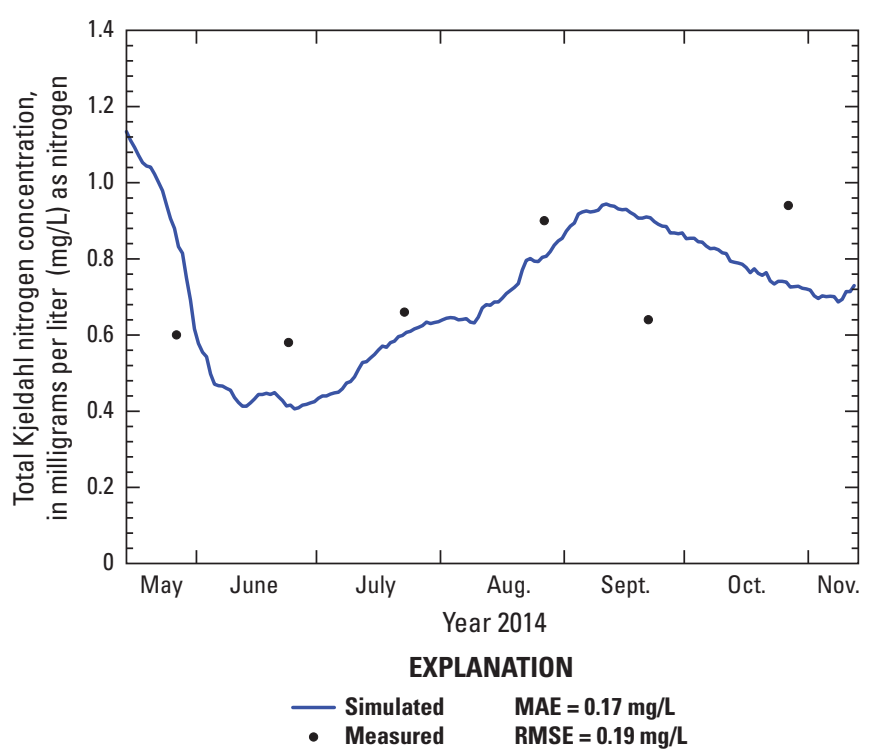

Figure 30. Simulated and measured total Kjeldahl nitrogen concentrations at 2 meters below the water surface in model segment 4 containing the Pearl Lake Deep Point near Marty, Minnesota, May 14 to November 13, 2014, with values of mean absolute error (MAE) and root mean square error (RMSE).

Measured total phosphorus concentrations were stable (between 10 and $20 \mu \mathrm{g} / \mathrm{L}$ ) in the shallow mixed layer at 2-m depth, with slightly greater simulated total phosphorus concentrations (fig. 31); however, the simulated total phosphorus concentrations did follow the general trend of the measured total phosphorus concentrations. In the deeper part of the mixed layer at $4.5-\mathrm{m}$ depth, the simulated total phosphorus concentrations do not capture the early peaks in measured total phosphorus concentrations of 34 and $65 \mu \mathrm{g} / \mathrm{L}$ for the May 27 and June 24 data collections, respectively. Larger total phosphorus concentrations in the deeper portion of the mixed layer earlier in the year would lend support to the theory of greater organic matter concentrations, as hypothesized in the "Dissolved Oxygen" section; however, without supporting evidence from a simultaneously collected total Kjeldahl nitrogen sample, it is not known if this was the cause of the greater measured total phosphorus concentrations. The MAE values for the shallow mixed layer (2-m depth) and deeper mixed layer (4.5-m depth) were 6 and $13 \mu \mathrm{g} / \mathrm{L}$, respectively; the RMSE values for the shallow mixed layer (2-m depth) and deeper mixed layer (4.5-m depth) were 7 and $17 \mu \mathrm{g} / \mathrm{L}$, respectively (fig. 31; table 5). Compared to Madison Lake, Pearl Lake did not have similar large total phosphorus concentrations.

Pearl Lake does not have nutrient concentrations as large as those present in Madison Lake. By presentation, many of the Pearl Lake figures appear to have large nutrient concentrations but the scales are smaller than those used for Madison Lake figures. Although external loading did provide nutrients to sustain greater algal growth and blue-green algae blooms, the differences in basin characteristics between the two lakes were likely a reason for the lower nutrient concentrations.

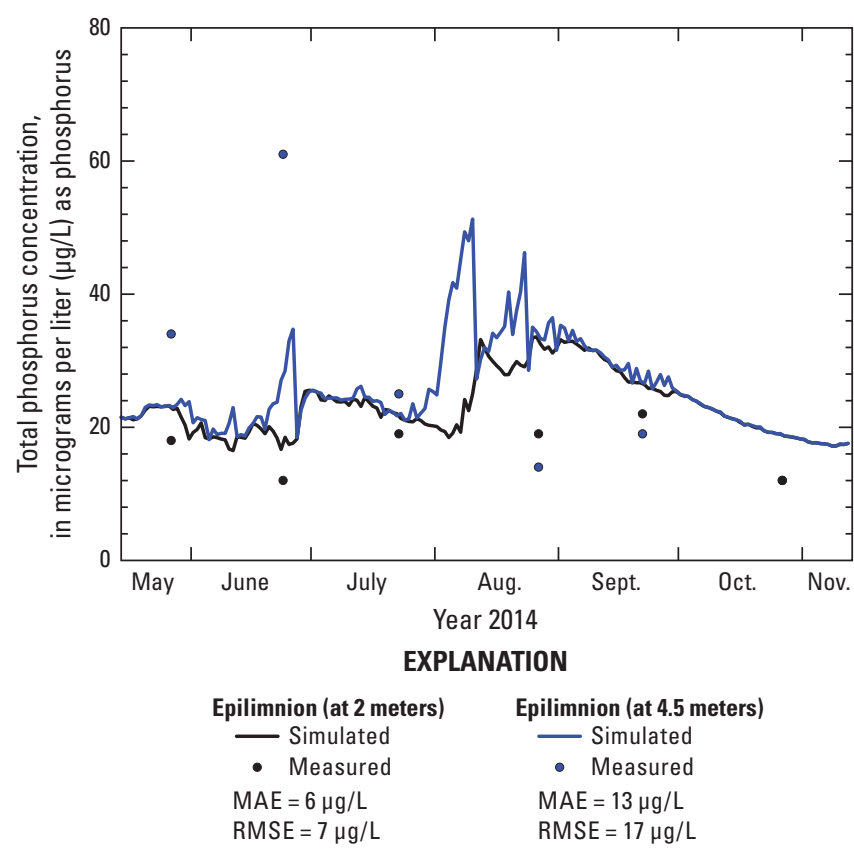

Figure 31. Simulated and measured total phosphorus concentrations at 2 meters and 4.5 meters below the water surface in model segment 4 containing the Pearl Lake Deep Point near Marty, Minnesota, May 14 to November 13, 2014, with values of mean absolute error (MAE) and root mean square error (RMSE).

Pearl Lake has a larger drainage basin to lake area ratio of 24:1, with approximately 15 percent forest cover. Additionally, for internal dynamics, the lake residence time is on the order of 1-2 years so the lake can conceivably cycle nutrients out of the lake faster. Although nutrient concentrations in Pearl Lake are smaller than those in Madison Lake, Pearl Lake has large nutrient concentrations that cause persistent blue-green algal blooms throughout the summer, as well as late-season green algae and flagellate blooms. Therefore, considerations in regards to basin management processes mentioned for Madison Lake, such as the necessity for external load reductions to limit algal blooms, also pertain to Pearl Lake.

\section{Model Limitations}

A full understanding of model limitations is necessary to better evaluate the performance of any water-quality model. Because the CE-QUAL-W2 model is laterally averaged, processes that could impose variations perpendicular to the primary flow axis of the lake will not be represented in the model. The CE-QUAL-W2 model vertically averages within a layer, although the discretization into 1-m (or smaller) segments likely is a sufficient representation of the vertical variability within the lake. Water-quality limitations include the simplification of a complex aquatic ecosystem into a series of kinetic reactions expressed in source and sink terms (Cole and Wells, 2015). Also, the fixed number of water-quality samples 
to which the model is calibrated may not have captured the full range of conditions in the dynamic systems. Specific water-quality modules within the CE-QUAL-W2 model have shortcomings that include the SOD, which is user-defined and is decoupled from the water column, and SOD variation only occurs with temperature. A complete sediment diagenesis model, with fully integrated sediment kinetics and the sediment-water interface, does currently exist within the CEQUAL-W2 V4.0 model; however, without adequate physical measurements, the complete sediment diagenesis model is not recommended for usage (Cole and Wells, 2015). The zooplankton module was also not included in this study because of sparse data during the calibration period; instead, the zooplankton effects were accounted for within the parameterization scheme of SOD and the algal dynamics as an attempt to address this deficiency.

Not only do data limitations exist, but structural selections such as segment geometry, the number of vertical layers, and the numerical transport scheme can potentially impose a bias in the outcome of the model. Boundary conditions are not fixed in nature but are limited in model development by the availability of data. In addition, extrapolation of the data was necessary to fit the requirements of the CE-QUAL-W2 model. For example, water-quality data were linearly interpolated between sampling dates.

\section{Fish Habitat Suitability for Cool-Water and Warm-Water Species}

Models frequently are used to simulate fish responses to changes in climate and land-use patterns. For example, statistically based models have used predicted climatic data and land-use data to demonstrate habitat losses that could cause localized extinctions of smallmouth bass in midwestern, largeriver, flood-plain ecosystems (Peterson and Kwak, 1999). In Minnesota, fish thermal and DO-based habitats were simulated in lakes over a range of current and proposed climate change scenarios using the MINLAKE96 program (Fang and others, 1999). Fang and others (1999) used good-growth habitat areas and good-growth habitat volumes as metrics to evaluate habitat units on a normalized scale, and the results demonstrated that fish habitat parameters depended more strongly on geometry and less on trophic state in inland, temperate lakes; however, the MINLAKE96 program does not use a carbonbased, trophic-dynamic model to predict fish habitat change nor does it include basin effects.

The CE-QUAL-W2 model, however, can be used to simulate biological responses to changing environmental conditions. Researchers have used the CE-QUAL-W2 model to simulate distribution and survival of white sturgeon over varying hydrologic conditions (Sullivan and others, 2003), the movements of blueback herring in a southern impoundment
(Nestler and others, 2002), as well as ongoing work by the USGS to simulate cisco habitat in Minnesota lakes under varying conditions of climate and nutrient loading (Smith and Kiesling, 2016).

In order to evaluate fish lake habitat suitability for coolwater and warm-water species, the CE-QUAL-W2 model results were evaluated for total volume of good-growth habitat (a lower and upper good-growth range), optimal growth habitat, and lethal oxythermal habitat. These sometimes overlapping ranges were developed from guidance in Fang and others (1999). The evaluation criteria given in this report were based on the mean range given in Fang and others (1999), which was developed from the earlier work of Eaton and others (1995) and based on entire fish guilds grouped into cold water, cool water, and warm water. For Madison and Pearl Lakes, examples of important cool-water fish, particularly game fish, include northern pike (Esox lucius), walleye (Sander vitreus), and black crappie (Pomoxis nigromaculatus) (Minnesota Department of Natural Resources, 2016c, 2016d). Examples of important warm-water fish include bluegill (Lepomis macrochirus), largemouth bass (Micropterus salmoides), and smallmouth bass (Micropterus dolomieu) (Minnesota Department of Natural Resources, 2016c, 2016d).

Lower cool-water good-growth habitat was defined as between 13.2 and $18.2^{\circ} \mathrm{C}$, upper cool-water good-growth habitat was defined as 27.7 to $28.8^{\circ} \mathrm{C}$, optimal cool-water growth habitat was defined as between 24.0 and $25.7^{\circ} \mathrm{C}$, and the lethal temperature range was set to above $28.0^{\circ} \mathrm{C}$. For all of the different ranges for cool-water fish, the DO minimum was set at $3 \mathrm{mg} / \mathrm{L}$. Lower warm-water good-growth habitat was defined as between 17.7 and $22.5^{\circ} \mathrm{C}$, upper warm-water good-growth habitat was defined as 31.3 to $34.7^{\circ} \mathrm{C}$, optimal warm-water growth habitat was defined as between 27.0 and $32.0^{\circ} \mathrm{C}$, and the lethal temperature range was set to above $32.3^{\circ} \mathrm{C}$. For all of the different ranges for warm-water fish, the DO minimum was set at $2.5 \mathrm{mg} / \mathrm{L}$; all of the limits were based on the work from Fang and others (1999). Sustained temperatures beginning at the high end of the upper good-growth habitat temperature ranges, combined with low DO, can be lethal.

\section{Madison Lake}

The combined good-growth (lower and upper) and optimal growth habitats for cool-water fish during the simulation period from May 15 to November 1, 2014, are shown in figure 32. Mainly due to the temperature requirements for these ranges, good-growth habitat range was limited to outside of the months of July and August. After mid-June and before early September, optimal growth habitat existed in as much as about 70 percent of the lake volume according to the criteria. Although much of the lower lake depths were hypoxic, most of the lake volume was under favorable DO conditions and would cross into optimal growth habitat during the warmer periods of the summer. 


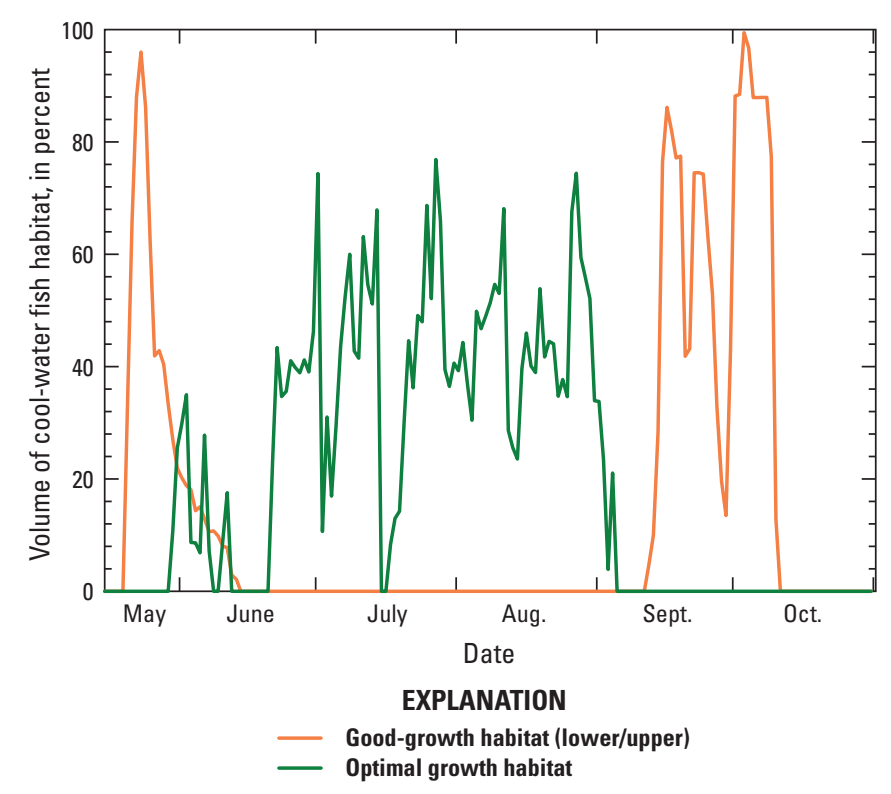

Figure 32. Good-growth (combined lower and upper ranges) and optimal growth habitat, by percentage of total lake volume, for cool-water fish in Madison Lake, May 15 to November 1, 2014.

The combined good-growth (lower and upper) and optimal growth habitats for warm-water fish during the simulation period from May 15 to November 1, 2014, are shown in figure 33. Much of the lake did contain good-growth habitat through mid-June and again after early September; however, unlike the cool-water fish, optimal growth habitat was sparse, mainly because the lake is not warm enough for warm-water fish to thrive, at least by the criteria set by Fang and others (1999). For cool-water and warm-water fish, the lake volume did not contain any lethal oxythermal habitat.

\section{Pearl Lake}

The combined good-growth (lower and upper) and optimal growth habitats for cool-water fish during the simulation period from May 14 to November 13, 2014, are shown in figure 34. Mainly due to the temperature requirements for these ranges, the good-growth habitat range was limited to a short period in late May and approximately 3 weeks from mid-September to early October. From mid-June to the end of August, optimal growth habitat existed in as much as about 90 percent of the lake volume according to the criteria. Although small portions of lower lake depths were hypoxic, most of the lake volume was under favorable DO conditions and would cross into optimal growth habitat during the warmer periods of the summer.

The combined good-growth (lower and upper) and optimal growth habitats for warm-water fish during the simulation period from May 14 to November 13, 2014, are shown in

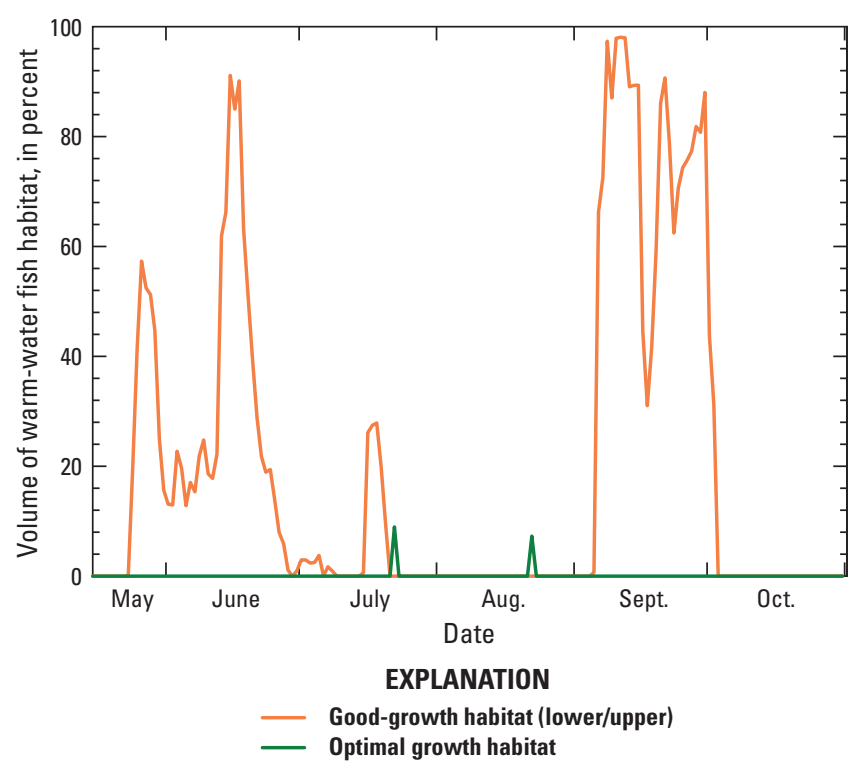

Figure 33. Good-growth (combined lower and upper ranges) and optimal growth habitat, by percentage of total lake volume, for warm-water fish in Madison Lake, May 15 to November 1, 2014.

figure 35. Much of the lake did contain good-growth habitat from mid-May through mid-July and again after late August, but little optimal growth habitat existed in Pearl Lake. Similar to Madison Lake, the lake volume did not contain any lethal oxythermal habitat for either cool-water or warm-water fish.

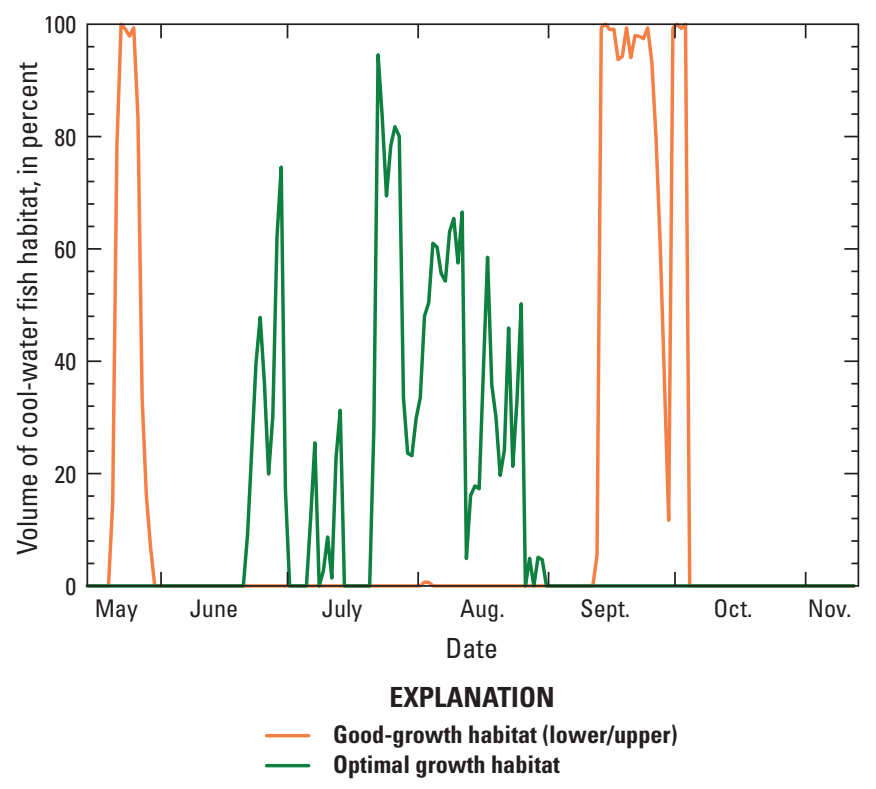

Figure 34. Good-growth (combined lower and upper ranges) and optimal growth habitat, by percentage of total lake volume, for cool-water fish in Pearl Lake, May 14 to November 13, 2014. 


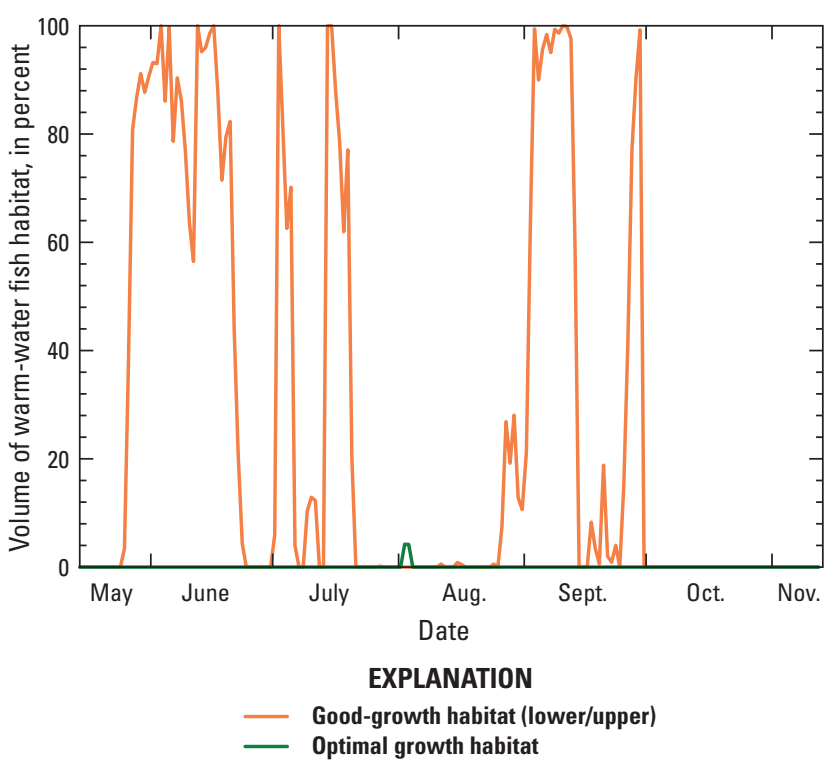

Figure 35. Good-growth (combined lower and upper ranges) and optimal growth habitat, by percentage of total lake volume, for warm-water fish in Pearl Lake, May 14 to November 13, 2014.

\section{Sensitivity Analysis}

A sensitivity analysis was completed to understand the effects of controlled departures in the calibrated model parameters and input nutrient loads on the model results. Because of the numerous calibrated parameters in both of the lake models (table 4), only seven different constituents were altered in the sensitivity analysis. For each of the following parameters or input loads, the calibrated lake model value was increased by 20 percent and decreased by 20 percent: WSC, inflow phosphorus, phosphorus sediment release rate, inflow nitrogen, inflow organic matter, SOD, and the extinction coefficient. In the case of the extinction coefficient, all of the component light extinction coefficients (table 4) were adjusted including the light extinction coefficients for pure water (parameter EXH20), inorganic suspended solids (parameter EXSS), organic suspended solids (parameter EXOM), the four different algal groups (diatoms [parameter EXA1], green algae [parameter EXA2], blue-green algae [parameter EXA3], and flagellates [parameter EXA4]), and the macrophyte coefficient (parameter EXM1). During model development and calibration, a more robust but less controlled sensitivity analysis was undertaken to attain a final calibrated model, meaning that more than these seven different constituents underwent sensitivity analysis; however, the seven constituents chosen for this analysis were determined to be some of the most sensitive parameters or input loads, which is similar to previous CE-QUAL-W2 lake models (Green and others, 2003; Sullivan and Rounds, 2004; Galloway and Green, 2006; Galloway and others, 2008; Smith and others, 2014).
With the exception of the WSC, six of the seven parameters or input loads were utilized to better understand the model response to parameters that can be directly affected by basin processes. These sensitivity analyses operated as land-use change scenarios because alterations in agricultural practices, for example, could potentially increase or decrease nutrient loads. Three of the seven parameters (inflow nitrogen, inflow organic matter, and inflow phosphorus) were related to input loads to the lake, so the connection to basin processes was more direct. Of the other four parameters, the following parameters have some indirect connections to basin processes: sediment release rates of phosphorus, SOD, and the extinction coefficients. The sediment release rate of phosphorus can be related to the available phosphorus in the sediments, which, if the available phosphorus was large due to legacy phosphorus loading (Marsden, 1989; James and others, 2015), under favorable conditions, more phosphorus can be released back into the water column. The SOD is the oxygen consumed by organisms in the sediment, so in shallow to moderately deep lakes rich in organic matter (such as eutrophic lakes), SOD can be large (Molongoski and Klug, 1980; Cross and Summerfelt, 1987), whereas in an oligotrophic lake this effect would not be as important. Extinction coefficients are related to light extinction caused by different solids in the water column, such as inorganic suspended solids, organic suspended solids, algal biomass, and macrophyte biomass (Cole and Wells, 2015). In a lake with larger concentrations of algal biomass, such as a eutrophic or hypereutrophic lake because of nutrient loading, extinction coefficients can be directly related back to basin processes (Carlson, 1977).

\section{Madison Lake}

Daily values for the southwest deep point site in Madison Lake (segment 7, fig. 2) were averaged into a single value for three different depths $(2 \mathrm{~m}, 5 \mathrm{~m}$, and $15 \mathrm{~m})$ for temperature and DO. The summary of the minimum, maximum, and median values of water temperature and DO for each of three depths is shown in table 6. Additionally, departures from the baseline (calibrated model) to the sensitivity analysis, shown as percent change from the baseline (calibrated) value, were completed for the following parameters with a 20-percent increase and a 20-percent decrease: WSC, inflow phosphorus, phosphorus sediment release rate, inflow nitrogen, inflow organic matter, SOD, and the extinction coefficient.

Water temperature in the Madison Lake was most sensitive to alterations in the WSC (table 6). The WSC adjusted the resultant wind speed, which affected the amount of mixing in the vertical dimension and thereby the depth of the thermocline over time. Decreases in the WSC resulted in lower wind speeds and led to a shallower thermocline and greater water temperatures at the lake surface. Increases in the WSC resulted in greater wind speeds and led to a deeper thermocline and lower water temperatures at the lake surface. 
Table 6. Summary of sensitivity analysis for water temperature and dissolved oxygen, in percent change from calibration run, for the segment containing the Madison Lake southwest deep point near Madison Lake, Minnesota, and the segment containing Pearl Lake Deep Point near Marty, Minnesota. The following depths are presented: 2 meters, 5 meters, and 15 meters (note: 15 meters only in Madison Lake). Also, the baseline (calibrated) values for the minimum, maximum, and median are shown for both lakes in the same segments.

[The following depths are shown: 2 meters, 5 meters, and 15 meters (note: 15 meters only in Madison Lake). Also, the baseline (calibrated) values for the minimum, maximum, and median are shown for both lakes in the same segments. mg/L, milligram per liter; --, not applicable]

\begin{tabular}{|c|c|c|c|c|c|c|c|}
\hline \multirow{2}{*}{ Parameter } & \multirow{2}{*}{$\begin{array}{l}\text { Input, in percent } \\
\text { change from } \\
\text { calibrated value }\end{array}$} & \multicolumn{3}{|c|}{ Water temperature (degrees Celsius) } & \multicolumn{3}{|c|}{ Dissolved oxygen (mg/L) } \\
\hline & & 2 meters & 5 meters & 15 meters & 2 meters & 5 meters & 15 meters \\
\hline \multicolumn{8}{|c|}{ Madison Lake } \\
\hline Baseline, minimum & -- & 9.5 & 9.5 & 9.5 & 4.5 & 0.0 & 0.0 \\
\hline Baseline, maximum & -- & 26.0 & 25.4 & 15.7 & 11.4 & 9.9 & 8.0 \\
\hline Baseline, median & -- & 23.0 & 21.5 & 14.5 & 7.1 & 6.2 & 0.0 \\
\hline \multirow[t]{2}{*}{ Wind sheltering coefficient } & -20 & 1.9 & -2.2 & -1.9 & 0.5 & -17.1 & -14.6 \\
\hline & +20 & -2.0 & -0.2 & 4.7 & -2.9 & 5.1 & 22.8 \\
\hline \multirow[t]{2}{*}{ Inflow phosphorus } & -20 & 0.0 & 0.0 & -0.0 & -0.7 & -0.2 & -0.7 \\
\hline & +20 & -0.0 & -0.1 & 0.0 & 0.7 & -0.0 & 0.4 \\
\hline Inflow nitrogen & +20 & -0.0 & -0.0 & 0.0 & -0.0 & -0.2 & -0.4 \\
\hline \multirow[t]{2}{*}{ Inflow organic matter } & -20 & 0.0 & -0.0 & 0.0 & 0.2 & 0.5 & 0.4 \\
\hline & +20 & -0.0 & -0.0 & 0.0 & -0.2 & -0.5 & -0.3 \\
\hline \multirow[t]{2}{*}{ Sediment oxygen demand } & -20 & 0.0 & 0.0 & -0.0 & 4.8 & 9.2 & 8.7 \\
\hline & +20 & -0.0 & -0.1 & 0.1 & -6.6 & -10.8 & -9.6 \\
\hline \multirow[t]{2}{*}{ Extinction coefficient } & -20 & 0.1 & 0.5 & -0.3 & 4.0 & 8.8 & 0.7 \\
\hline & +20 & -0.1 & -0.4 & 0.3 & -3.8 & -8.7 & -1.5 \\
\hline \multicolumn{8}{|c|}{ Pearl Lake } \\
\hline Baseline, minimum & -- & 2.2 & 2.2 & -- & 5.1 & 0.0 & -- \\
\hline \multicolumn{8}{|c|}{ Pearl Lake model output, in percent change from baseline (calibrated) value } \\
\hline \multirow[t]{2}{*}{ Wind sheltering coefficient } & -20 & 2.8 & 0.8 & -- & -1.6 & -21.1 & -- \\
\hline & +20 & -2.8 & -2.0 & -- & 1.8 & 12.0 & -- \\
\hline \multirow[t]{2}{*}{ Inflow phosphorus } & -20 & -0.0 & -0.0 & -- & -0.4 & -0.2 & -- \\
\hline & +20 & -0.0 & -0.0 & -- & 0.4 & 0.0 & -- \\
\hline \multirow[t]{2}{*}{ Sediment release rate, phosphorus } & -20 & -0.0 & -0.0 & -- & -0.8 & -0.1 & -- \\
\hline & +20 & 0.0 & -0.0 & -- & 0.8 & 0.2 & -- \\
\hline \multirow[t]{2}{*}{ Inflow nitrogen } & -20 & -0.1 & -0.1 & -- & 0.3 & 0.3 & -- \\
\hline & +20 & 0.0 & 0.0 & -- & -0.3 & -0.5 & -- \\
\hline \multirow[t]{2}{*}{ Inflow organic matter } & -20 & -0.0 & -0.0 & -- & 0.0 & 0.1 & -- \\
\hline & +20 & 0.0 & -0.0 & -- & -0.1 & -0.2 & -- \\
\hline \multirow[t]{2}{*}{ Sediment oxygen demand } & -20 & -0.1 & -0.0 & -- & 1.9 & 7.4 & -- \\
\hline & +20 & 0.0 & -0.0 & -- & -1.9 & -6.4 & -- \\
\hline \multirow[t]{2}{*}{ Extinction coefficient } & -20 & -0.6 & -0.2 & -- & -0.3 & 3.0 & -- \\
\hline & +20 & 0.2 & -0.0 & -- & -0.7 & -2.2 & -- \\
\hline
\end{tabular}


Perturbations in DO reflected the dynamic nature of DO as it is affected by many different processes, in particular alterations from the baseline (calibrated) model that affect algal growth dynamics. Dissolved oxygen was more sensitive than water temperature to alterations in the wind sheltering due to similar reasons as water temperature. Decreases in the WSC resulted in lower wind speeds and led to a shallower DO chemocline. Increases in the WSC resulted in more mixing of greater DO lake water near the surface to deeper parts of the mixed layer and into the hypolimnion, causing the DO chemocline to move deeper into the lake, particularly in July and early August. A 20-percent increase in the extinction coefficient caused a net decrease in DO for all three depths (table 6) because increases in the extinction coefficient had a negative effect on algal growth rates, causing less overall oxygen production. The late September blue-green algal bloom was most affected by this suppression of algal growth, having a two-fold effect: (1) less oxygen production in the shallow epilimnion;

(2) less organic matter decomposition in the hypolimnion, causing greater DO levels. Lowering the extinction coefficient by 20 percent, on the other hand, led to more algal growth of green algae and flagellates, which led to more epilimnion DO, although it did not seem to have much of an effect deep in the lake at $15 \mathrm{~m}$. Finally, SOD was a major sink for DO, with increases in SOD leading to lower DO concentrations and decreases in SOD leading to greater DO concentrations.

Nutrient concentrations were affected by several parameters or input loads (table 7). Dissolved ammonia and dissolved nitrate plus nitrite were most affected by increases in the WSC, inflow nitrogen, SOD, and the extinction coefficient (table 7). The increased WSC affected ammonia and nitrate as less algal growth, likely due to greater temperatures at the limit or beyond the maximum growth ranges, led to less photosynthesis (uptake) (fig. 36) and therefore larger ammonia pools (fig. 37). Declines in the WSC did not have as much of an effect on dissolved ammonia or dissolved nitrate plus nitrite, although an increase in dissolved ammonia did occur, which was due to an earlier season suppression of algal growth that caused a short-term increase in dissolved ammonia. Inflow nitrogen increases and decreases led directly to comparable increases or decreases in the dissolved ammonia and dissolved nitrate plus nitrite pools. An SOD increase led to less dissolved ammonia and dissolved nitrate plus nitrite, whereas SOD decreases led to even larger gains in both of those pools. Finally, the decrease in the extinction coefficient had a larger effect on dissolved ammonia and dissolved nitrate plus nitrite than an increase in the extinction coefficient. The greater light penetration with decreased extinction coefficients led to less blue-green algal growth, similar to the effects mentioned earlier; in this case, less algal growth led to less nutrient uptake.

Dissolved orthophosphate and total phosphorus tracked together in terms of the effects of the different sensitivity parameters (table 7), albeit at different percent changes because of the relative sizes of these pools. Dissolved orthophosphate was only a portion of the total phosphorus, so any percent change in orthophosphate was generally exaggerated in comparison to total phosphorus. Two sensitive parameters, although not as large as expected, were the changes in the sediment release rate of phosphorus and the changes in the inflow phosphorus. Dissolved orthophosphate and total phosphorus pools increased with a 20-percent increase in either of these two parameters, and both pools decreased with a 20 -percent decrease. Dissolved orthophosphate and total phosphorus pools were more sensitive to WSC, SOD, and the extinction coefficients. The WSC increase caused more phosphorus burial as lake overturn and mixing happened earlier in the year; a decrease in the WSC, and thereby wind energy, caused a shallower DO chemocline, which led to more phosphorus release into the water column (fig. 38). With SOD increases, more phosphorus was released into the water column and vice versa for SOD decreases. Dissolved orthophosphate was affected by extinction coefficient increases because less algal growth led to more orthophosphate in the water column.

\section{Pearl Lake}

Daily values for the Pearl Lake deep point site in Pearl Lake (segment 4, fig. 3) were averaged into a single value for two different depths $(2 \mathrm{~m}$ and $5 \mathrm{~m}$ ) for temperature and DO. The summary of the minimum, maximum, and median values of water temperature and DO for both of the depths is shown in table 6. Additionally, departures from the baseline (calibrated model) to the sensitivity analysis, indicated by percent change from the baseline (calibrated) value, were completed for the same parameters as used for Madison Lake.

Water temperature in the Pearl Lake was most sensitive to alterations in the WSC, mainly for the upper mixed layer. Decreases in the WSC resulted in lower wind speeds and led to a shallower thermocline and greater water temperatures at the lake surface. Increases in the WSC resulted in greater wind speeds and led to a deeper thermocline and lower water temperatures at the lake surface, which is a similar effect as indicated for Madison Lake.

Similar to Madison Lake, DO was more sensitive than water temperature to wind sheltering alterations. Decreases in the WSC resulted in lower wind speeds and led to a shallower DO chemocline. Less DO at $2 \mathrm{~m}$ was due to a substantial increase in blue-green algae (fig. 39) throughout the summer months, which eventually died off and caused massive organic matter decomposition in the deeper mixed layer. Increases in the WSC resulted in more mixing of greater DO lake water near the surface to the deeper mixed layer near the bottom of the lake. Of the remaining parameters, only SOD had a percent change greater than 5 percent, with increases in SOD leading to lower DO concentrations and decreases in SOD leading to greater DO concentrations (table 7).

Nutrient concentrations were affected by several parameters or input loads (table 7); however, compared to Madison Lake, these effects were subdued because the overall load into Pearl Lake and the internal lake dynamics were much smaller for nutrients. Dissolved ammonia and dissolved nitrate plus 
Table 7. Summary of sensitivity analysis for the water-quality parameters of dissolved orthophosphate, dissolved ammonia, dissolved nitrate plus nitrite, dissolved oxygen, and total phosphorus. Values shown are the percent change from the calibration run, based on the volume-weighted averages for the segment containing Madison Lake southwest deep point near Madison Lake, Minn. and the segment containing Pearl Lake Deep Point near Marty, Minn.

[Values shown are the percent change from the calibration run, based on the volume-weighted averages for the segment containing Southwest Deep Point in Madison Lake and the segment containing Pearl Lake Deep Point in Pearl Lake. Also, the baseline (calibrated) volume-weighted averages for the minimum, maximum, and median are shown for both lakes in the same segments. $\mathrm{mg} / \mathrm{L}$, milligram per liter; $\mu \mathrm{g} / \mathrm{L}$, microgram per liter]

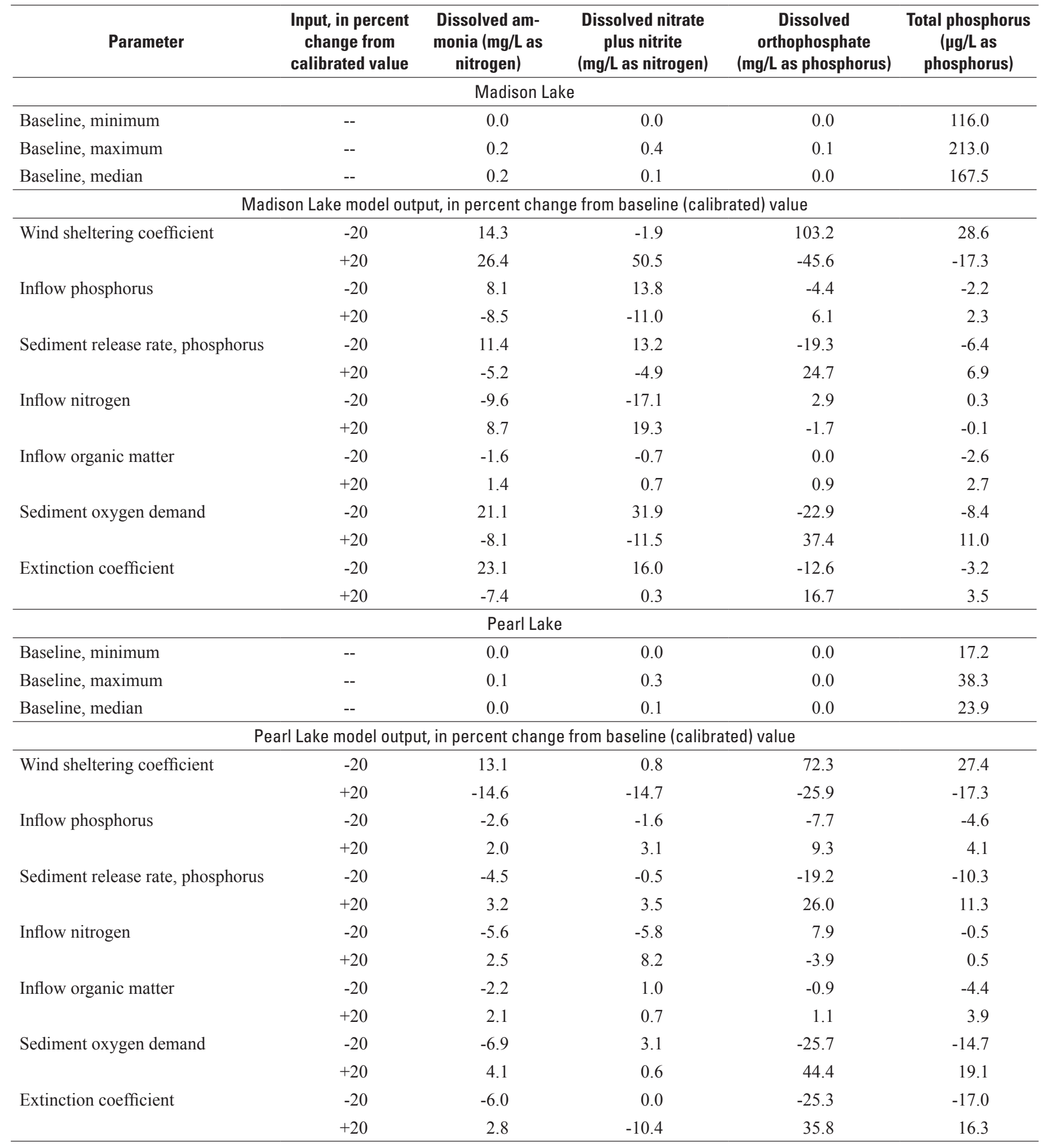




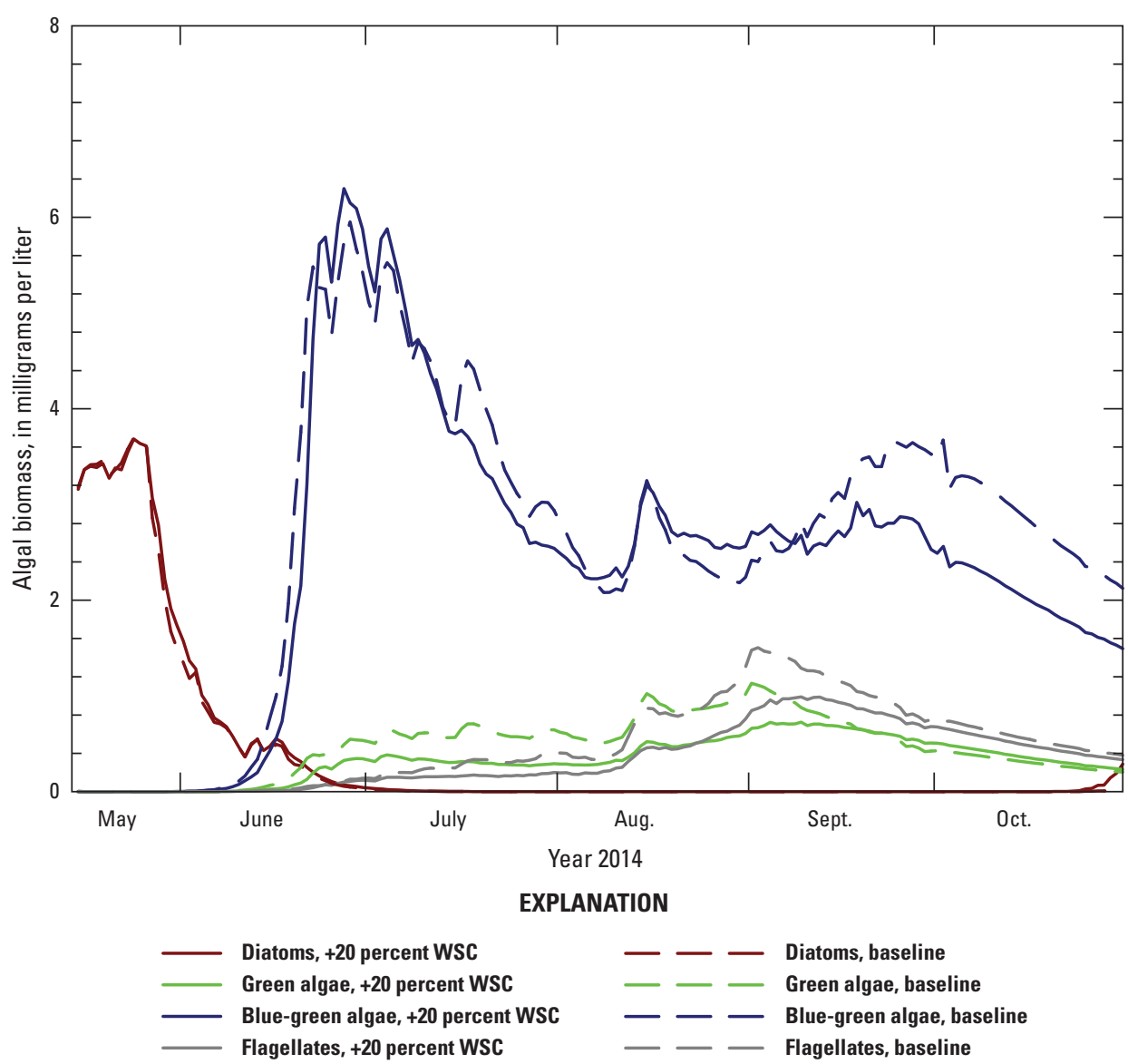

Figure 36. Simulated algal group distributions (diatoms, green algae, blue-green algae, and flagellates) for the 2-meter depth at the Madison Lake southwest deep point near Madison Lake, Minnesota, May 15 to November 1, 2014, with a 20-percent increase in the wind sheltering coefficient (WSC) and the baseline (calibrated) model.

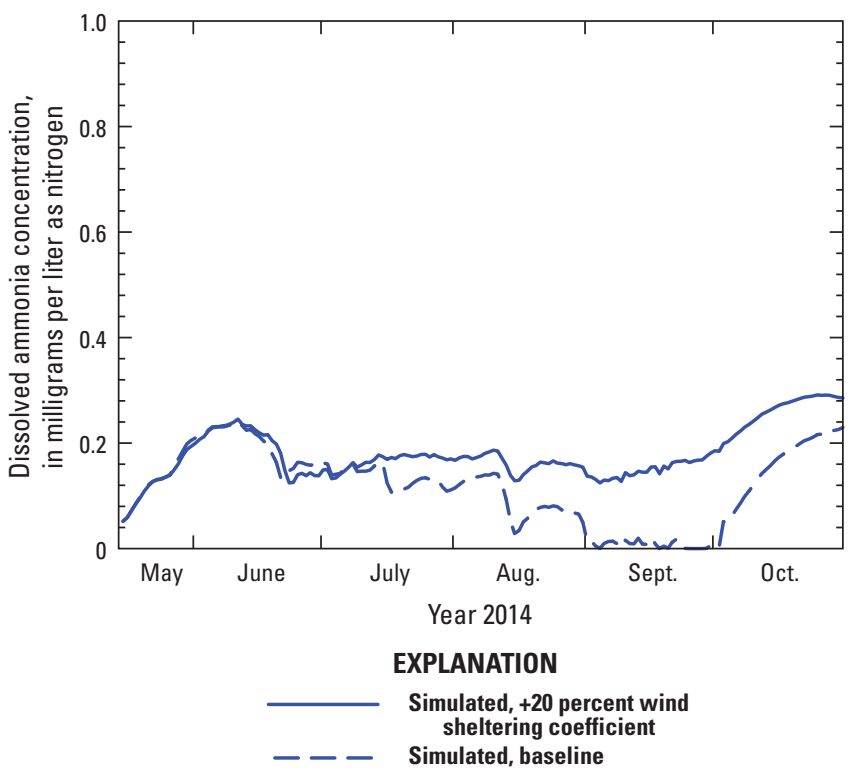

Figure 37. Simulated dissolved ammonia concentrations at 2 meters below the water surface in model segment 7 containing the Madison Lake southwest deep point near Madison Lake, Minnesota, May 15 to November 1, 2014, with a 20-percent increase in the wind sheltering coefficient and the baseline (calibrated) model.

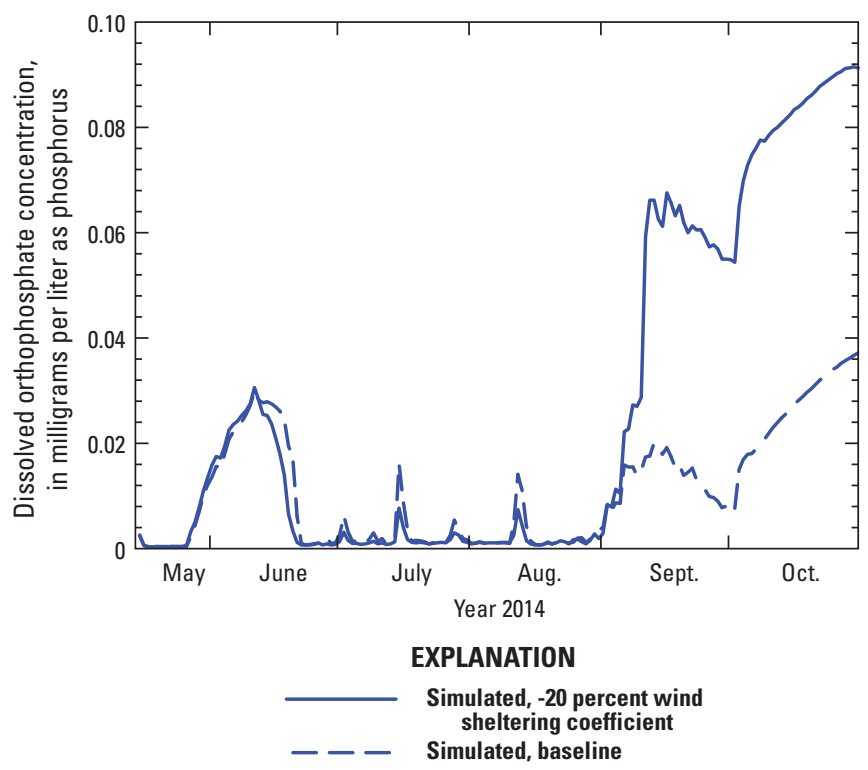

Figure 38. Simulated dissolved orthophosphate concentrations at 2 meters below the water surface in model segment 7 containing the Madison Lake southwest deep point near Madison Lake, Minnesota, May 15 to November 1, 2014, with a 20-percent decrease in the wind sheltering coefficient and the baseline (calibrated) model. 
nitrite were affected by increases in the WSC, inflow nitrogen, and the extinction coefficient (table 7), whereas a decrease in the extinction coefficient affected dissolved ammonia more than an increase. An increase in the WSC caused more flagellates growth later in the summer into September and October (fig. 40), causing a decrease in the available dissolved ammonia (fig. 41) and dissolved nitrate plus nitrite (not shown). The slightly cooler temperatures were more favorable to flagellate growth than blue-green algae. A decrease in WSC, which caused the aforementioned blue-green algal bloom (fig. 39), led to less nutrient uptake because blue-green algae require less nitrogen from the water column. As with Madison Lake, inflow nitrogen increases and decreases led directly to comparable increases or decreases in the dissolved ammonia and dissolved nitrate plus nitrite pools. Changes in SOD, either positive or negative, led to mixed changes for dissolved ammonia and dissolved nitrate plus nitrite, but to a smaller degree than Madison Lake. An increase in the extinction coefficient caused more blue-green algae growth, given its greater light saturation constant for Pearl Lake in comparison to Madison Lake, so less ammonia was required for nutrient uptake (although dissolved nitrate plus nitrite concentrations did decrease by more than 10 percent).
Similar to Madison Lake, dissolved orthophosphate and total phosphorus tracked together in terms of the effects of the different sensitivity parameters for Pearl Lake. Two sensitive parameters, more sensitive than Madison Lake, were the changes in the sediment release rate of phosphorus and the changes in the inflow phosphorus of Pearl Lake. Both pools increased with a 20-percent increase in either of these two parameters, and both pools decreased with a 20-percent decrease. Similar to Madison Lake, dissolved orthophosphate and total phosphorus in Pearl Lake were more sensitive to WSC, SOD, and the extinction coefficients than other parameters. The WSC increase caused more phosphorus burial as additional DO mixing happened throughout the year; a decrease in WSC, which caused the aforementioned bluegreen algal bloom (fig. 39), led to substantially more anoxia and therefore an increase in SOD release of phosphorus. With SOD increases, more phosphorus was released into the water column and vice versa for SOD decreases. Finally, orthophosphate was affected by extinction coefficient increases because less algal growth led to more orthophosphate in the water column.
Figure 39. Simulated algal group distributions (diatoms, green algae, blue-green algae, and flagellates) for the 2-meter depth at Pearl Lake Deep Point near Marty, Minnesota, May 14 to November 13, 2014, with a 20-percent decrease in the wind sheltering coefficient (WSC) and the baseline (calibrated) model.

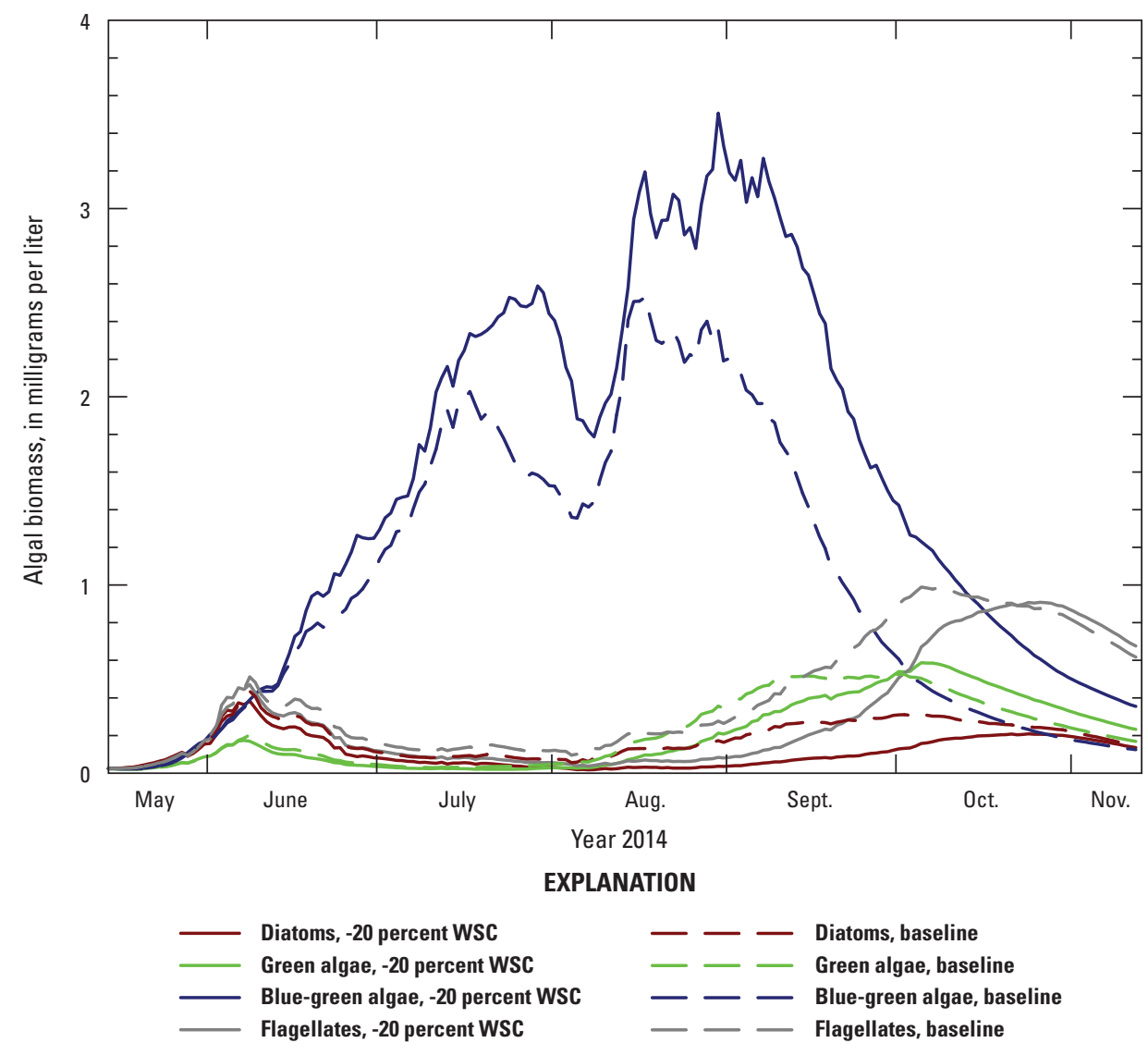




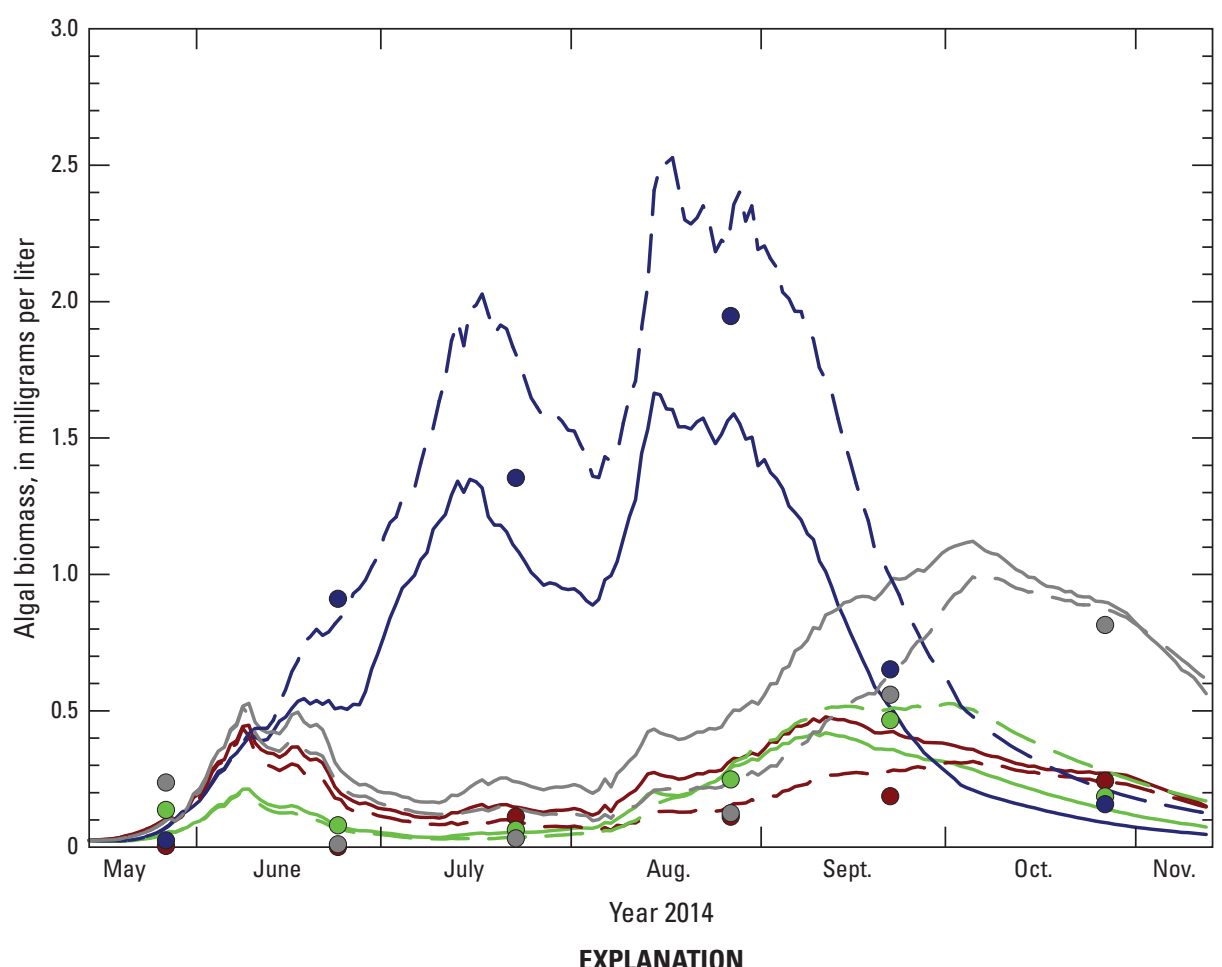

EXPLANATION
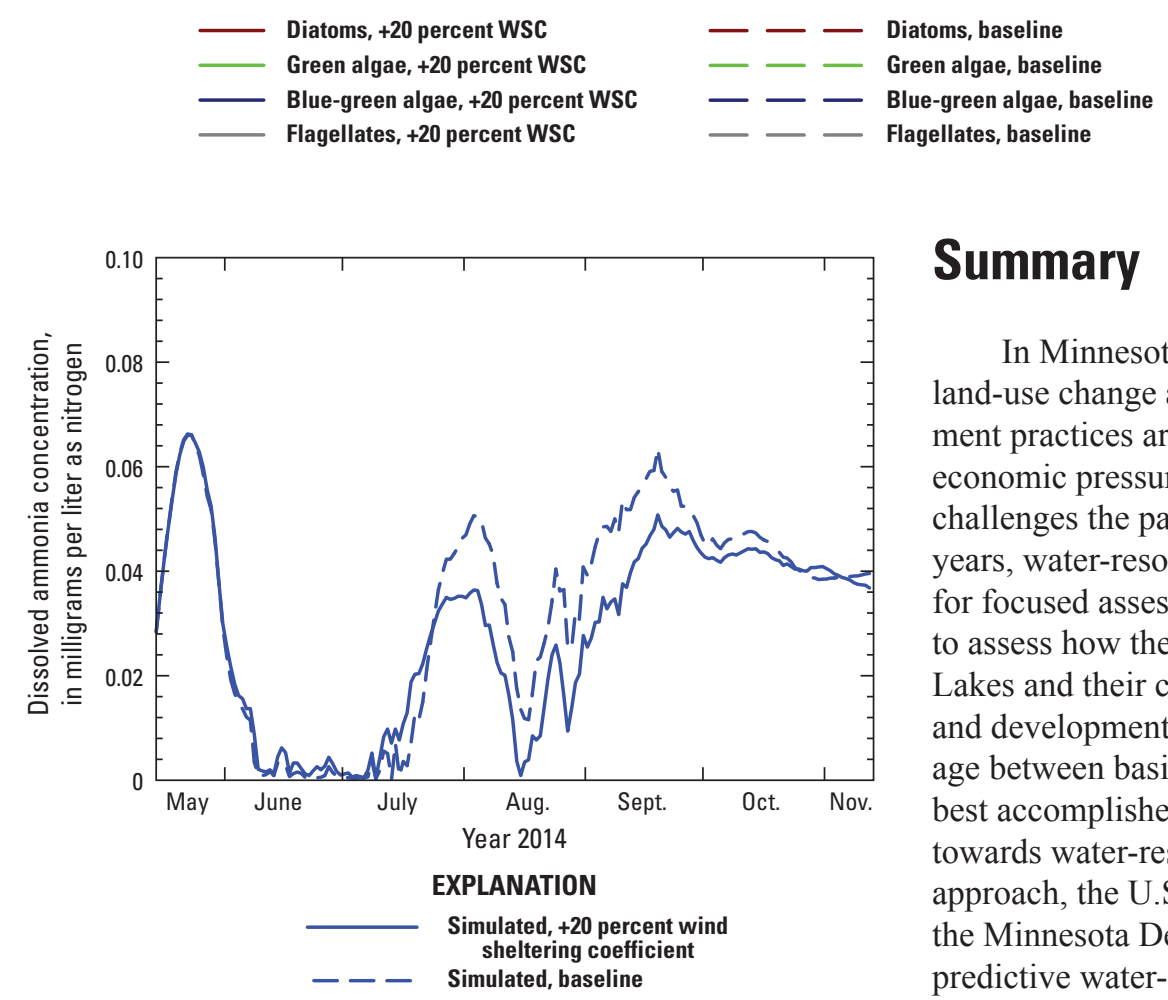

Figure 41. Simulated ammonia concentrations at 2 meters below the water surface in model segment 4 containing the Pearl Lake Deep Point near Marty, Minnesota, May 14 to November 13, 2014, with a 20-percent increase in the wind sheltering coefficient and the baseline (calibrated) model.

\section{Summary}

Figure 40. Simulated algal group distributions (diatoms, green algae, blue-green algae, and flagellates) for the 2-meter depth at Pearl Lake Deep Point near Marty, Minnesota, May 14 to November 13, 2014, with a 20-percent increase in the wind sheltering coefficient (WSC) and the baseline (calibrated) model.

In Minnesota, lakes are facing substantial risks from land-use change and climate change. Although better management practices are being used on agricultural land, increased economic pressure towards high intensity row-crop agriculture challenges the paradigm of improving water quality. In recent years, water-resource scientists have been making the case for focused assessments and monitoring of "sentinel" systems to assess how these stressors affect lakes over the long term. Lakes and their contributing drainage basins are complex, and development of a mechanistic understanding of the linkage between basin-based stressors and lake metabolism is best accomplished by taking a long-term, adaptive approach towards water-resource management. Following the "sentinel" approach, the U.S. Geological Survey, in cooperation with the Minnesota Department of Natural Resources, developed predictive water-quality models for two agricultural land-use dominated lakes in Minnesota. The models were developed to assess algal community dynamics, water quality, and fish habitat suitability of these two lakes under recent (2014) meteorological conditions. The two selected lakes-Pearl Lake and Madison Lake - have abundant cool-water and warm-water fish communities but are threatened with frequent summer blue-green algal blooms that can potentially degrade fish habitat. 
Sources and sinks are largely the same for both lakes. Madison Lake and Pearl Lake have fairly small flows from two different inflows and seem to have considerably large groundwater sources relative to surface inflows. Agricultural land use is the dominant land use for approximately 50 percent of the drainage basin for both lakes. Important distinctions between the two agricultural lakes are the ratio of the drainage basin to lake area, which is 24:1 for Pearl Lake but only 4:1 for Madison Lake. Also, the forest land-use percentage is different between the two different lakes: the Pearl Lake drainage basin has a forest land cover of 15 percent, whereas the Madison Lake drainage basin has a forest cover of 2 percent. Lake residence time is 1-2 years for Pearl Lake and 3-4 years for Madison Lake.

Hydrodynamics and water-quality characteristics were simulated using the CE-QUAL-W2 model, which is a carbonbased, laterally averaged, two-dimensional water-quality model. The CE-QUAL-W2 lake models address the interaction between nutrient cycling, primary production, and trophic dynamics to predict responses in the distribution of temperature and oxygen. The Madison Lake and Pearl Lake models were calibrated using data collected from May through November 2014, including at least one deep location per lake with vertical profiles of water temperature and dissolved oxygen concentration.

The CE-QUAL-W2 model successfully predicted water temperature on the basis of the two metrics of mean absolute error and root mean square error. One of the main calibration tools for CE-QUAL-W2 model development was the vertical profile temperature data. For Madison Lake, the mean absolute error and root mean square error were 0.53 and 0.68 degree Celsius, respectively, for the vertical profile comparisons. Simulated water temperatures were also matched to continuous profile data collected by thermistors at nine fixed depths; eight of the nine depths had mean absolute errors and root mean square errors of $<0.90$ and $<1.10$ degrees Celsius, respectively. For Pearl Lake, the mean absolute error and root mean square error were 0.71 and 0.95 degree Celsius, respectively, for the vertical profile comparisons. Altogether, simulated Madison Lake water temperatures tracked measured water temperatures throughout the water column; for Pearl Lake, simulated water temperature compared better to measured water temperature in the upper mixed layer than in the deeper mixed layer.

In addition to water temperature, the CE-QUAL-W2 model successfully predicted dissolved oxygen concentration based on the same two metrics of mean absolute error and root mean square error. Along with temperature, dissolved oxygen is a key metric to illustrate the accuracy of the model's calibration. For Madison Lake, the mean absolute error and root mean square error were 0.68 milligram per liter and 1.15 milligrams per liter, respectively, for the vertical profile comparisons. Simulated vertical profiles of dissolved oxygen concentration generally matched the largest change in measured dissolved oxygen concentration, including the approximate depth, slope, and timing of large shifts. For Pearl Lake, the mean absolute error and root mean square error were 1.17 and
1.98 milligrams per liter, respectively, for the vertical profile comparisons. Pearl Lake had a total of six profiles, with the first two causing the larger errors; the mean absolute error and root mean square error for the last four profiles were 0.28 and 0.38 milligram per liter, respectively. Overall, dissolved oxygen was more sensitive than water temperature to alterations in the wind sheltering and extinction coefficients; additionally, sediment oxygen demand caused predictable changes for both lake models, with increases in sediment oxygen demand causing negative deviations in the deeper mixed layer and hypolimnion dissolved oxygen concentrations.

Algal dynamics were captured by four general groups: (1) bacillariophyta/crysophyta (diatoms), (2) chlorophyta (green algae), (3) cyanophyta (blue-green algae), and (4) haptophyta/cryptophyta (flagellates). Generally, both lake models successfully simulated algal growth dynamics throughout the year, in particular the prediction of persistent summer blue-green algae blooms in both lakes, early season diatoms in Madison Lake, and late season green algae and flagellate blooms in Pearl Lake.

For Madison Lake, the large nutrient concentrations, particularly nitrate, were tied back to basin processes. Large nitrate loads from the two inflow sites and the distributed tributary flow (mainly groundwater) were the initial sources of nitrate. Once in the lake, combined with consistent delivery of other nutrients such as phosphorus, algal growth and the recycling of nutrients proceeded. As the algae and macrophytes died, decomposition liberated ammonia and other nutrients, leading to a feedback loop. Also, as the decaying organic matter sank deeper into the lake, the deeper mixed layer and the hypolimnion became increasingly hypoxic. This increased hypoxia caused the release of sediment-bound phosphorus, which would initialize more algal growth. Between the external nutrient loading, internal nutrient loading from sediment release of phosphorus, and the organic matter decomposition of the algal and macrophyte biomass, even more algal and macrophyte growth was initiated. This recycling feedback between active growth and decomposition caused the series of algal blooms and the greater nutrient concentrations. Although dissolved ammonia, dissolved nitrate plus nitrite, and total Kjeldahl nitrogen concentrations generally decreased from the beginning of the simulation period to the end, total phosphorus in the hypolimnion continued to increase throughout most of the simulation period. The total phosphorus concentrations in the lake only decreased once the lake overturn caused the phosphorus to become readsorbed and sink to the bottom of the lake, albeit at concentrations of 130 micrograms per liter. At the total phosphorus peak, concentrations reached more than 1,100 micrograms per liter, or more than 1 milligram per liter. Pearl Lake, in comparison to Madison Lake, did not have nearly as large nutrient concentrations. Although external loading did provide nutrients to sustain greater algal growth and blue-green algae blooms, the difference in basin characteristics between the two lakes was likely a driver for lower nutrient concentrations. 
Boundary factors, such as topography and shoreline tree cover, can have a substantial effect on wind mixing. Wind effects from these boundary factors were indirectly augmented through the wind sheltering coefficient. The assigned wind sheltering coefficient was determined to be a sensitive parameter that affected the amount of mixing in the vertical dimension and thereby the depth of the thermocline and dissolved oxygen chemocline over time. Sensitivity analyses were also completed to understand lake response effects through the usage of controlled departures on certain calibrated model parameters and input nutrient loads. These sensitivity analyses operated as land-use change scenarios because alterations in agricultural practices, for example, could potentially increase or decrease nutrient loads.

Available lake habitat suitable for cool-water and warm-water fish assemblages was evaluated for total volume of good-growth habitat, optimal growth habitat, and lethal oxythermal habitat. Criteria were based on thermal constraints and minimum dissolved oxygen thresholds. Overall, the fish habitat volume in general contained a large proportion of good-growth habitat and sustained period of optimal growth habitat in the summer, without any periods of lethal oxythermal habitat.

\section{References Cited}

American Water Works Association, American Public Works Association, and Water Environment Federation, 1997a, 4500-P phosphorus, in Rice, E.W., Baird, R.B., Eaton, A.D., and Clesceri, L.S., eds., Standard methods for the examination of water and wastewater: New York, American Water Works Association, American Public Works Association, and Water Environment Federation, p. 4-108-4-117.

American Water Works Association, American Public Works Association, and Water Environment Federation, 1997b, 10200-H chlorophyll, in Rice, E.W., Baird, R.B., Eaton, A.D., and Clesceri, L.S., eds., Standard methods for the examination of water and wastewater: New York, American Water Works Association, American Public Works Association, and Water Environment Federation, p. 10-18-10-25.

American Water Works Association, American Public Works Association, and Water Environment Federation, 1997c, SM 2540C-Total dissolved solids dried at $180^{\circ} \mathrm{C}$, in Rice, E.W., Baird, R.B., Eaton, A.D., and Clesceri, L.S., eds., Standard methods for the examination of water and wastewater: New York, American Water Works Association, American Public Works Association, and Water Environment Federation, p. 2-57.
American Water Works Association, American Public Works Association, and Water Environment Federation, 1997d, 4500- $\mathrm{SiO}_{2}$ C. molybdosilicate method, in Rice, E.W., Baird, R.B., Eaton, A.D., and Clesceri, L.S., eds., Standard methods for the examination of water and wastewater: New York, American Water Works Association, American Public Works Association, and Water Environment Federation, p. 4-156-4-158.

Anderson, P., and Martin, I., 2015, Standard operating procedures (SOP) — Lake water quality sampling: Minnesota Pollution Control Agency, 17 p.

Anderson, P., Heiskary, S., Diedrich, P., Ohmann, T., Shroyer, S., and Valley, R., 2012, Sentinel lake assessment reportPearl Lake (73-0037), Stearns County, Minnesota: accessed May 11, 2016, at https://www.pca.state.mn.us/sites/default/ files/wq-2slice-73-0037.pdf.

Bales, J.D., and Robbins, J.C., 1999, A dynamic water-quality modeling framework for the Neuse River Estuary, North Carolina: U.S. Geological Survey Water-Resources Investigations Report 99-4017, 42 p. [Also available at http://pubs. usgs.gov/wri/1999/4017/report.pdf.]

Bennett, E.M., Carpenter, S.R., and Caraco, N.F., 2001, Human impact on erodable phosphorus and eutrophication-A global perspective: BioScience, v. 51, no. 3, p. 227-234.

Buchanan, T.J., and Somers, W.P., 1969, Discharge measurements at gaging stations: U.S. Geological Survey Techniques of Water-Resources Investigations, book 3, chap. A8, 71 p. [Also available at http://pubs.usgs.gov/twri/twri3a8/.]

Carlson, R.E., 1977, A trophic state index for lakes: Limnology and Oceanography, v. 22, no. 2, p. 361-369. [Also available at http://doi.org/10.4319/lo.1977.22.2.0361.]

Cole, T.M., and Wells, S.A., 2015, CE-QUAL-W2-A two-dimensional, laterally averaged, hydrodynamic and water quality model, version 4.0: Portland State University Report, 847 p.

Cross, T.K., and Summerfelt, R.C., 1987, Oxygen demand of lakes - Sediment and water column BOD: Lake and Reservoir Management, v. 3, no. 1, p. 109-116. [Also available at http://doi.org/10.1080/07438148709354766.]

Daniel, T.C., Sharpley, A.N., and Lemunyon, J.L., 1998, Agricultural phosphorus and eutrophication-A symposium overview: Journal of Environmental Quality, v. 27, no. 2, p. 251-257. [Also available at http://doi.org/10.2134/jeq199 8.00472425002700020002x.] 
De Stasio, B.T., Jr., Hill, D.K., Kleinhans, J.M., Nibbelink, N.P., and Magnuson, J., 1996, Potential effects of global climate change on small north-temperate lakes-Physics, fish, and plankton: Limnology and Oceanography, v. 41, no. 5, p. 1136-1149. [Also available at http://dx.doi.org/10.4319/ lo.1996.41.5.1136.]

Drake, M.T., and Pereira, D.L., 2002, Development of a fish-based index of biotic integrity for small inland lakes in central Minnesota: North American Journal of Fisheries Management, v. 22, no. 4, p. 1105-1123. [Also available at http://dx.doi.org/10.1577/1548-8675(2002)022\%3c1105:D OAFBI\%3e2.0.CO;2.]

Dumanski, J., Peiretti, R., Benetis, J., McGarry, D., and Pieri, C., 2006, The paradigm of conservation agriculture: Proceedings of World Association of Soil and Water Conservation, Paper No. P1-7, p. 58-64.

Eaton, J.G., McCormick, J.H., Goodno, B.E., O’Brien, D.G., Stefany, H.G., Hondzo, M., and Scheller, R.M., 1995, A field information-based system for estimating fish temperature tolerances: Fisheries, v. 20, no. 4, p. 10-18.

[Also available at http://dx.doi.org/10.1577/

1548-8446(1995)020<0010:AFISFE $>2.0 . C O ; 2$.

Fang, X., Alam, S.R., Jiang, L., Jacobson, P., Pereira, D., and Stefan, H.G., 2010, Simulations of cisco fish habitat in Minnesota lakes under future climate scenarios: St. Anthony Falls Laboratory No. 547, 256 p.

Fang, Xing, Jiang, Liping, Jacobson, P.C., Stefan, H.G., Alam, S.R., and Pereira, D.L., 2012, Identifying cisco refuge lakes in Minnesota under future climate scenarios: Transactions of the American Fisheries Society, v. 141, no. 6, p. 1608-1621. [Also available at http://dx.doi.org/ 10.1080/00028487.2012.713888.]

Fang, X., Stefan, H.G., and Alam, S.R., 1999, Simulation and validation of fish thermal DO habitat in north-central US lakes under different climate scenarios: Ecological Modelling, v. 118, no. 2-3, p. 167-191. [Also available at http://dx.doi.org/10.1016/S0304-3800(99)00018-6.]

Flowers, J.D., Hauck, L.M., and Kiesling, R.L., 2001, USDA Lake Waco-Bosque River Initiative-Water quality modeling of Lake Waco using CE-QUAL-W2 for assessment of phosphorus control strategies: Texas Institute for Applied Environmental Research TR0114, 73 p.

Fraterrigo, J.M., and Downing, J.A., 2008, The influence of land use on lake nutrients varies with watershed transport capacity: Ecosystems, v. 11, no. 7, p. 1021-1034. [Also available at http://doi.org/10.1007/s10021-008-9176-6.]
Galloway, J.M., and Green, W.R., 2006, Application of a twodimensional reservoir water-quality model of Beaver Lake, Arkansas, for the evaluation of simulated changes in input water quality, 2001-2003: U.S. Geological Survey Scientific Investigations Report 2006-5302, 31 p. [Also available at http://pubs.usgs.gov/sir/2006/5302/.]

Galloway, J.M., Ortiz, R.F., Bales, J.D., and Mau, D.P., 2008, Simulation of hydrodynamics and water quality in Pueblo Reservoir, southeastern Colorado, for 1985 through 1987 and 1999 through 2002: U.S. Geological Survey Scientific Investigations Report 2008-5056, 56 p. [Also available at http://pubs.usgs.gov/sir/2008/5056/.]

Green, W.R., Galloway, J.M., Richards, J.M., and Wesolowski, E.A., 2003, Simulation of hydrodynamics, temperature, and dissolved oxygen in Table Rock Lake, Missouri, 19961997: U.S. Geological Survey Water-Resources Investigations Report 2003-4237, 35 p. [Also available at https:// pubs.er.usgs.gov/publication/wri034237.]

Harding, J.S., Young, R.G., Hayes, J.W., Shearer, K.A., and Stark, J.D., 1999, Changes in agricultural intensity and river health along a river continuum: Freshwater Biology, v. 42, no. 2, p. 345-357. [Also available at http://doi.org/10.1046/ j.1365-2427.1999.444470.x.]

Jacobson, P.C., Jones, T.S., Rivers, Pat, and Pereira, D.L., 2008 , Field estimation of a lethal oxythermal niche boundary for adult ciscoes in Minnesota lakes: Transactions of the American Fisheries Society, v. 137, no. 5, p. 1464-1474. [Also available at http://dx.doi.org/10.1577/T07-148.1.]

James, W.F., Sorge, P.W., and Garrison, P.J., 2015, Managing internal phosphorus loading and vertical entrainment in a weakly stratified eutrophic lake: Lake and Reservoir Management, v. 31, no. 4, p. 292-305. [Also available at http://doi.org/10.1080/10402381.2015.1079755.]

Jassby, A.D., 1998, Interannual variability at three inland water sites-Implications for sentinel ecosystems: Ecological Applications, v. 8, no. 2, p. 277-287. [Also available at http://dx.doi.org/10.1890/1051-0761(1998)008[0277:IVATI $\mathrm{W}] 2.0 . \mathrm{CO} ; 2$.

Jiang, L., Fang, X., Stefan, H.G., Jacobson, P.C., and Pereira, D.L., 2012, Oxythermal habitat parameters and identifying cisco refuge lakes in Minnesota under future climate scenarios using variable benchmark periods: Ecological Modelling, v. 232, p. 14-27. [Also available at http://dx.doi.org/10.1016/j.ecolmodel.2012.02.014.]

Lerman, A., 1974, Eutrophication and water quality of lakesControl by water residence time and transport to sediments: Hydrological Sciences Bulletin, v. 19, no. 1, p. 25-34. [Also available at http://dx.doi.org/10.1080/02626667409493867.] 
Lindenberg, M.K., Hoilman, Gene, and Wood, T.M., 2008, Water quality conditions in Upper Klamath and Agency Lakes, Oregon, 2006: U.S. Geological Survey Scientific Investigations Report 2008-5201, 66 p. [Also available at http://pubs.usgs.gov/sir/2008/5201/.]

Lindon, M., and Heiskary, S.A., 2007, Microcystin levels in eutrophic south central Minnesota lakes: Minnesota Lake Water Quality Assessment Series, 53 p. [Also available at https://www.pca.state.mn.us/sites/default/files/ wq-lar3-11.pdf.]

Lindon, M., Valley, R., and Mackenthun, S., 2010, Sentinel lake assessment report-Madison Lake (07-0044), Blue Earth County, Minnesota: accessed May 11, 2016, at https://www.pca.state.mn.us/sites/default/files/ wq-2slice07-0044.pdf.

Magner, J.A., and Brooks, K.N., 2008, Integrating sentinel watershed-systems into the monitoring and assessment of Minnesota's (USA) waters quality: Environmental Monitoring and Assessment, v. 138, no. 1, p. 149-158. [Also available at http:/dx.doi.org/10.1007/s10661-007-9752-9.]

Magnuson, J.J., Benson, B.J., and Kratz, T.K., 1990, Temporal coherence in the limnology of a suite of lakes in Wisconsin, U.S.A.: Freshwater Biology, v. 23, no. 1, p. 145-159. [Also available at http://dx.doi.org/10.1111/j.1365-2427.1990. tb00259.x.]

Marañón, Emilio, Holligan, P.M., Varela, M., Mouriño, B., and Bale, A.J., 2000, Basin-scale variability of phytoplankton biomass, production and growth in the Atlantic Ocean: Deep Sea Research Part I, Oceanographic Research Papers, v. 47 , no. 5 , p. $825-857$. [Also available at http://dx.doi.org/10.1016/S0967-0637(99)00087-4.]

Marsden, M.W., 1989, Lake restoration by reducing external phosphorus loading - The influence of sediment phosphorus release: Freshwater Biology, v. 21, no. 2, p. 139-162. [Also available at http://dx.doi.org/10.1111/j.1365-2427.1989. tb01355.x.]

McDonald, T.L., 2003, Review of environmental monitoring methods-Survey designs: Environmental Monitoring and Assessment, v. 85, no. 3, p. 277-292. [Also available at http://dx.doi.org/10.1023/A:1023954311636.]

Meyer, G.N., Knaeble, A.R., and Tipping, R.G., 1995, Quaternary stratigraphy - Stearns County: University of Minnesota, County Atlas Series, Atlas C-10, Part A, accessed May 11, 2016, at http://conservancy.umn.edu/bitstream/ handle/11299/58515/plate4_quatstrat_150 percent5b1 percent $5 \mathrm{~d}$.pdf? sequence $=6 \&$ is Allowed $=\mathrm{y}$.

Minnesota Department of Agriculture, 2012, The agricultural BMP handbook for Minnesota: Minnesota Department of Agriculture, accessed June 29, 2017, at http://www.eorinc. com/documents/AG-BMPHandbookforMN_09_2012.pdf.
Minnesota Department of Health, 2016, Environmental laboratory sampling and analysis guide: accessed May 11, 2016, at http://www.health.state.mn.us/divs/phl/environmental/ handbook.pdf.

Minnesota Department of Natural Resources, 2010, Sustaining lakes in a changing environment-SLICE: accessed May 11, 2016, at http://files.dnr.state.mn.us/fish_wildlife/ fisheries/slice/rm.pdf.

Minnesota Department of Natural Resources, 2016a, Lake water level report-Madison Lake: accessed May 11, 2016, at http://www.dnr.state.mn.us/lakefind/showlevel. html?downum $=07004400$.

Minnesota Department of Natural Resources, 2016b, Lake water level report-Pearl Lake: accessed May 11, 2016, at http://www.dnr.state.mn.us/lakefind/showlevel. html?downum=73003700.

Minnesota Department of Natural Resources, 2016c, Fisheries lake survey-Madison Lake: accessed May 11, 2016, at http://www.dnr.state.mn.us/lakefind/ showreport.html?downum $=07004400$.

Minnesota Department of Natural Resources, 2016d, Fisheries lake survey-Pearl Lake: accessed May 11, 2016, at http://www.dnr.state.mn.us/lakefind/ showreport.html?downum $=73003700$.

Minnesota Department of Natural Resources, 2016e, LakeFinder: accessed May 11, 2016, at http://www.dnr.state. mn.us/lakefind/index.html.

Minnesota Geospatial Information Office, 2016a, Lake bathymetric outlines, contours, vegetation, and DEM: accessed May 11, 2016, at https://gisdata.mn.gov/dataset/ water-lake-bathymetry.

Minnesota Geospatial Information Office, 2016b, LiDAR elevation data for Minnesota: accessed May 11, 2016, at http://www.mngeo.state.mn.us/chouse/elevation/lidar.html.

Molongoski, J.J., and Klug, M.J., 1980, Quantification and characterization of sedimenting particulate organic matter in a shallow hypereutrophic lake: Freshwater Biology, v. 10 , no. 6 , p. 497-506. [Also available at http://dx.doi.org/10.1111/j.1365-2427.1980.tb01224.x.]

Mueller, D.S., Wagner, C.R., Rehmel, M.S., Oberg, K.A., and Francois, R., 2008, Measuring discharge with acoustic doppler current profilers from a moving boat: U.S. Geological Survey Techniques and Methods, book 3, chap. A22, 86 p. [Also available at http://pubs.usgs.gov/tm/3a22/.]

National Centers for Environmental Information, 2016a, 1981-2010 station normals of temperature, precipitation, and heating and cooling degree days (Mankato, MN, USA, GHCND: USC00215073): National Oceanic and Atmospheric Administration, $4 \mathrm{p}$. 
National Centers for Environmental Information, 2016b, 1981-2010 station normals of temperature, precipitation, and heating and cooling degree days (St. Cloud, MN, USA, GHCND: USC00217294): National Oceanic and Atmospheric Administration, $4 \mathrm{p}$.

National Climatic Data Center, 2016, Climate data online: accessed May 11, 2016, at https://www.ncdc.noaa.gov/ cdo-web/.

Nestler, J.M., Goodwin, R.A., Cole, T.M., Degan, D., and Dennerline, D., 2002, Simulating movement patterns of blueback herring in a stratified southern impoundment: Transactions of the American Fisheries Society, v. 131, no. 1, p. 55-69. [Also available at http://dx.doi.org/ 10.1577/1548-8659(2002)131<0055:SMPOBH>2.0.CO;2.]

Nolan, B.T., Ruddy, B.C., Hitt, K.J., and Helsel, D.R., 1997, Risk of nitrate in groundwaters of the United States-A national perspective: Environmental Science and Technology, v. 31, no. 8, p. 2229-2236. [Also available at http://doi.org/10.1021/es960818d.]

Paerl, H.W., and Paul, V.J., 2012, Climate change-Links to global expansion of harmful cyanobacteria: Water Research, v. 46 , no. 5, p. 1349-1363. [Also available at http://doi.org/10.1016/j.watres.2011.08.002.]

Peterson, J., and Kwak, T., 1999, Modeling the effects of land use and climate change on riverine smallmouth bass: Ecological Applications, v. 9, no. 4, p. 1391-1404. [Also available at http://dx.doi.org/10.1890/ 1051-0761(1999)009\%5b1391:MTEOLU\%5d2.0.CO;2.]

PhycoTech, 2017, General technical approach (ASA): St. Joseph, Michigan, PhycoTech, Inc., 17 p. [Also available at http://www.phycotech.com/public_html/info\%20pack/ GenTech_10182016.pdf.]

Rantz, S.E., and others, 1982a, Measurement and computation of streamflow-Volume 1. Measurement of stage and discharge: U.S. Geological Survey Water-Supply Paper 2175, v. 1, 313 p. [Also available at http://pubs.usgs.gov/ wsp/wsp2175/.]

Rantz, S.E., and others, 1982b, Measurement and computation of streamflow-Volume 2. Computation of discharge: U.S. Geological Survey Water-Supply Paper 2175, v. 2, 373 p. [Also available from http://pubs.usgs.gov/wsp/ wsp2175/.]

Schilling, K.E., Jha, M.K., Zhang, Y.-K., Gassman, P.W., and Wolter, C.F., 2008, Impact of land use and land cover change on the water balance of a large agricultural watershed-Historical effects and future directions: Water Resources Research, v. 44, no. 7. [Also available at http://doi.org/10.1029/2007WR006644.]
Schindler, D.W., 2006, Recent advances in the understanding and management of eutrophication: Limnology and Oceanography, v. 51, no. 1, p. 356-363. [Also available at http://dx.doi.org/10.4319/1o.2006.51.1_part_2.0356.]

Sharpley, A.N., Smith, S.J., and Naney, J.W., 1987, Environmental impact of agricultural nitrogen and phosphorus use: Journal of Agricultural and Food Chemistry, v. 35, no. 5, p. 812-817. [Also available at http://dx.doi.org/10.1021/ jf00077a043.]

Sigee, D.C., 2005, Freshwater microbiology—Biodiversity and dynamic interactions of microorganisms in the aquatic environment: West Sussex, England, John Wiley and Sons Ltd, $524 \mathrm{p}$.

Smith, E.A., and Kiesling, R.L., 2016, Using predictive modeling to assess lake ecosystem responses to stressor gradients: International Falls, Minnesota, International RainyLake of the Woods Watershed Forum.

Smith, E.A., Kiesling, R.L., Galloway, J.M., and Ziegeweid, J.R., 2014, Water quality and algal community dynamics of three sentinel deepwater lakes in Minnesota utilizing CE-QUAL-W2 models: U.S. Geological Survey Scientific Investigations Report 2014-5066, 73 p. [Also available at http://dx.doi.org/10.3133/sir20145066.]

Soulard, C.E., Acevedo, W., Auch, R.F., Sohl, T.L., Drummond, M.A., Sleeter, B.M., Sorenson, D.G., Kambly, S., Wilson, T.S., Taylor, J.L., Sayler, K.L., Stier, M.P., Barnes, C.A., Methven, S.C., Loveland, T.R., Headley, R., and Brooks, M.S., 2014, Land cover trends dataset, 1973-2000: U.S. Geological Survey Data Series 844, 10 p. [Also available at http://dx.doi.org/10.3133/ds844.]

Stefan, H.G., Hondzo, M., Eaton, J.G., and McCormick, J.H., 1995, Predicted effects of global climate change on fishes in Minnesota lakes: Minneapolis, Minnesota, University of Minnesota Supercomputer Institute Research Report UMSI 95/102, $40 \mathrm{p}$.

Stefan, H.G., Hondzo, M., Fang, X., Eaton, J.G., and McCormick, J.H., 1996, Simulated long term temperature and dissolved oxygen characteristics of lakes in the north-central United States and associated fish habitat limits: Limnology and Oceanography, v. 41, no. 5, p. 1124-1135. [Also available at http://dx.doi.org/10.4319/1o.1996.41.5.1124.]

Sullivan, A.B., and Rounds, S.A., 2004, Modeling hydrodynamics, temperature, and water quality in Henry Hagg Lake, Oregon, 2000-03: U.S. Geological Survey Scientific Investigations Report 2004-5261, 38 p. [Also available at http://pubs.usgs.gov/sir/2004/5261/.] 
Sullivan, A.B., Jager, H.I., and Myers, R., 2003, Modeling white sturgeon movement in a reservoir-The effect of water quality and sturgeon density: Ecological Modelling, v. 167 , no. $1-2$, p. $97-114$. [Also available at http://dx.doi. org/10.1016/S0304-3800(03)00169-8.]

Sullivan, A.B., Rounds, S.A., Deas, M.L., Asbill, J.R., Wellman, R.E., Stewart, M.A., Johnston, M.W., and Sogutlugil, I.E., 2011, Modeling hydrodynamics, water temperature, and water quality in the Klamath River upstream of Keno Dam, Oregon, 2006-09: U.S. Geological Survey Scientific Investigations Report 2011-5105, 82 p. [Also available at http://pubs.usgs.gov/sir/2011/5105/.]

Sullivan, A.B., Rounds, S.A., Sobieszczyk, S., and Bragg, H.M., 2007, Modeling hydrodynamics, water temperature, and suspended sediment in Detroit Lake, Oregon: U.S. Geological Survey Scientific Investigations Report 2007-5008, 40 p. [Also available at http://pubs.usgs.gov/ $\operatorname{sir} / 2007 / 5008 /$.

Tong, S.T.Y., and Chen, W., 2002, Modeling the relationship between land use and surface water quality: Journal of Environmental Management, v. 66, no. 4, p. 377-393. [Also available at http://doi.org/10.1006/jema.2002.0593.]

U.S. Environmental Protection Agency, 1993a, Method 353.2, revision 2.0-Determination of nitrate-nitrite nitrogen by automated colorimetry: Cincinnati, Ohio, U.S. Environmental Protection Agency, 14 p.

U.S. Environmental Protection Agency, 1993b, Method 350.1 — Determination of ammonia nitrogen by semi-automated colorimetry: Cincinnati, Ohio, U.S. Environmental Protection Agency, $12 \mathrm{p}$.

U.S. Environmental Protection Agency, 1993c, Method 351.2, revision 2.0-Determination of total kjeldahl nitrogen by semi-automated colorimetry: Cincinnati, Ohio, U.S. Environmental Protection Agency, $15 \mathrm{p}$.

U.S. Environmental Protection Agency, 1993d, Method 365.1, revision 2.0-Determination phosphorus by semi-automated colorimetry: Cincinnati, Ohio, U.S. Environmental Protection Agency, 15 p.

U.S. Environmental Protection Agency, 2002, Guidelines establishing test procedures for the analysis of pollutants (Part 136, Appendix B. Definition and procedure for the determination of the method detection limit-Revision 1.11): U.S. Code of Federal Regulations, Title 40, revised as of July 1, 2002, p. 635-638.
U.S. Environmental Protection Agency, 2007, Method 200.7Trace elements in water, solids, and biosolids by inductively coupled plasma-atomic emission spectrometry: Cincinnati, Ohio, U.S. Environmental Protection Agency, 68 p.

U.S. Geological Survey, 1999, The quality of our Nation's Waters-Nutrients and pesticides: U.S. Geological Survey Circular 1225, 82 p. [Also available at http://pubs.usgs.gov/ circ/circ1225/pdf/index.html.]

U.S. Geological Survey, 2016a, National Water Information System-Web interface: accessed October 6, 2016, at http:// dx.doi.org/10.5066/F7P55KJN.

U.S. Geological Survey, 2016b, National Elevation Dataset: accessed May 11, 2016, at http://ned.usgs.gov/.

Wetzel, R.G., 2001, Limnology lake and river ecosystems (3d ed.): San Diego, California, Elsevier, 1006 p.

Wilde, F.D., ed., 2006, Field measurements: U.S. Geological Survey Techniques of Water-Resources Investigations, book 9, chap. A6, accessed May 11, 2016, at http://pubs.water.usgs.gov/twri9A/.

Williams, A.E., and Burris, R.H., 1952, Nitrogen fixation by blue-green algae and their nitrogenous composition: American Journal of Botany, v. 39, p. 340-342.

Williamson, C.E., Dodds, W., Kratz, T.K., and Palmer, M.A., 2008, Lakes and streams as sentinels of environmental change in terrestrial and atmospheric processes: Frontiers in Ecology and the Environment, v. 6, no. 5, p. 247-254. [Also available at http://doi.org/10.1890/070140.]

Xu, Hai, Paerl, H.W., Qin, B., Zhu, G., and Gaoa, G., 2010, Nitrogen and phosphorus inputs control phytoplankton growth in eutrophic Lake Taihu, China: Limnology and Oceanography, v. 55, no. 1, p. 420-432. [Also available at http://doi.org/10.4319/lo.2010.55.1.0420.] 

Appendixes 


\section{Appendix 1. Elevation-Streamflow Ratings, Unit Value Streamflows, and Daily Mean Streamflows for Madison Lake Inflow and Outflow Sites}

Elevation-streamflow ratings and daily mean streamflows for gaged Madison Lake inflow and outflow sites for the 2014 model calibration are shown in tables 1-1 through $1-4$. Elevation is shown in water-surface elevation referenced to the North American Vertical Datum of 1988. Streamflow values are shown in cubic feet per second and cubic meters per second. The three sites shown in tables 1-1 through 1-4 are unnamed stream to Madison Lake at CR-48 near Madison Lake, Minn. (U.S. Geological Survey [USGS] station 05320130), unnamed stream between Schoolhouse and Goolsby Lakes southeast of Madison Lake, Minn. (USGS station 05320140), and Madison Lake outlet to Mud Lake south of Madison Lake, Minn. (USGS station 05320170). The first tab (table 1-1) contains the elevation-streamflow ratings for all three Madison Lake sites; the second tab (table 1-2) contains the daily mean streamflow record for unnamed stream to Madison Lake at CR-48 near Madison Lake, Minn. (USGS station 05320130), organized monthly similar to the way daily streamflow values are published in USGS Annual Water Data Reports (http://wdr.water.usgs.gov/); the third tab (table 1-3) contains the daily mean streamflow record for unnamed stream between Schoolhouse and Goolsby Lakes southeast of Madison Lake, Minn. (USGS station 05320140); the fourth tab (table 1-4) contains the daily mean streamflow record for Madison Lake outlet to Mud Lake south of Madison Lake, Minn. (USGS station 05320170).

Table 1-1. Elevation-streamflow ratings for gaged Madison Lake inflow and outflow sites.

[ft; foot; $\mathrm{ft}^{3} / \mathrm{s}$, cubic foot per second; $\mathrm{m}^{3} / \mathrm{s}$, meter per second; ---, not determined]

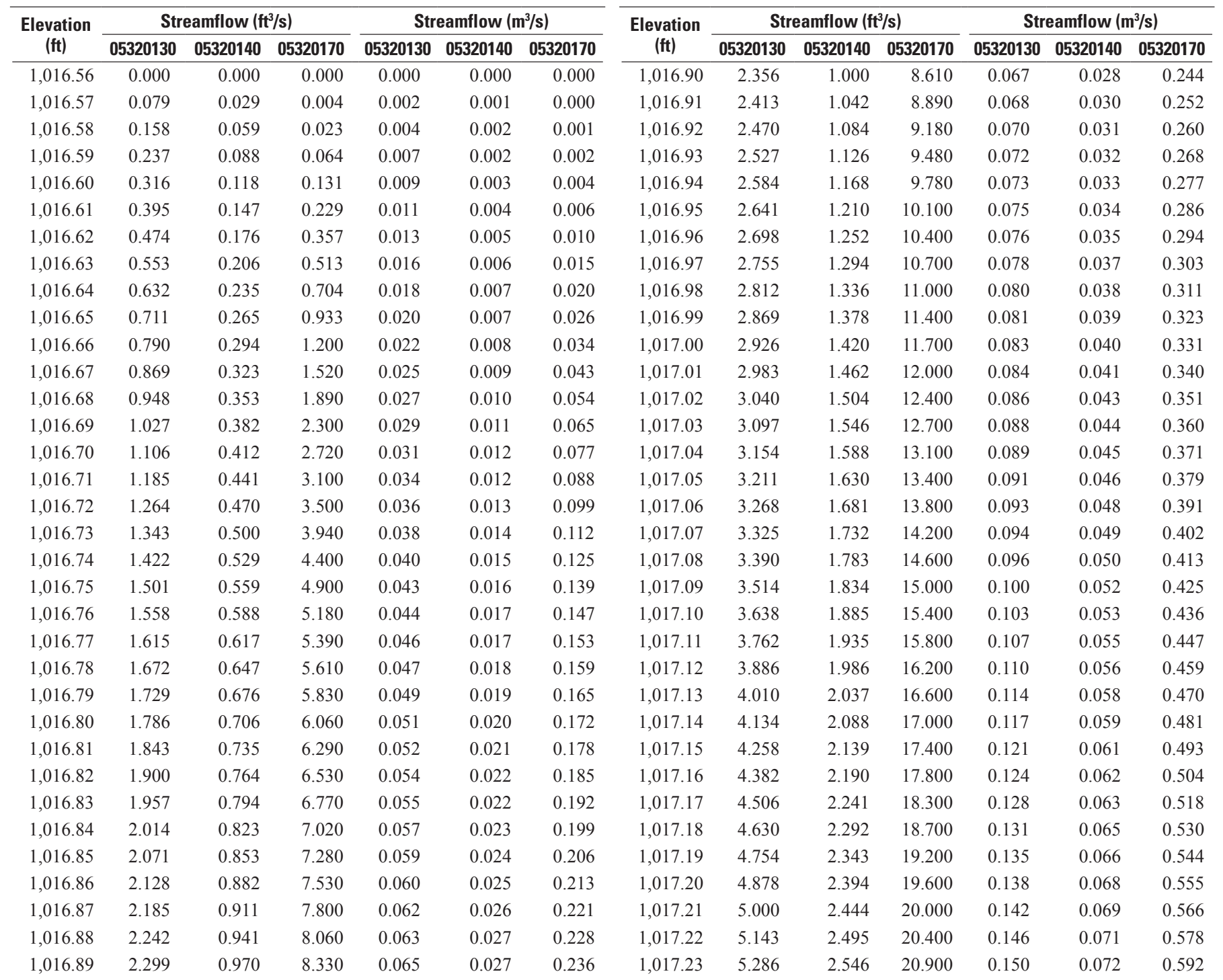


Table 1-1. Elevation-streamflow ratings for gaged Madison Lake inflow and outflow sites.-Continued

[ft; foot; $\mathrm{ft}^{3} / \mathrm{s}$, cubic foot per second; $\mathrm{m}^{3} / \mathrm{s}$, meter per second; ---, not determined]

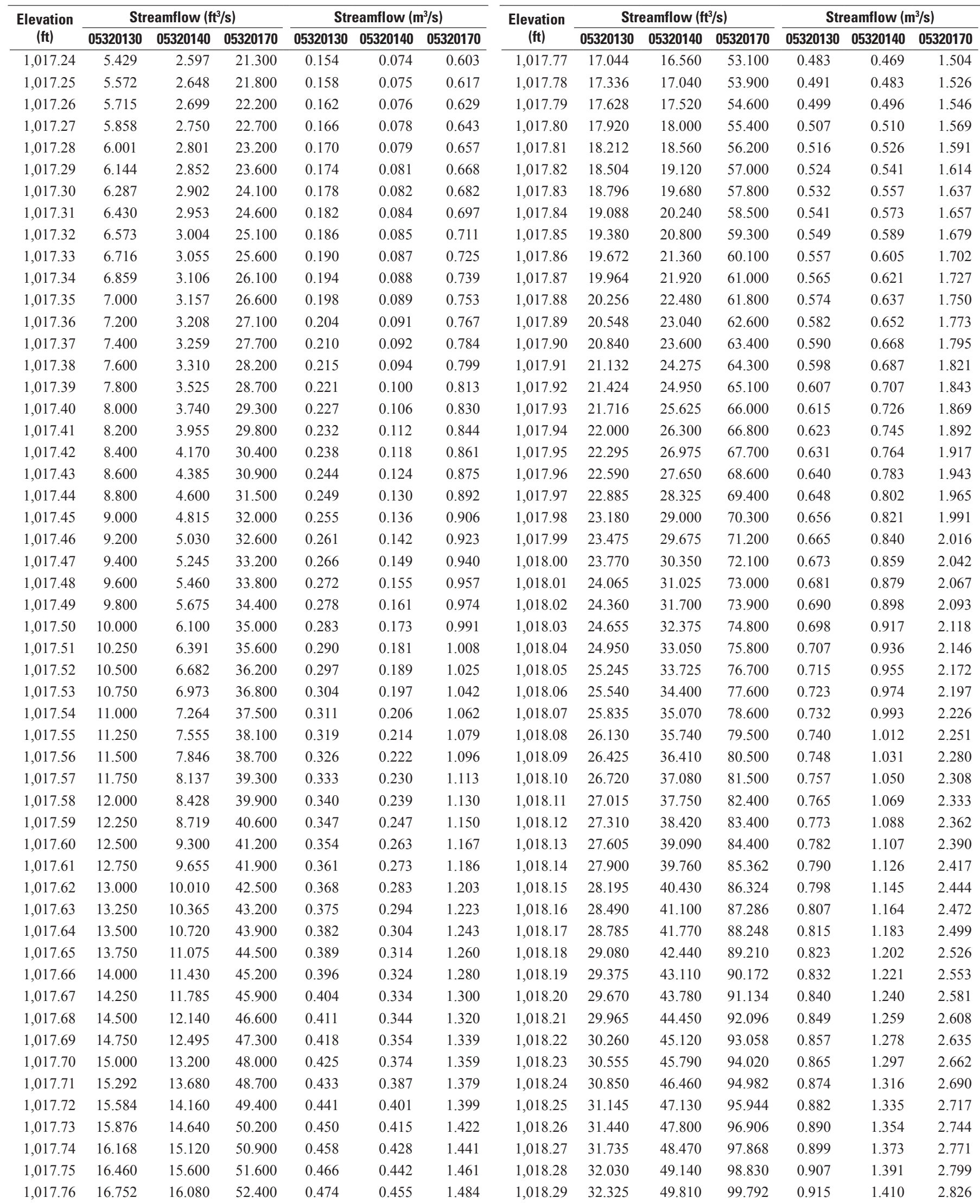


Table 1-1. Elevation-streamflow ratings for gaged Madison Lake inflow and outflow sites.-Continued

[ft; foot; $\mathrm{ft}^{3} / \mathrm{s}$, cubic foot per second; $\mathrm{m}^{3} / \mathrm{s}$, meter per second; ---, not determined]

\begin{tabular}{|c|c|c|c|c|c|c|c|c|c|c|c|c|c|}
\hline \multirow{2}{*}{$\begin{array}{l}\text { Elevation } \\
\text { (ft) }\end{array}$} & \multicolumn{3}{|c|}{ Streamflow $\left(\mathrm{ft}^{3} / \mathrm{s}\right)$} & \multicolumn{3}{|c|}{ Streamflow $\left(\mathrm{m}^{3} / \mathrm{s}\right)$} & \multirow{2}{*}{$\begin{array}{c}\text { Elevation } \\
\text { (ft) }\end{array}$} & \multicolumn{3}{|c|}{ Streamflow $\left(\mathrm{ft}^{3} / \mathrm{s}\right)$} & \multicolumn{3}{|c|}{ Streamflow $\left(\mathrm{m}^{3} / \mathrm{s}\right)$} \\
\hline & 05320130 & 05320140 & 05320170 & 05320130 & 05320140 & 05320170 & & 05320130 & 05320140 & 05320170 & 05320130 & 05320140 & 05320170 \\
\hline $1,018.30$ & 32.620 & 50.480 & 100.754 & 0.924 & 1.429 & 2.853 & $1,018.83$ & 48.255 & 85.990 & --- & 1.366 & 2.435 & --- \\
\hline $1,018.31$ & 32.915 & 51.150 & 101.716 & 0.932 & 1.448 & 2.880 & $1,018.84$ & 48.550 & 86.660 & --- & 1.375 & 2.454 & --- \\
\hline $1,018.32$ & 33.210 & 51.820 & 102.678 & 0.940 & 1.467 & 2.908 & $1,018.85$ & 48.845 & 87.330 & --- & 1.383 & 2.473 & --- \\
\hline $1,018.33$ & 33.505 & 52.490 & 103.640 & 0.949 & 1.486 & 2.935 & $1,018.86$ & 49.140 & 88.000 & --- & 1.391 & 2.492 & --- \\
\hline $1,018.34$ & 33.800 & 53.160 & 104.602 & 0.957 & 1.505 & 2.962 & $1,018.87$ & 49.435 & 88.670 & --- & 1.400 & 2.511 & --- \\
\hline $1,018.35$ & 34.095 & 53.830 & 105.564 & 0.965 & 1.524 & 2.989 & $1,018.88$ & 49.730 & 89.340 & --- & 1.408 & 2.530 & --- \\
\hline $1,018.36$ & 34.390 & 54.500 & 106.526 & 0.974 & 1.543 & 3.016 & $1,018.89$ & 50.025 & 90.010 & --- & 1.417 & 2.549 & --- \\
\hline $1,018.37$ & 34.685 & 55.170 & 107.488 & 0.982 & 1.562 & 3.044 & $1,018.90$ & 50.320 & 90.680 & --- & 1.425 & 2.568 & --- \\
\hline $1,018.38$ & 34.980 & 55.840 & 108.450 & 0.991 & 1.581 & 3.071 & $1,018.91$ & 50.615 & 91.350 & --- & 1.433 & 2.587 & --- \\
\hline $1,018.39$ & 35.275 & 56.510 & 109.412 & 0.999 & 1.600 & 3.098 & $1,018.92$ & 50.910 & 92.020 & --- & 1.442 & 2.606 & --- \\
\hline $1,018.40$ & 35.570 & 57.180 & 110.374 & 1.007 & 1.619 & 3.125 & $1,018.93$ & 51.205 & 92.690 & --- & 1.450 & 2.625 & -- \\
\hline $1,018.41$ & 35.865 & 57.850 & 111.336 & 1.016 & 1.638 & 3.153 & $1,018.94$ & 51.500 & 93.360 & --- & 1.458 & 2.644 & --- \\
\hline $1,018.42$ & 36.160 & 58.520 & 112.298 & 1.024 & 1.657 & 3.180 & $1,018.95$ & 51.795 & 94.030 & --- & 1.467 & 2.663 & --- \\
\hline $1,018.43$ & 36.455 & 59.190 & 113.260 & 1.032 & 1.676 & 3.207 & $1,018.96$ & 52.090 & 94.700 & --- & 1.475 & 2.682 & --- \\
\hline $1,018.44$ & 36.750 & 59.860 & 114.222 & 1.041 & 1.695 & 3.234 & $1,018.97$ & 52.385 & 95.370 & --- & 1.483 & 2.701 & --- \\
\hline $1,018.45$ & 37.045 & 60.530 & 115.184 & 1.049 & 1.714 & 3.262 & $1,018.98$ & 52.680 & 96.000 & --- & 1.492 & 2.718 & --- \\
\hline $1,018.46$ & 37.340 & 61.200 & 116.146 & 1.057 & 1.733 & 3.289 & $1,018.99$ & 52.975 & --- & --- & 1.500 & --- & --- \\
\hline $1,018.47$ & 37.635 & 61.870 & 117.108 & 1.066 & 1.752 & 3.316 & $1,019.00$ & 53.270 & --- & --- & 1.508 & --- & -- \\
\hline $1,018.48$ & 37.930 & 62.540 & 118.070 & 1.074 & 1.771 & 3.343 & $1,019.01$ & 53.565 & --- & --- & 1.517 & --- & --- \\
\hline $1,018.49$ & 38.225 & 63.210 & 119.032 & 1.082 & 1.790 & 3.371 & $1,019.02$ & 53.860 & --- & --- & 1.525 & --- & --- \\
\hline $1,018.50$ & 38.520 & 63.880 & 119.994 & 1.091 & 1.809 & 3.398 & $1,019.03$ & 54.155 & --- & --- & 1.533 & --- & --- \\
\hline $1,018.51$ & 38.815 & 64.550 & 120.956 & 1.099 & 1.828 & 3.425 & $1,019.04$ & 54.450 & --- & --- & 1.542 & --- & --- \\
\hline $1,018.52$ & 39.110 & 65.220 & 121.918 & 1.107 & 1.847 & 3.452 & $1,019.05$ & 54.745 & --- & --- & 1.550 & --- & --- \\
\hline $1,018.53$ & 39.405 & 65.890 & 122.880 & 1.116 & 1.866 & 3.480 & $1,019.06$ & 55.040 & --- & --- & 1.559 & --- & --- \\
\hline $1,018.54$ & 39.700 & 66.560 & 123.842 & 1.124 & 1.885 & 3.507 & $1,019.07$ & 55.335 & --- & --- & 1.567 & --- & --- \\
\hline $1,018.55$ & 39.995 & 67.230 & 124.804 & 1.133 & 1.904 & 3.534 & $1,019.08$ & 55.630 & --- & --- & 1.575 & --- & --- \\
\hline $1,018.56$ & 40.290 & 67.900 & 125.766 & 1.141 & 1.923 & 3.561 & $1,019.09$ & 55.925 & --- & --- & 1.584 & --- & --- \\
\hline $1,018.57$ & 40.585 & 68.570 & 126.728 & 1.149 & 1.942 & 3.589 & $1,019.10$ & 56.220 & --- & --- & 1.592 & --- & --- \\
\hline $1,018.58$ & 40.880 & 69.240 & 127.690 & 1.158 & 1.961 & 3.616 & $1,019.11$ & 56.515 & --- & --- & 1.600 & --- & --- \\
\hline $1,018.59$ & 41.175 & 69.910 & 128.652 & 1.166 & 1.980 & 3.643 & $1,019.12$ & 56.810 & --- & --- & 1.609 & --- & --- \\
\hline $1,018.60$ & 41.470 & 70.580 & 129.614 & 1.174 & 1.999 & 3.670 & $1,019.13$ & 57.105 & --- & --- & 1.617 & --- & --- \\
\hline $1,018.61$ & 41.765 & 71.250 & 130.576 & 1.183 & 2.018 & 3.698 & $1,019.14$ & 57.400 & --- & --- & 1.625 & --- & --- \\
\hline $1,018.62$ & 42.060 & 71.920 & 131.538 & 1.191 & 2.037 & 3.725 & $1,019.15$ & 57.695 & --- & --- & 1.634 & --- & --- \\
\hline $1,018.63$ & 42.355 & 72.590 & 132.500 & 1.199 & 2.056 & 3.752 & $1,019.16$ & 57.990 & --- & --- & 1.642 & --- & --- \\
\hline $1,018.64$ & 42.650 & 73.260 & 133.462 & 1.208 & 2.074 & 3.779 & $1,019.17$ & 58.285 & --- & --- & 1.650 & --- & --- \\
\hline $1,018.65$ & 42.945 & 73.930 & 134.424 & 1.216 & 2.093 & 3.806 & $1,019.18$ & 58.580 & --- & --- & 1.659 & --- & --- \\
\hline $1,018.66$ & 43.240 & 74.600 & 135.386 & 1.224 & 2.112 & 3.834 & $1,019.19$ & 58.875 & --- & --- & 1.667 & --- & --- \\
\hline $1,018.67$ & 43.535 & 75.270 & 136.348 & 1.233 & 2.131 & 3.861 & $1,019.20$ & 59.170 & --- & --- & 1.676 & --- & --- \\
\hline $1,018.68$ & 43.830 & 75.940 & 137.310 & 1.241 & 2.150 & 3.888 & $1,019.21$ & 59.465 & --- & --- & 1.684 & --- & --- \\
\hline $1,018.69$ & 44.125 & 76.610 & 138.272 & 1.249 & 2.169 & 3.915 & $1,019.22$ & 59.760 & --- & --- & 1.692 & --- & --- \\
\hline $1,018.70$ & 44.420 & 77.280 & 139.234 & 1.258 & 2.188 & 3.943 & $1,019.23$ & 60.055 & --- & --- & 1.701 & --- & --- \\
\hline $1,018.71$ & 44.715 & 77.950 & 140.196 & 1.266 & 2.207 & 3.970 & $1,019.24$ & 60.350 & --- & --- & 1.709 & --- & --- \\
\hline $1,018.72$ & 45.010 & 78.620 & 141.158 & 1.275 & 2.226 & 3.997 & $1,019.25$ & 60.645 & --- & --- & 1.717 & --- & --- \\
\hline $1,018.73$ & 45.305 & 79.290 & 142.120 & 1.283 & 2.245 & 4.024 & $1,019.26$ & 60.940 & --- & --- & 1.726 & --- & --- \\
\hline $1,018.74$ & 45.600 & 79.960 & 143.082 & 1.291 & 2.264 & 4.052 & $1,019.27$ & 61.235 & --- & --- & 1.734 & --- & --- \\
\hline $1,018.75$ & 45.895 & 80.630 & 144.044 & 1.300 & 2.283 & 4.079 & $1,019.28$ & 61.530 & --- & --- & 1.742 & --- & --- \\
\hline $1,018.76$ & 46.190 & 81.300 & 145.006 & 1.308 & 2.302 & 4.106 & $1,019.29$ & 61.825 & --- & --- & 1.751 & --- & --- \\
\hline $1,018.77$ & 46.485 & 81.970 & --- & 1.316 & 2.321 & --- & $1,019.30$ & 62.120 & --- & --- & 1.759 & --- & --- \\
\hline $1,018.78$ & 46.780 & 82.640 & --- & 1.325 & 2.340 & --- & $1,019.31$ & 62.415 & --- & --- & 1.767 & --- & --- \\
\hline $1,018.79$ & 47.075 & 83.310 & --- & 1.333 & 2.359 & --- & $1,019.32$ & 62.710 & --- & --- & 1.776 & --- & --- \\
\hline $1,018.80$ & 47.370 & 83.980 & --- & 1.341 & 2.378 & --- & $1,019.33$ & 63.005 & --- & --- & 1.784 & --- & --- \\
\hline $1,018.81$ & 47.665 & 84.650 & --- & 1.350 & 2.397 & --- & $1,019.34$ & 63.300 & --- & --- & 1.792 & --- & --- \\
\hline $1,018.82$ & 47.960 & 85.320 & --- & 1.358 & 2.416 & --- & $1,019.35$ & 63.595 & --- & --- & 1.801 & --- & --- \\
\hline
\end{tabular}


Table 1-1. Elevation-streamflow ratings for gaged Madison Lake inflow and outflow sites.-Continued

[ft; foot; $\mathrm{ft}^{3} / \mathrm{s}$, cubic foot per second; $\mathrm{m}^{3} / \mathrm{s}$, meter per second; ---, not determined]

\begin{tabular}{|c|c|c|c|c|c|c|}
\hline \multirow{2}{*}{$\begin{array}{l}\text { Elevation } \\
\text { (ft) }\end{array}$} & \multicolumn{3}{|c|}{ Streamflow $\left(\mathrm{ft}^{3} / \mathrm{s}\right)$} & \multicolumn{3}{|c|}{ Streamflow $\left(\mathrm{m}^{3} / \mathrm{s}\right)$} \\
\hline & 05320130 & 05320140 & 05320170 & 05320130 & 05320140 & 05320170 \\
\hline $1,019.36$ & 63.890 & --- & --- & 1.809 & --- & --- \\
\hline $1,019.37$ & 64.185 & --- & --- & 1.818 & --- & --- \\
\hline $1,019.38$ & 64.480 & --- & --- & 1.826 & --- & --- \\
\hline $1,019.39$ & 64.775 & --- & --- & 1.834 & --- & --- \\
\hline $1,019.40$ & 65.070 & --- & --- & 1.843 & --- & --- \\
\hline $1,019.41$ & 65.365 & --- & --- & 1.851 & --- & --- \\
\hline $1,019.42$ & 65.660 & --- & --- & 1.859 & --- & -- \\
\hline $1,019.43$ & 65.955 & --- & --- & 1.868 & --- & --- \\
\hline $1,019.44$ & 66.250 & --- & --- & 1.876 & --- & --- \\
\hline $1,019.45$ & 66.545 & --- & --- & 1.884 & --- & --- \\
\hline $1,019.46$ & 66.840 & --- & --- & 1.893 & --- & --- \\
\hline $1,019.47$ & 67.135 & --- & --- & 1.901 & --- & --- \\
\hline $1,019.48$ & 67.430 & --- & --- & 1.909 & --- & --- \\
\hline $1,019.49$ & 67.725 & --- & --- & 1.918 & --- & --- \\
\hline $1,019.50$ & 68.000 & --- & --- & 1.926 & --- & --- \\
\hline
\end{tabular}


Table 1-2. Daily mean streamflows for unnamed stream to Madison Lake at CR-48 near Madison Lake, Minnesota (USGS station 05320130), May-November 2014.

$[---$, not determined]

\begin{tabular}{|c|c|c|c|c|c|c|c|}
\hline \multirow{2}{*}{ Day } & \multicolumn{7}{|c|}{ Daily mean streanflows, in cubic meters per second } \\
\hline & May 2014 & June 2014 & July 2014 & August 2014 & September 2014 & October 2014 & November 2014 \\
\hline 1 & --- & 0.2880 & 0.8678 & 0.0642 & 0.0189 & --- & --- \\
\hline 2 & --- & 0.3347 & 0.7976 & 0.0611 & 0.0164 & --- & --- \\
\hline 3 & --- & 0.3109 & 0.6643 & 0.0588 & 0.0128 & --- & --- \\
\hline 4 & --- & 0.2827 & 0.5930 & 0.0561 & 0.0114 & --- & --- \\
\hline 5 & --- & 0.2667 & 0.5374 & 0.0526 & 0.0059 & --- & --- \\
\hline 6 & --- & 0.2467 & 0.4909 & 0.0487 & 0.0011 & --- & --- \\
\hline 7 & --- & 0.2327 & 0.4426 & 0.0449 & --- & --- & --- \\
\hline 8 & --- & 0.2167 & 0.3930 & 0.0417 & --- & --- & --- \\
\hline 9 & --- & 0.1966 & 0.3421 & 0.0385 & --- & --- & --- \\
\hline 10 & --- & 0.1827 & 0.2960 & 0.0354 & --- & --- & --- \\
\hline 11 & --- & 0.1726 & 0.2705 & 0.0323 & --- & --- & --- \\
\hline 12 & --- & 0.1641 & 0.2555 & 0.0253 & --- & --- & --- \\
\hline 13 & --- & 0.1408 & 0.2409 & 0.0203 & --- & --- & --- \\
\hline 14 & --- & 0.1327 & 0.2168 & 0.0150 & --- & --- & --- \\
\hline 15 & 0.5901 & 0.1839 & 0.1951 & 0.0119 & --- & --- & --- \\
\hline 16 & 0.5587 & 0.2013 & 0.2102 & 0.0087 & --- & --- & --- \\
\hline 17 & 0.5290 & 0.3181 & 0.1881 & 0.0067 & --- & --- & --- \\
\hline 18 & 0.4985 & 0.9070 & 0.1713 & 0.0079 & --- & --- & --- \\
\hline 19 & 0.4656 & 1.3229 & 0.1548 & 0.0046 & --- & --- & --- \\
\hline 20 & 0.4441 & 1.5764 & 0.1398 & 0.0008 & --- & --- & --- \\
\hline 21 & 0.4203 & 1.5385 & 0.1275 & 0.0265 & --- & --- & --- \\
\hline 22 & 0.3917 & 1.4527 & 0.1183 & 0.0302 & --- & --- & --- \\
\hline 23 & 0.3644 & 1.3690 & 0.1042 & 0.0274 & --- & --- & --- \\
\hline 24 & 0.3392 & 1.2886 & 0.0946 & 0.0268 & --- & --- & --- \\
\hline 25 & 0.3128 & 1.2144 & 0.0941 & 0.0237 & --- & --- & --- \\
\hline 26 & 0.2921 & 1.1488 & 0.0912 & 0.0164 & --- & --- & --- \\
\hline 27 & 0.2977 & 1.0833 & 0.0863 & 0.0111 & --- & --- & --- \\
\hline 28 & 0.2803 & 1.0325 & 0.0800 & 0.0075 & --- & --- & --- \\
\hline 29 & 0.2585 & 0.9950 & 0.0756 & 0.0137 & --- & --- & --- \\
\hline 30 & 0.2372 & 0.9289 & 0.0712 & 0.0133 & --- & --- & --- \\
\hline 31 & 0.2294 & --- & 0.0676 & 0.0120 & --- & --- & --- \\
\hline
\end{tabular}


Table 1-3. Daily mean streamflows for unnamed stream between Schoolhouse and Goolsby Lakes southeast of Madison Lake, Minnesota (USGS station 05320140), May-November 2014.

[---, not determined]

\begin{tabular}{|c|c|c|c|c|c|c|c|}
\hline \multirow{2}{*}{ Day } & \multicolumn{7}{|c|}{ Daily mean streanflows, in cubic meters per second } \\
\hline & May 2014 & June 2014 & July 2014 & August 2014 & September 2014 & October 2014 & November 2014 \\
\hline 1 & --- & 0.3046 & 1.6030 & 0.0457 & 0.0240 & 0.0005 & --- \\
\hline 2 & --- & 0.3716 & 1.4468 & 0.0435 & 0.0229 & 0.0048 & --- \\
\hline 3 & --- & 0.3381 & 1.2917 & 0.0424 & 0.0209 & 0.0102 & --- \\
\hline 4 & --- & 0.3130 & 1.1397 & 0.0404 & 0.0206 & 0.0056 & --- \\
\hline 5 & --- & 0.2759 & 1.0067 & 0.0381 & 0.0202 & 0.0014 & --- \\
\hline 6 & --- & 0.2538 & 0.9170 & 0.0353 & 0.0173 & 0.0004 & --- \\
\hline 7 & --- & 0.2391 & 0.8146 & 0.0342 & 0.0147 & 0.0006 & --- \\
\hline 8 & --- & 0.2127 & 0.7192 & 0.0338 & 0.0122 & --- & --- \\
\hline 9 & --- & 0.1856 & 0.5822 & 0.0317 & 0.0117 & --- & --- \\
\hline 10 & --- & 0.1563 & 0.4804 & 0.0298 & 0.0152 & --- & --- \\
\hline 11 & --- & 0.1377 & 0.4203 & 0.0303 & 0.0121 & --- & --- \\
\hline 12 & --- & 0.1322 & 0.3854 & 0.0267 & 0.0101 & --- & --- \\
\hline 13 & --- & 0.0957 & 0.3459 & 0.0243 & 0.0079 & --- & --- \\
\hline 14 & --- & 0.0895 & 0.3113 & 0.0222 & 0.0069 & --- & --- \\
\hline 15 & 0.9277 & 0.1656 & 0.2568 & 0.0204 & 0.0072 & --- & --- \\
\hline 16 & 0.8540 & 0.2148 & 0.1997 & 0.0198 & 0.0055 & --- & --- \\
\hline 17 & 0.7903 & 0.4586 & 0.1456 & 0.0187 & 0.0047 & --- & --- \\
\hline 18 & 0.7031 & 1.6554 & 0.1211 & 0.0193 & 0.0036 & --- & --- \\
\hline 19 & 0.6433 & 2.1885 & 0.0990 & 0.0187 & 0.0013 & --- & --- \\
\hline 20 & 0.6243 & 2.5215 & 0.0899 & 0.0166 & 0.0041 & --- & --- \\
\hline 21 & 0.5903 & 2.5847 & 0.0864 & 0.0272 & 0.0060 & --- & --- \\
\hline 22 & 0.5210 & 2.5794 & 0.0832 & 0.0301 & 0.0032 & --- & --- \\
\hline 23 & 0.4615 & 2.5421 & 0.0784 & 0.0283 & 0.0014 & --- & --- \\
\hline 24 & 0.4033 & 2.4670 & 0.0728 & 0.0266 & 0.0008 & --- & --- \\
\hline 25 & 0.3480 & 2.3551 & 0.0717 & 0.0261 & 0.0008 & --- & --- \\
\hline 26 & 0.3246 & 2.2022 & 0.0696 & 0.0238 & 0.0003 & --- & --- \\
\hline 27 & 0.3427 & 2.0575 & 0.0647 & 0.0215 & --- & --- & --- \\
\hline 28 & 0.3178 & 1.9296 & 0.0608 & 0.0200 & --- & --- & --- \\
\hline 29 & 0.2761 & 1.8486 & 0.0553 & 0.0218 & --- & --- & --- \\
\hline 30 & 0.2305 & 1.7269 & 0.0516 & 0.0225 & --- & --- & --- \\
\hline 31 & 0.2069 & --- & 0.0482 & 0.0205 & --- & --- & --- \\
\hline
\end{tabular}


Table 1-4. Daily mean streamflows for Madison Lake outlet to Mud Lake south of Madison Lake, Minnesota (USGS station 05320170), May-November 2014.

$[---$, not determined $]$

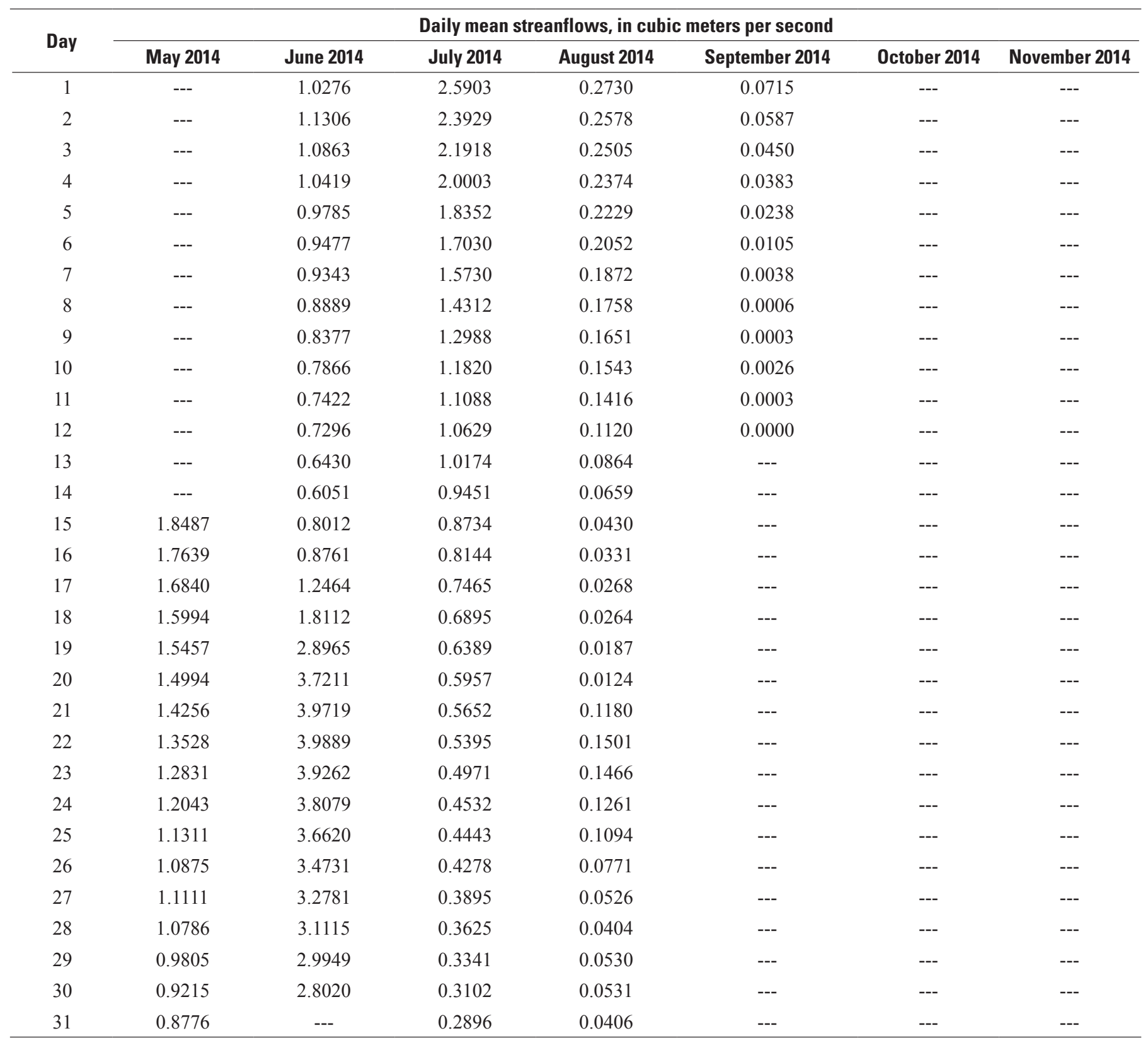




\section{Appendix 2. Relative Counts and Converted Algal Biomass for Madison Lake, Minnesota, and Pearl Lake, Minnesota}

Relative counts and converted algal biomass (in milligrams per liter) for Madison Lake southwest deep point near Madison Lake, Minnesota, and Pearl Lake Deep Point near Marty, Minnesota, for 2014.

Table 2-1. Summary of relative counts and converted algal biomass for Madison Lake and Pearl Lake, May-November 2014. [mg/L, milligram per liter]

\begin{tabular}{|c|c|c|c|c|}
\hline Constituent & Common name in report & Date & Relative count & Converted algal biomass (mg/L) \\
\hline \multicolumn{5}{|c|}{ Madison Lake } \\
\hline \multirow[t]{6}{*}{ Diatoms/crysophyta } & Diatoms & 2014-05-14 & 88 & 3.168 \\
\hline & & 2014-06-18 & 5 & 0.054 \\
\hline & & $2014-07-29$ & 38 & 1.767 \\
\hline & & 2014-08-21 & 5 & 0.369 \\
\hline & & 2014-09-17 & 16 & 1.277 \\
\hline & & 2014-10-21 & 1 & 0.003 \\
\hline \multirow[t]{6}{*}{ Chlorophyta } & Green algae & 2014-05-14 & 6 & 0.216 \\
\hline & & 2014-06-18 & 9 & 0.098 \\
\hline & & $2014-07-29$ & 9 & 0.418 \\
\hline & & 2014-08-21 & 14 & 1.033 \\
\hline & & 2014-09-17 & 6 & 0.479 \\
\hline & & 2014-10-21 & 3 & 0.009 \\
\hline \multirow[t]{6}{*}{ Cyanophyta } & Blue-green algae & 2014-05-14 & 3 & 0.108 \\
\hline & & 2014-06-18 & 79 & 0.856 \\
\hline & & 2014-07-29 & 45 & 2.092 \\
\hline & & 2014-08-21 & 70 & 5.167 \\
\hline & & 2014-09-17 & 63 & 5.027 \\
\hline & & 2014-10-21 & 1 & 0.003 \\
\hline \multirow[t]{7}{*}{ Haptophyta/cryptophyta } & Flagellates & 2014-05-14 & 3 & 0.108 \\
\hline & & 2014-06-18 & 3 & 0.033 \\
\hline & & 2014-07-29 & 5 & 0.232 \\
\hline & & 2014-08-21 & 8 & 0.591 \\
\hline & & 2014-09-17 & 15 & 1.197 \\
\hline & & 2014-10-21 & 94 & 0.291 \\
\hline & & Pearl Lake & & \\
\hline \multirow[t]{6}{*}{ Diatoms/crysophyta } & Diatoms & $2014-05-27$ & 1 & 0.004 \\
\hline & & 2014-06-24 & 0 & 0.000 \\
\hline & & 2014-07-23 & 7 & 0.111 \\
\hline & & 2014-08-27 & 9 & 0.112 \\
\hline & & 2014-09-22 & 10 & 0.186 \\
\hline & & 2014-10-27 & 17 & 0.243 \\
\hline \multirow[t]{6}{*}{ Chlorophyta } & Green algae & 2014-05-27 & 34 & 0.136 \\
\hline & & 2014-06-24 & 8 & 0.080 \\
\hline & & 2014-07-23 & 4 & 0.064 \\
\hline & & 2014-08-27 & 20 & 0.248 \\
\hline & & 2014-09-22 & 25 & 0.465 \\
\hline & & $2014-10-27$ & 13 & 0.186 \\
\hline \multirow[t]{6}{*}{ Cyanophyta } & Blue-green algae & 2014-05-27 & 6 & 0.024 \\
\hline & & 2014-06-24 & 91 & 0.910 \\
\hline & & $2014-07-23$ & 85 & 1.353 \\
\hline & & 2014-08-27 & 157 & 1.946 \\
\hline & & 2014-09-22 & 35 & 0.651 \\
\hline & & $2014-10-27$ & 11 & 0.157 \\
\hline \multirow[t]{6}{*}{ Haptophyta/cryptophyta } & Flagellates & $2014-05-27$ & 59 & 0.237 \\
\hline & & 2014-06-24 & 1 & 0.010 \\
\hline & & $2014-07-23$ & 2 & 0.032 \\
\hline & & 2014-08-27 & 10 & 0.124 \\
\hline & & 2014-09-22 & 30 & 0.558 \\
\hline & & $2014-10-27$ & 57 & 0.814 \\
\hline
\end{tabular}


Publishing support provided by: Rolla Publishing Service Center

For more information concerning this publication, contact: Director, USGS Minnesota Water Science Center 2280 Woodale Drive

Mounds View, Minnesota 55112

(763) 783-3100

Or visit the Minnesota Water Science Center website at: https://mn.water.usgs.gov/ 



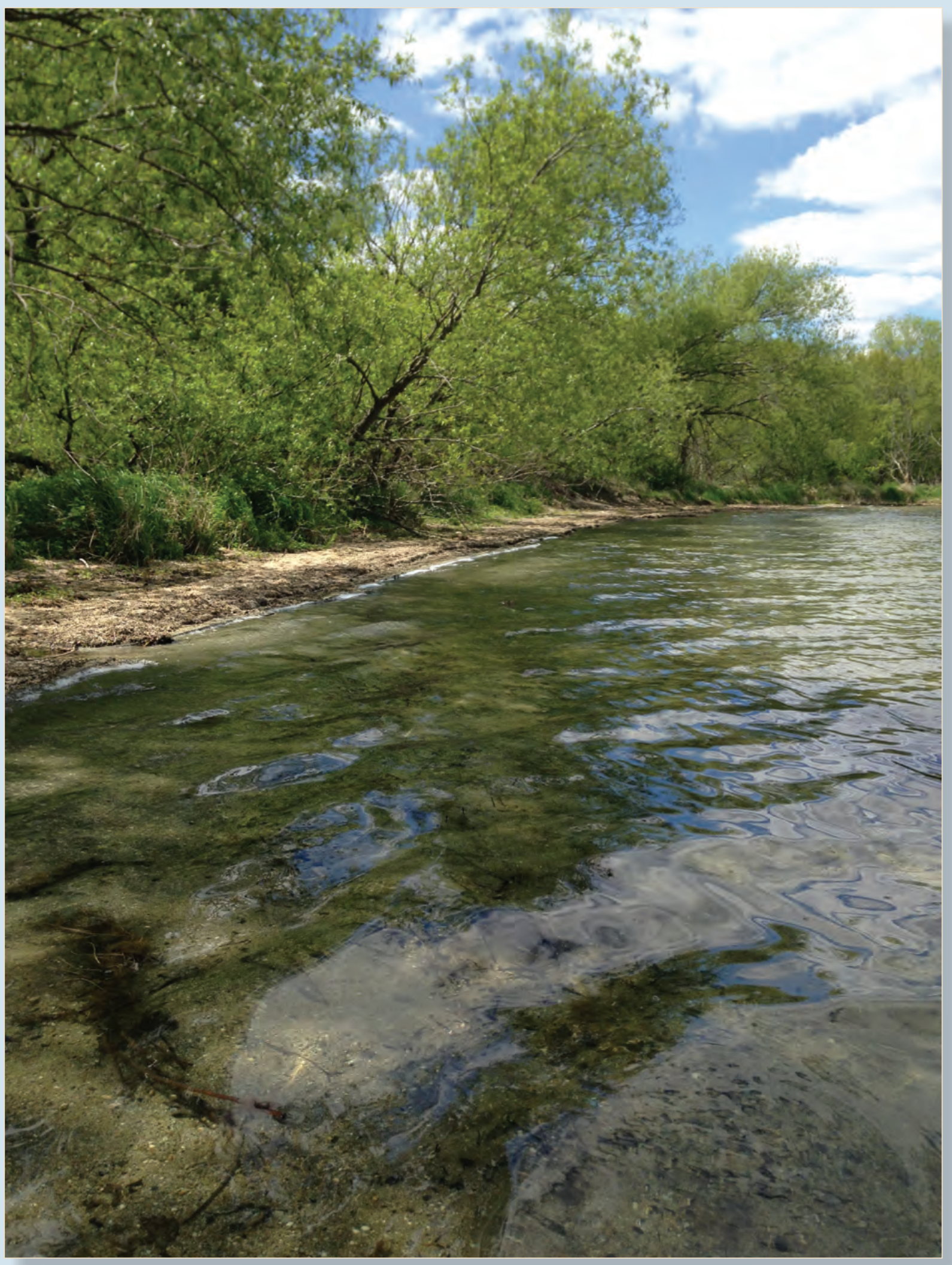

